\title{
Potash-A Global Overview of Evaporite-Related Potash Resources, Including Spatial Databases of Deposits, Occurrences, and Permissive Tracts
}

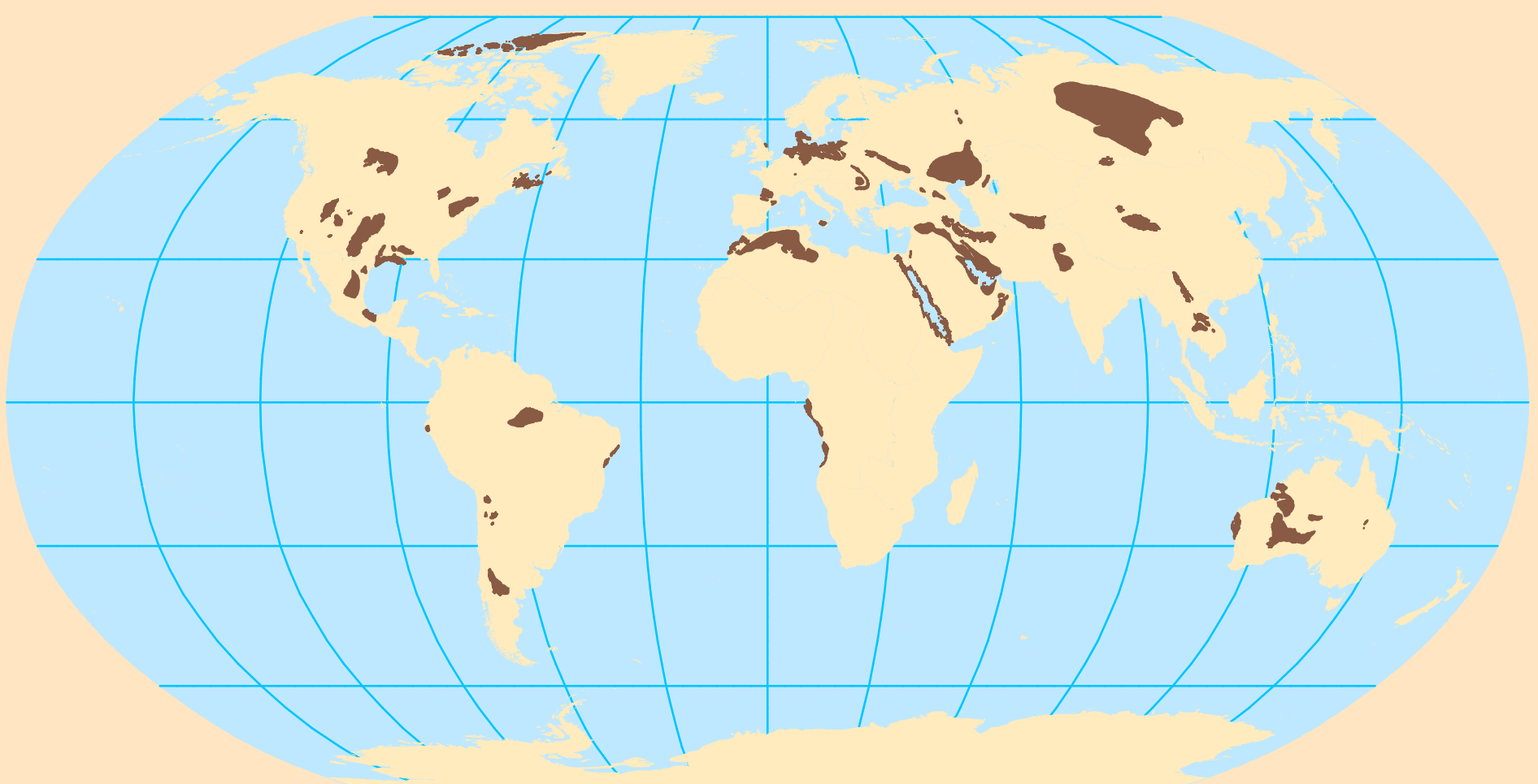

Prepared in cooperation with the Saskatchewan Geological Survey, the Polish Geological Institute, the Nova Scotia Department of Natural Resources, the Bureau de Recherches Géologiques et Minières, the Bundesanstalt für Geowissenschften und Rohstoffe, and the Coordinating Committee for Geoscience Programmes in East and Southeast Asia

Scientific Investigations Report 2010-5090-S 
This page intentionally left blank. 


\section{Global Mineral Resource Assessment}

Michael L. Zientek, Jane M. Hammarstrom, and Kathleen M. Johnson, editors

\section{Potash-A Global Overview of Evaporite-Related Potash Resources, Including Spatial Databases of Deposits, Occurrences, and Permissive Tracts}

By Greta J. Orris, Mark D. Cocker, Pamela Dunlap, Jeff Wynn, Gregory T. Spanski, Deborah A. Briggs, and Leila Gass with contributions from James D. Bliss, Karen S. Bolm, Chao Yang, Bruce R. Lipin, Steve Ludington, Robert J. Miller, and Miroslaw Slowakiewicz

Prepared in cooperation with the Saskatchewan Geological Survey, the Polish Geological Institute, the Nova Scotia Department of Natural Resources, the Bureau de Recherches Géologiques et Minières, the Bundesanstalt für Geowissenschften und Rohstoffe, and the Coordinating Committee for Geoscience Programmes in East and Southeast Asia

Scientific Investigations Report 2010-5090-S 


\title{
U.S. Department of the Interior SALLY JEWELL, Secretary
}

\section{U.S. Geological Survey \\ Suzette M. Kimball, Acting Director}

\author{
U.S. Geological Survey, Reston, Virginia: 2014
}

For more information on the USGS - the Federal source for science about the Earth, its natural and living resources, natural hazards, and the environment, visit http://www.usgs.gov or call 1-888-ASK-USGS.

For an overview of USGS information products, including maps, imagery, and publications, visit http://www.usgs.gov/pubprod

To order this and other USGS information products, visit http://store.usgs.gov

Any use of trade, firm, or product names is for descriptive purposes only and does not imply endorsement by the U.S. Government.

Although this information product, for the most part, is in the public domain, it also may contain copyrighted materials as noted in the text. Permission to reproduce copyrighted items must be secured from the copyright owner.

Suggested citation:

Orris, G.J., Cocker, M.D., Dunlap, P., Wynn, Jeff, Spanski, G.T., Briggs, D.A., and Gass, L., with contributions from Bliss, J.D., Bolm, K.S., Yang, C., Lipin, B.R., Ludington, S., Miller, R.J., and Slowakiewicz, M., 2014, Potash-A global overview of evaporite-related potash resources, including spatial databases of deposits, occurrences, and permissive tracts: U.S. Geological Survey Scientific Investigations Report 2010-5090-S, 76 p., and spatial data, http://dx.doi.org/10.3133/sir20105090S.

ISSN 2328-0328 (online) 


\section{Contents}

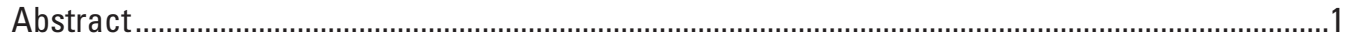

Chapter 1. Potash—Uses, Active Mines, and Recent Exploration.................................................

Chapter 2. Potash Deposits and Occurrences in Evaporite Settings of the World.........................9

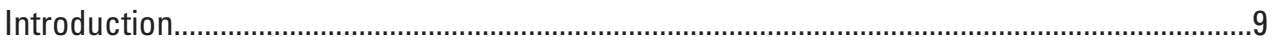

Site Information—Data Compilation, Classification, and Locations .......................................9

Geology and Geography of the Potash Deposits and Occurrences Database .......................11

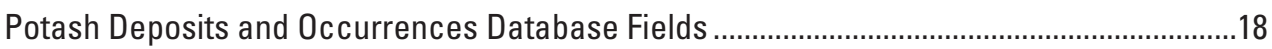

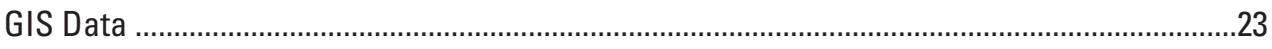

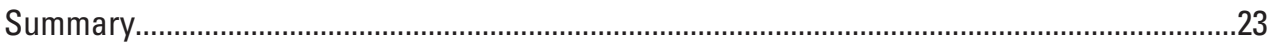

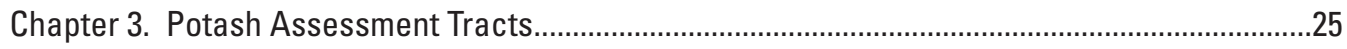

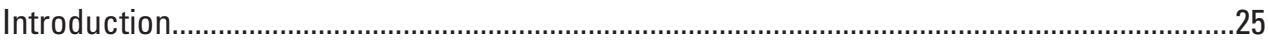

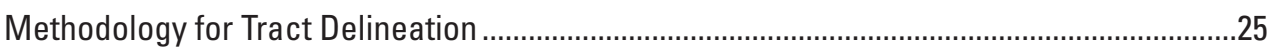

Geology, Geography, and Mineral Economics of Potash Tracts...........................................28

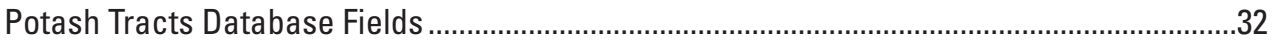

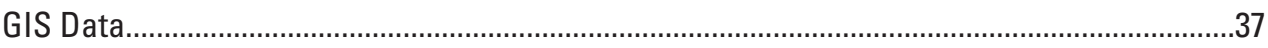

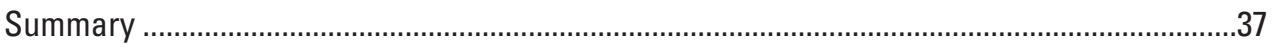

Chapter 4. Spatial Databases for Evaporite-Related Potash Deposits, Occurrences, and

Permissive Tracts Around the World ..............................................................................39

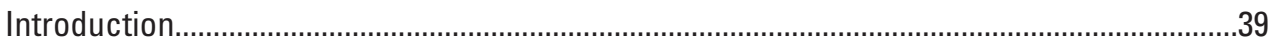

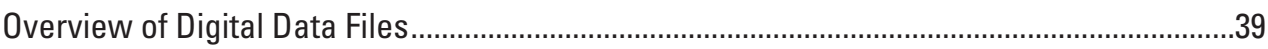

Spatial Databases, Data Files, and Relationship Classes ..................................................39

Map Document Files, Layer Files, and Graphics Files .....................................................42

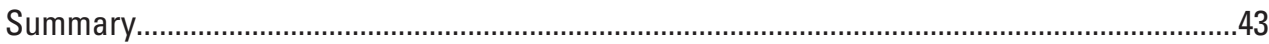

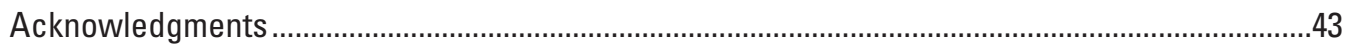

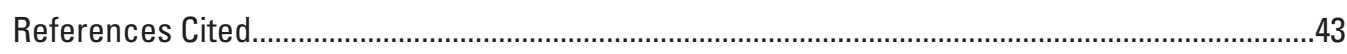

Appendix A. Summary Descriptive Model of Stratabound Potash-Bearing Salt Deposits............52

Appendix B. Summary Descriptive Model of Halokinetic Potash-Bearing Salt Deposits..............59

Appendix C. Glossary of Terms Used in the Description of Evaporites .........................................66

Appendix D. Abbreviations Used in the Potash Geodatabases.....................................................70

Appendix E. Digital Data Files...............................................................................................

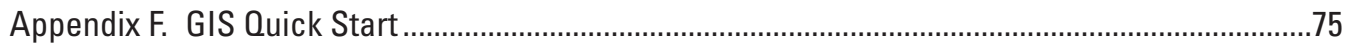




\section{Figures}

1-1. Map showing active potash mines or producing areas......................................................4

2-1. Map showing distribution of potash deposits and occurrences classified as the stratabound potash-bearing salt deposit type.

2-2. Map showing distribution of potash deposits and occurrences classified as the halokinetic potash-bearing salt or mixed stratabound and halokinetic

potash-bearing salt deposit types

2-3. Map showing distribution of potash deposits and occurrences classified as the potash-bearing brine deposit type.

2-4. Graph showing distribution of basin types within the potash deposits and occurrences database.

2-5. Graph showing age distribution, by period, within the potash deposits and occurrences database.

2-6. Map showing paleogeographic distribution of Cisuralian-age potash deposits of Eastern Europe and their relation to the Paleotethys Ocean and Pangea 17

3-1. Map showing locations of 84 potash tracts delineated during this study .......................26

3-2. Graph showing distribution of deposit type classifications for 84 potash tracts ............28

3-3. Map showing distribution of tracts by deposit type ...........................................................29

3-4. Map showing cumulative known potash ore resources for selected potash tracts ......31

3-5. Graph showing distribution of basin type classifications for 84 potash tracts ...............32

A1. Map showing locations of basins with stratabound potash-bearing salt deposits and mixed stratabound and halokinetic potash-bearing salt deposits

B1. Map showing locations of basins with halokinetic potash-bearing salt deposits and mixed stratabound and halokinetic potash-bearing salt deposits 


\section{Tables}

1-1. Partial list of potash exploration projects and areas since 2000 .......................................5

1-2. Potash projects reported to be under development since 2004 ........................................7

2-1. Potash deposit types used in this study......................................................................

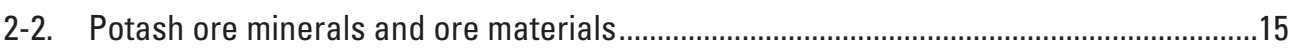

2-3. Relation between data field terms used in chapters 2 and 3 of this report and

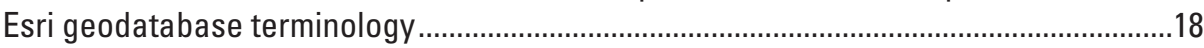

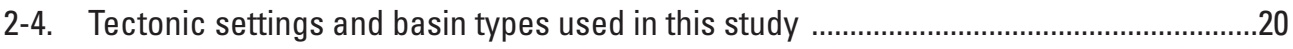

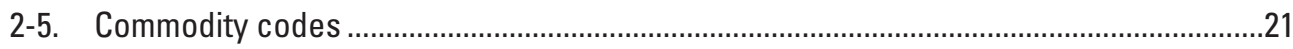

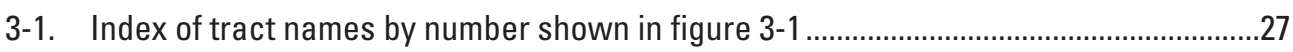

3-2. United Nations regional codes used for Coded_IDs in the global potash database .......32

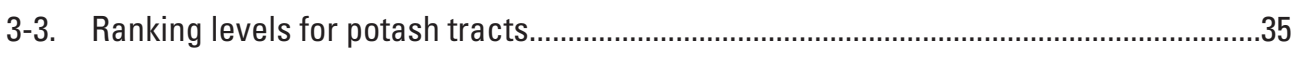

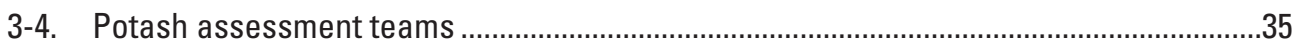

3-5. Additional attribute fields for categorization of available graphics..................................36

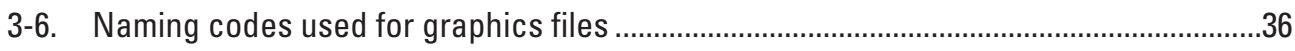

4-1. GIS terminology and concepts used in this report.......................................................40

4-2. Description of feature classes in the feature dataset Evap_Potash ...............................40

4-3. Description of supplemental non-spatial data tables and relationship classes in the file geodatabase USGS_Global_Potash.gdb ........................................................41

4-4. Description of data files exported from the feature classes Potash_Deposits and

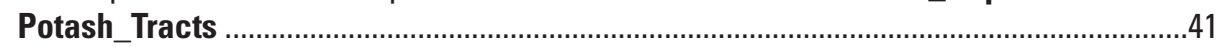

4-5. Layer files for deposits and occurrences in the feature class Potash_Deposits ...........42

4-6. Layer files for permissive tracts in the feature class Potash_Tracts ............................42

A1. Ore minerals and common accessory and gangue minerals in stratabound

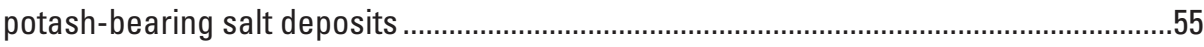

B1. Ore minerals and common accessory and gangue minerals in halokinetic

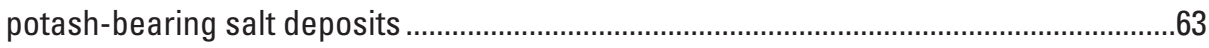

D1. List of abbreviations used in the potash geodatabases .................................................70

E1. List and description of spatial databases and associated files in the compressed archive file PotashGIS.zip .........................................................................................

E2. List and description of tabular data files in the compressed archive PotashXL.zip .......74

E3. List and description of spatial data and associated files in the compressed archive PotashKML.zip . 


\section{Conversion Factors}

Inch/Pound to SI

\begin{tabular}{lcl}
\hline \multicolumn{1}{c}{ Multiply } & By & \multicolumn{1}{c}{ To obtain } \\
\hline foot $(\mathrm{ft})$ & Length & \\
mile (mi) & 0.3048 & meter $(\mathrm{m})$ \\
yard (yd) & 1.609 & kilometer $(\mathrm{km})$ \\
& 0.9144 & meter $(\mathrm{m})$ \\
\hline acre & Area & \\
acre & 0.4047 & hectare $($ ha) \\
square mile $\left(\mathrm{mi}^{2}\right)$ & 0.004047 & square kilometer $\left(\mathrm{km}^{2}\right)$ \\
square mile $\left(\mathrm{mi}^{2}\right)$ & 259.0 & hectare $($ ha) \\
\hline & 2.590 & square kilometer $\left(\mathrm{km}^{2}\right)$ \\
\hline ounce, troy (troy oz) & Mass & \\
ounce, troy (troy oz) & 31.015 & gram $(\mathrm{g})$ \\
ton, short $(\mathrm{T})(2,000 \mathrm{lb})$ & 0.0000311 & megagram $(\mathrm{Mg})$ \\
\hline
\end{tabular}

SI to Inch/Pound

\begin{tabular}{lcl}
\hline \multicolumn{1}{c}{ Multiply } & By & To obtain \\
\hline meter $(\mathrm{m})$ & Length & \\
kilometer $(\mathrm{km})$ & 3.281 & foot $(\mathrm{ft})$ \\
meter $(\mathrm{m})$ & 0.6214 & mile $(\mathrm{mi})$ \\
& 1.094 & yard (yd) \\
\hline hectare $($ ha) & Area & acre \\
square kilometer $\left(\mathrm{km}^{2}\right)$ & 2.471 & acre \\
hectare (ha) & 247.1 & square mile $\left(\mathrm{mi}^{2}\right)$ \\
square kilometer $\left(\mathrm{km}^{2}\right)$ & 0.003861 & square mile $\left(\mathrm{mi}^{2}\right)$ \\
\hline & 0.3861 & \\
\hline gram $(\mathrm{g})$ & Mass & ounce, troy $($ troy oz) \\
megagram $(\mathrm{Mg})$ & 0.03215 & ton, short $(\mathrm{T})(2,000 \mathrm{lb})$ \\
\hline
\end{tabular}

Other conversions used in this report

\begin{tabular}{lcl}
\hline \multicolumn{1}{c}{ Multiply } & By & \multicolumn{1}{c}{ To obtain } \\
\hline metric ton $(\mathrm{t})$ & 1 & megagram $(\mathrm{Mg})$ \\
percent $(\%)$ & 10,000 & parts per million $(\mathrm{ppm})$ or grams \\
& & per metric ton $(\mathrm{g} / \mathrm{t})$ \\
\hline
\end{tabular}




\title{
Potash-A Global Overview of Evaporite-Related Potash Resources, including Spatial Databases of Deposits, Occurrences, and Permissive Tracts
}

\author{
By Greta J. Orris ${ }^{1}$ Mark D. Cocker1, Pamela Dunlap', Jeff Wynn², Gregory T. Spanski3 , Deborah A. Briggs ${ }^{4}$, \\ and Leila Gass ${ }^{1}$
}

\section{Abstract}

Potash is mined worldwide to provide potassium, an essential nutrient for food crops. Evaporite-hosted potash deposits are the largest source of salts that contain potassium in water-soluble form, including potassium chloride, potassium-magnesium chloride, potassium sulfate, and potassium nitrate. Thick sections of evaporitic salt that form laterally continuous strata in sedimentary evaporite basins are the most common host for stratabound and halokinetic potashbearing salt deposits. Potash-bearing basins may host tens of millions to more than 100 billion metric tons of potassium oxide $\left(\mathrm{K}_{2} \mathrm{O}\right)$. Examples of these deposits include those in the Elk Point Basin in Canada, the Pripyat Basin in Belarus, the Solikamsk Basin in Russia, and the Zechstein Basin in Germany.

This report describes a global, evaporite-related potash deposits and occurrences database and a potash tracts database. Chapter 1 summarizes potash resource history and use. Chapter 2 describes a global potash deposits and occurrences database, which contains more than 900 site records. Chapter 3 describes a potash tracts database, which contains 84 tracts with geology permissive for the presence of evaporite-hosted potash resources, including areas with active evaporite-related potash production, areas with known mineralization that has not been quantified or exploited, and areas with potential for undiscovered potash resources. Chapter 4 describes geographic information system (GIS) data files that include (1) potash deposits and occurrences data, (2) potash tract data, (3) reference databases for potash deposit and tract data, and (4) representative graphics of geologic features related to potash tracts and deposits. Summary descriptive models for stratabound potash-bearing salt and halokinetic potash-bearing salt are included in appendixes A and B, respectively. A glossary of salt- and potash-related terms is contained in appendix $\mathrm{C}$ and a list of database abbreviations is given in appendix D. Appendix E describes GIS data files, and appendix $\mathrm{F}$ is a guide to using the geodatabase.

${ }^{1}$ U.S. Geological Survey, Tucson, Arizona, United States.

${ }^{2}$ U.S. Geological Survey, Vancouver, Washington, United States.

${ }^{3}$ U.S. Geological Survey, Denver, Colorado, United States.

${ }^{4}$ U.S. Geological Survey, Spokane, Washington, United States. 
This page intentionally left blank. 


\title{
Chapter 1. Potash-Uses, Active Mines, and Recent Exploration
}

\author{
By Greta J. Orris ${ }^{1}$ and Mark D. Cocker ${ }^{1}$
}

The term "potash" denotes a variety of mined and manufactured salts, all of which contain the element potassium in water-soluble form (Jasinski, 2011a) and is used by industry to refer to potassium chloride, as well as potassium sulfate, nitrate, and oxide (Neuendorf and others, 2005). The term "potash" is also used as a synonym for a wide variety of potassium-rich minerals and rocks. Potash resources, on a global scale, most commonly occur as potash salts in evaporite sequences in pre-Quaternary sedimentary basins. These basins had limited siliciclastic input, formed in arid climates, and had restricted seawater access that nonetheless allowed periodic seawater replenishment (Hardie, 1991; Warren, 2010).

In 2010, world potash production was about 33 million metric tons of $\mathrm{K}_{2} \mathrm{O}$ equivalent (Jasinski, 2011a). Canada is the largest producer of potash $\left(9.5\right.$ million metric tons $\mathrm{K}_{2} \mathrm{O}$ equivalent in 2010), followed by Russia, Belarus, China,
Germany, Israel, and Jordon (fig. 1-1; Jasinski, 2011b). All of these countries produced at least 1 million metric tons of $\mathrm{K}_{2} \mathrm{O}$ equivalent in 2010, whereas production from other countries was less than 1 million metric tons each.

Demand for potash is driven primarily by its use in fertilizers for food and biofuel production. An expanding global population, changing diets, and decreasing amounts of arable land have increased the need for fertilizer minerals, including potash (Magen, 2010a,b). This increase in demand has led to higher prices and interest in new potash sources. Over the past 5-10 years, exploration for potash deposits has been reported in more than 40 locations (table 1-1) and development has begun in at least 20 locations (table 1-2). This recent exploration and development provides new data on the global occurrence and geology of potash in addition to data available since potash exploration efforts of the 1960s and early 1970s.

${ }^{1}$ U.S. Geological Survey, Tucson, Arizona, United States. 


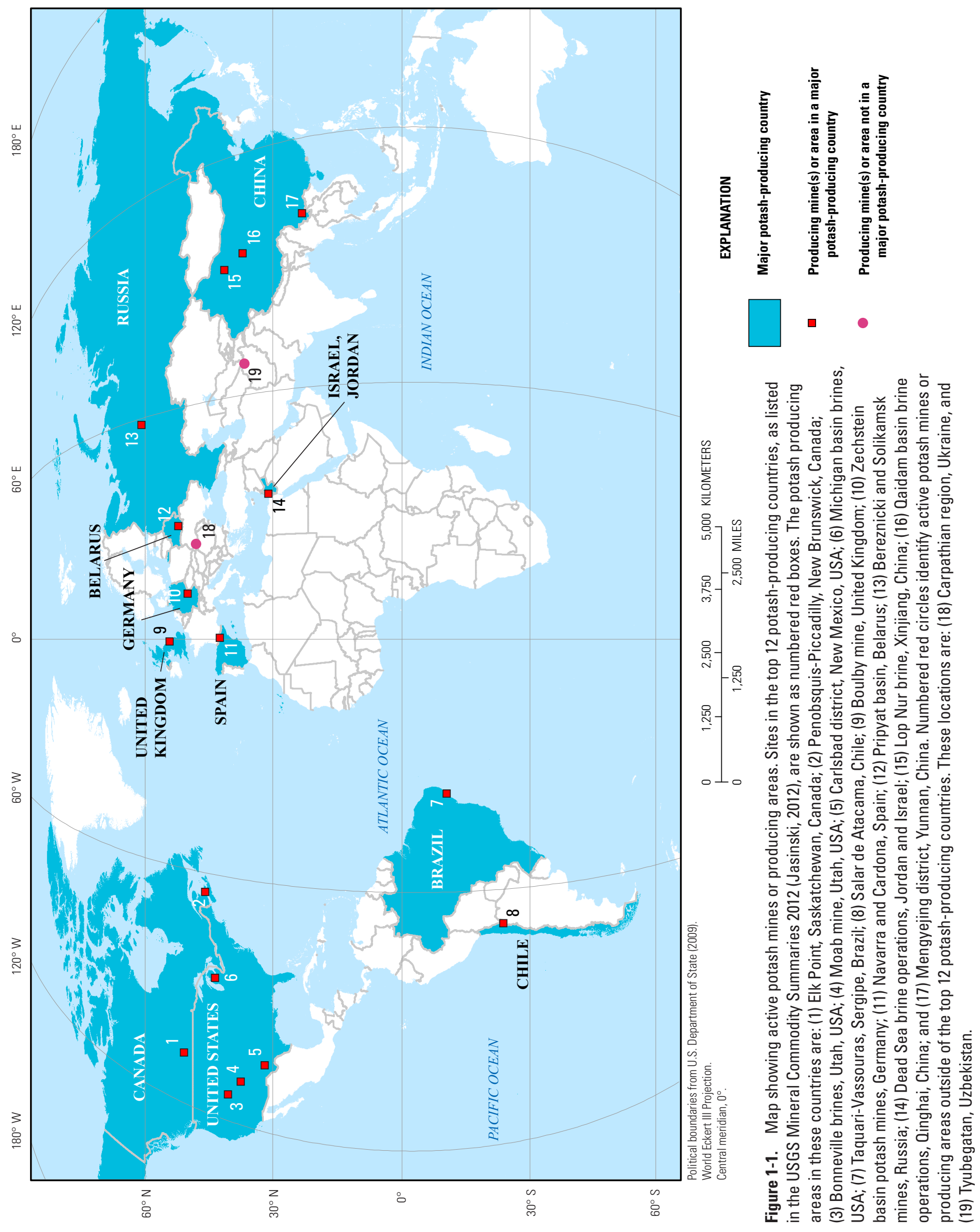


Table 1-1. Partial list of potash exploration projects and areas since 2000.

[*, exploration target is continental closed basin brine]

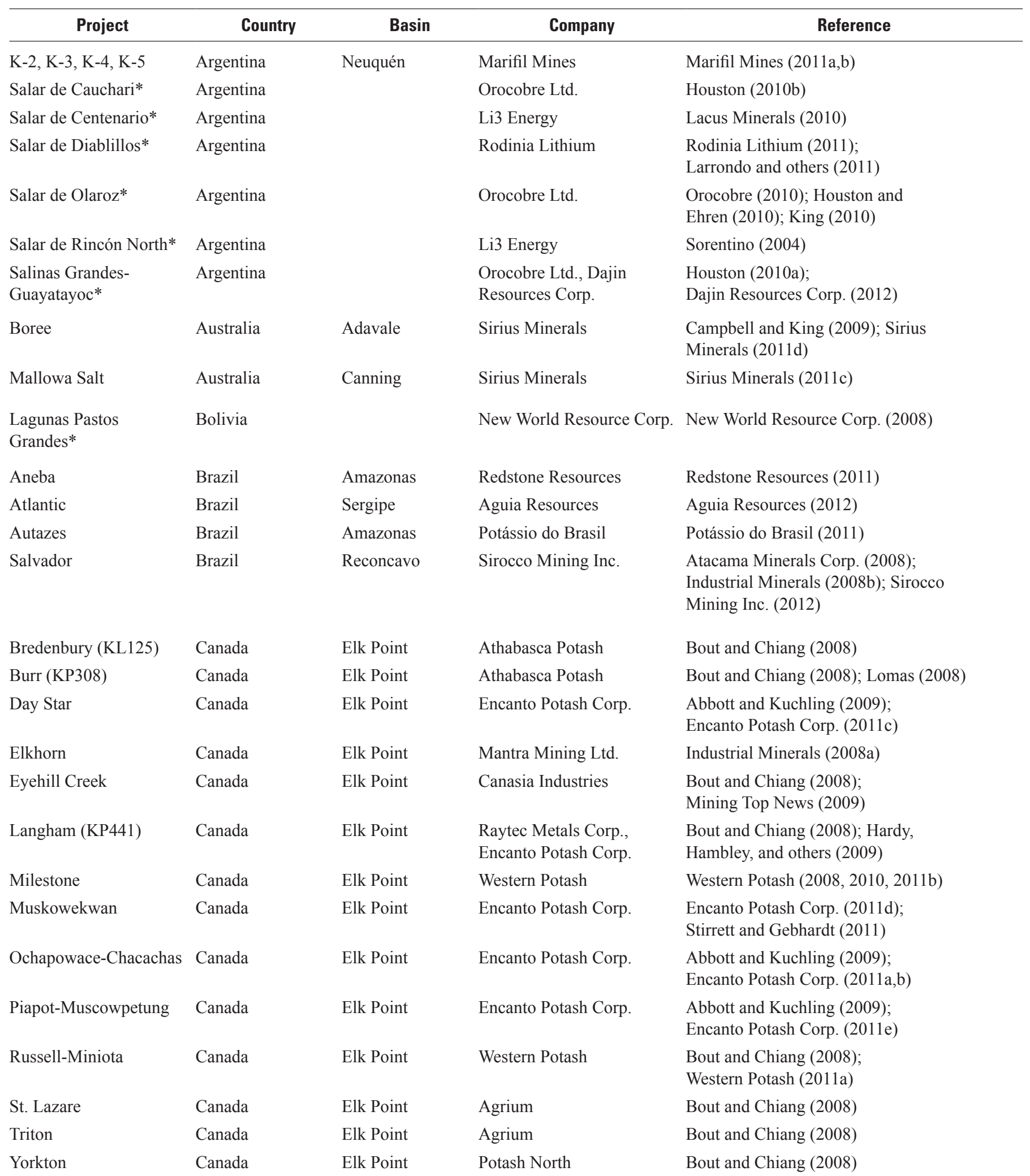


Table 1-1. Partial list of potash exploration projects and areas since 2000._Continued

$\left[{ }^{*}\right.$, exploration target is continental closed basin brine $]$

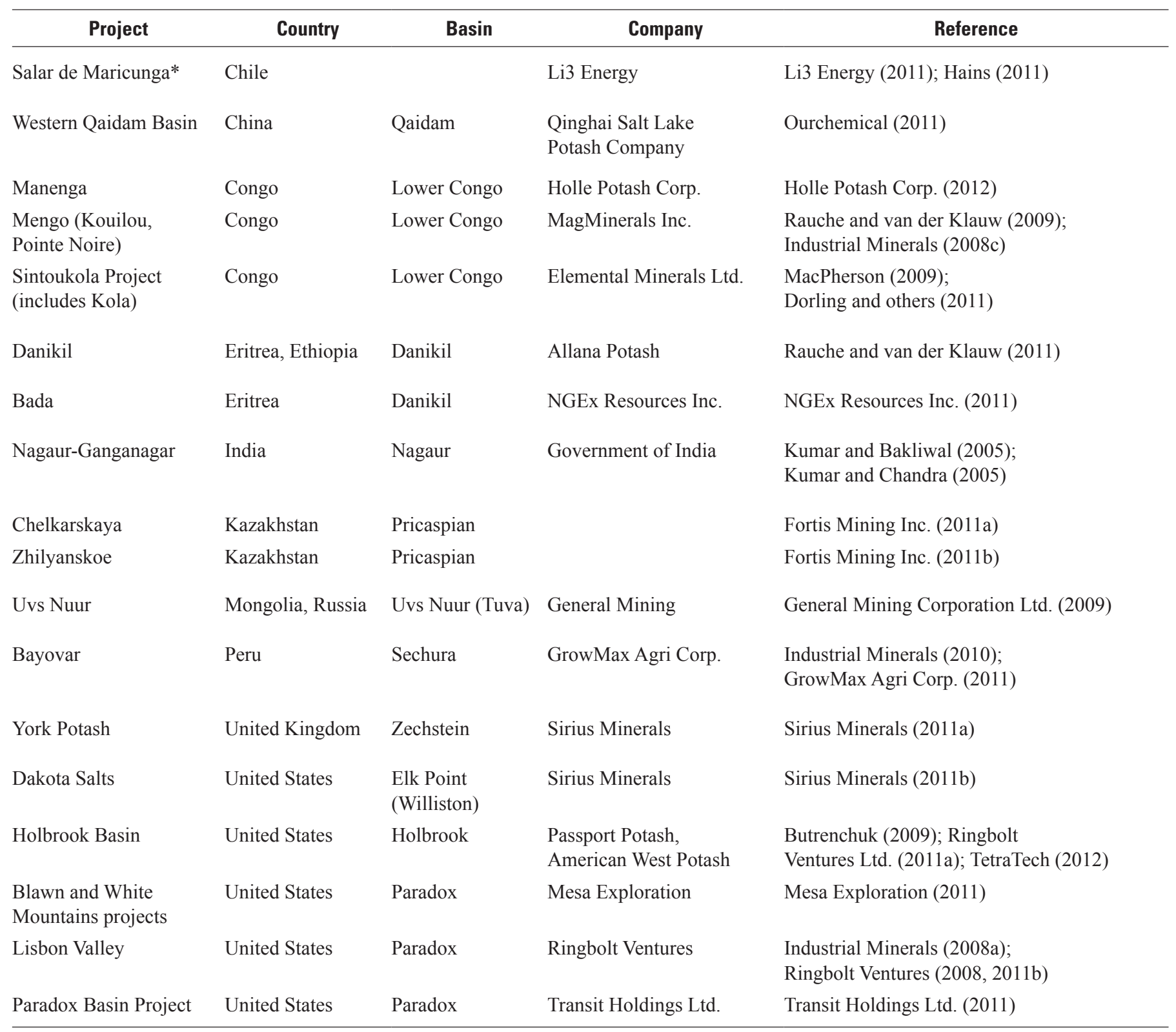


Table 1-2. Potash projects reported to be under development since 2004.

[*, development target is continental closed brine $]$

\begin{tabular}{|c|c|c|c|c|}
\hline Project & Country & Tract(s) & Company & Reference \\
\hline Rincón, Salar de* & Argentina & Rincón & $\begin{array}{l}\text { Admiralty Resources; } \\
\text { Sentient Group }\end{array}$ & $\begin{array}{l}\text { Sorentino (2004); } \\
\text { Pavlovic and Fowler (2004) }\end{array}$ \\
\hline Rio Colorado $^{1}$ & Argentina & Neuquén & Vale S.A. & Spinetto and Gonzalez (2013) \\
\hline Berezovsky mine $(\text { Starobin } 6)^{2}$ & Belarus & Pripyat & Belaruskali & $\begin{array}{l}\text { Belaruskali (2011); } \\
\text { Interfax America Inc. (2012) }\end{array}$ \\
\hline Darasinsky & Belarus & Pripyat & Belaruskali & $\begin{array}{l}\text { Foreign Policy and } \\
\text { Security Research Center (2011) }\end{array}$ \\
\hline Krasnoslobodsky $(\text { Starobin } 5)^{3}$ & Belarus & Pripyat & Belaruskali & Belaruskali (2011); Moore (2010) \\
\hline Nezhinsky & Belarus & Pripyat & Belaruskali & $\begin{array}{l}\text { Foreign Policy and } \\
\text { Security Research Center (2011) }\end{array}$ \\
\hline Projecto Carnalita da Vale & Brazil & Sergipe & Petrobras, Vale & Pinheiro (2008) \\
\hline Jansen & Canada & $\begin{array}{l}\text { Patience Lake, } \\
\text { Belle Plaine }\end{array}$ & BHP Billiton & BHP Billiton $(2010,2011)$ \\
\hline Legacy (Findlater, KP289) & Canada & $\begin{array}{l}\text { Patience Lake, } \\
\text { Belle Plaine, } \\
\text { Esterhazy }\end{array}$ & $\mathrm{K}+\mathrm{S}$ Potash Canada & $\begin{array}{l}\text { Bout and Chiang (2008); } \\
\text { Hardy, Halabura, and Shewfelt (2009); } \\
\text { K+S Potash Canada (2011) }\end{array}$ \\
\hline Picadilly (extension to Penobsquis) & Canada & Maritimes A & $\begin{array}{l}\text { Potash Corporation of } \\
\text { Saskatchewan }\end{array}$ & Moore and others (2008) \\
\hline Rocanville (extension) & Canada & Esterhazy & $\begin{array}{l}\text { Potash Corporation of } \\
\text { Saskatchewan }\end{array}$ & Moore and others (2010) \\
\hline Wynyard (Quill Lakes) & Canada & $\begin{array}{l}\text { Patience Lake, Belle } \\
\text { Plaine, Esterhazy }\end{array}$ & Karnalyte Resources & Molavi and others (2010) \\
\hline Mengo (Pointe Noire) & Congo & Lower Congo North & MagIndustries & Northern Miner (2009) \\
\hline Satimola & Kazakhstan & Pricaspian & Satimola, Ltd. & Agapito Associates (2011) \\
\hline Dong Tai & Lao PDR & Sakhon Nakhon & Sino-Agri & Wang (2010) \\
\hline Thongmang (Vientiane) & Lao PDR & Sakhon Nakhon & $\begin{array}{l}\text { China-Laos Minerals } \\
\text { Development and } \\
\text { Investment Corporation }\end{array}$ & Chinese Academy of Sciences (2011) \\
\hline Gremyachinsk & Russia & Pricaspian & EuroChem & $\begin{array}{l}\text { Chemical Business Newsbase (2011); } \\
\text { EuroChem (2010) }\end{array}$ \\
\hline Ust-Jaiwa & Russia & Solikamsk & Uralkali & CDM (2011) \\
\hline Karlyuk (Garlyk) & Turkmenistan & Gissar & Belarusian Potash Co. & Bromby (2011); Blagov (2010) \\
\hline Tyubegatan ${ }^{3}$ & Uzbekistan & Gissar & Uzkhimprom & Safirova (2012) \\
\hline
\end{tabular}

${ }^{1}$ Project work suspended in December 2012.

${ }^{2}$ Mine reported to be commissioned in June 2012 (Interfax America Inc., 2012).

${ }^{3}$ Mine in production in 2010. 
This page intentionally left blank. 


\title{
Chapter 2. Potash Deposits and Occurrences in Evaporite Settings of the World
}

\author{
By Greta J. Orris', Mark D. Cocker ${ }^{1}$, and Pamela Dunlap ${ }^{1}$
}

\section{Introduction}

The global potash inventory described in this chapter documents the geologic occurrence of (1) evaporite-related potassium mineralization, and (2) naturally occurring brines enriched in potassium. The term "potash," as used in this report, refers to potassium-bearing minerals, ores, and processed products. Data on the distribution of known deposits and occurrences, and their geologic settings, are an integral part of a geologically based evaluation of undiscovered mineral resources. The geology and distribution of known potash occurrences aid us in understanding the factors that control mineralization and in identifying areas with potential for undiscovered resources. Known deposits also serve as analogs for undiscovered resources because their size and composition are likely similar to those of undiscovered deposits.

This compilation of known potash deposits and occurrences is part of a U.S. Geological Survey (USGS)-led global mineral resource assessment for undiscovered potash (Schulz and Briskey, 2003; Hammarstrom and others, 2010). As part of this report, these data and other spatial data are made available as Esri geodatabase files (see chapter 4), Google Earth Keyhole Markup Language (KML) files, and as Excel files for those without access to ArcGIS. No other publicly available database of potash deposits and occurrences with plottable locations is known to exist, although some summaries of known occurrences, such as Garrett (1996), are published. This chapter describes the potash deposits and occurrences database and contents of database fields, as well as how data were collected. A short summary of potash site data is also included.

\section{Site Information-Data Compilation, Classification, and Locations}

The potash deposits and occurrences database presented here contains geological information from evaporite-related potash mineral occurrences and potassium-enriched brines at 981 sites. An initial data compilation was completed between 2001 and 2005; this compilation was expanded and updated from 2008 through 2011 as a renewed interest in potash led to an exploration boom.

Scientific and technical literature describing the local geologic setting of potassium-bearing rocks and brines is available for some potash deposits and occurrences; however, geologic information for other sites must be inferred from regional-scale geology or from analysis of mineral-resource development activity (for example, maps of lease areas or mine information). To be comprehensive, we include records for all types of sites associated with evaporite-related potash mineralization or potassium-enriched brines that provide insight on geologic characteristics. These sites include features as general as a sedimentary basin or as specific as a drill hole location. Site-specific information is included in the database where available.

Geologic, location, and reference data comprise the core of the potash deposits and occurrences database. This information was assembled from earlier compilations, published reports, company Web sites and press releases, maps, extremely limited site visits, knowledgeable contacts, and a variety of other sources. For many individual sites, geologic data were compiled from multiple sources.

Information is included in the database as reported, with the following exceptions: (1) the site is located in a delineated tract (see chapter 3) resulting in standardization of some fields for records within a given tract; (2) data from two or more sources conflict and authors chose either the most correct or up-to-date information or noted the conflict in the database; and (3) ages were converted to those defined on the International Stratigraphic Chart (International Commission on Stratigraphy, 2010); and, where age determinations are not made, conflicting information is noted in the database. Some information in the database describes only the geology of an area where data are not available for specific deposits or occurrences. 
Most sites in the database are classified as a specific deposit type (table 2-1) such as stratabound potash-bearing salt (appendix A), halokinetic potash-bearing salt (appendix B), or potash-bearing brine (Orris, 2011). Sites lacking data needed for specific classification were handled as noted in the description of the Deposit Type data field later in this chapter. In this report, halokinetic structures include diapirs, salt walls, pillows, and other structurally deformed salt accumulations that originated as stratabound deposits, but were subsequently deformed by faults, regional deformation, and (or) lithostatic loading. Some database records correspond to potassiumbearing brines found in playas or salars (Orris, 2011) or as intraformational brines.

Location data are essential to developing geospatial databases. Obtaining coordinates for each mine, deposit, or occurrence, accurate enough to display locations at 1:1,000,000-scale, was a challenge. For example, most source information is 20 years or older in age and does not report site coordinates; location information is commonly only descriptive or based on legal descriptions. Where coordinates are reported, they are typically rounded to the nearest five minutes. Also, many potash mines and deposits cover very large areas, and are therefore not best represented by point locations. Property and deposit boundaries could be digitized, but these data are rare and storage of non-point locational data poses its own challenges for a compilation of this breadth.

In this assessment, single points (in latitude-longitude coordinates) representing approximate centers of potash site areas were selected to represent areally extensive potash deposits in the database. For many potash sites in the database, latitudes and longitudes were determined from published maps or tables, or approximately located based on the proximity of nearby towns or geographic features. Latitudes and longitudes for many towns and geographic features were determined using the Geographic Names Information System of the U.S. Geological Survey ${ }^{2}$ for sites in the United States. Digital locations for foreign sites were approximated using the Geographic Names Server of the National Geospatial-Intelligence Agency (DOD) ${ }^{3}$ in conjunction with location descriptions.

In some instances, more precise site locations were determined by using Google Earth to identify above-ground mining and processing facilities, mine dumps and tailings, or rarely, visible geologic and geographic features associated with deposits, such as salt domes and lakes. Because evaporitic salts, especially potash-bearing salts, are highly

Table 2-1. Potash deposit types used in this study.

\begin{tabular}{clc}
\hline \multicolumn{1}{c}{ Deposit type } & \multicolumn{1}{c}{ Description $^{\text {Code }}{ }^{\mathbf{1}}$} \\
\hline Stratabound potash-bearing salt & $\begin{array}{l}\text { Stratabound potash deposits hosted by relatively flat-lying and undeformed salt } \\
\text { rock and related basin-wide evaporite deposits (see appendix A). }\end{array}$ \\
Halokinetic potash-bearing salt & Potash deposits in salt rock and associated evaporites that have been deformed
\end{tabular}
by salt flow into salt domes and other salt structures. Within these structures, the potash mineralization is commonly disrupted and deformed with repeated, thickened, and (or) thinned bedding, or even the total loss of potash mineralization (see appendix B).

Mixed stratabound and halokinetic potash-bearing salt

Potash-bearing brine

Evaporite

Not determined ${ }^{2}$
Potash deposits with characteristics transitional between stratabound potash-bearing salt and halokinetic potash-bearing salt or with characteristics of both types.

Near-surface brine-dominated systems in closed continental basins enriched in potassium and other commodities; commonly Pliocene to Quaternary in age (Orris, 2011).

Potash deposits where there is insufficient data available to determine a specific deposit type, but where the mineralization is known to be evaporite-related.

Deposit type could not be determined, but is believed to be evaporite-related.
$\mathrm{mxK}$

brK

unK

\footnotetext{
${ }^{1}$ This code is only utilized in the potash tract database.

${ }^{2}$ This designation is only used in the potash deposits and occurrences database.
}

\footnotetext{
${ }^{2} \mathrm{http}: / /$ geonames.usgs.gov/

${ }^{3}$ http://earth-info.nga.mil/gns/html/
} 
soluble, few potash deposits or occurrences are exposed at the surface. Approximate locations from page-size maps, nearby towns, or other geographical features were used to select areas that were later examined using satellite imagery in Google Earth.

In a few instances, a grouped record was created if several smaller mines or occurrences in the same vicinity (less than $4 \mathrm{~km}$ apart) were merged, if reserves or resources were reported as an aggregate, or if the literature referred only to an aggregated entity. In most cases, component occurrences were retained in the database to preserve the original diversity of the information; this means that the database contains some level of duplication, and this is by design.

Overall, most deposits and occurrences are believed to have locations suitable for use at a scale of 1:1,000,000, even though accessing the data through ArcMap allows users to zoom to a much larger scale. Every effort was made to locate each site as accurately as possible, but many locations are based on descriptions in source literature and (or) sketch maps of unknown accuracy and did not have characteristics identifiable on Google Earth or larger-scale geologic maps. Regardless, this compilation provides a better spatial representation of the world distribution of potash deposits and occurrences than previously available.

\section{Geology and Geography of the Potash Deposits and Occurrences Database}

The potash deposits and occurrences database contains 981 records. Sites in this database that list stratabound potashbearing salt (fig. 2-1) and halokinetic potash-bearing salt (fig. 2-2) as the deposit type are about equally divided, with close to 400 sites each listing those types. More than 70 sites list the deposit type as potash-bearing brine deposits (fig. 2-3). Most brine deposits are young, near-surface deposits that originated in continental closed basins. Many of these brines are also enriched in lithium, boron, and (or) magnesium, as well as other elements. Fewer than ten brine deposits are older, intraformational brines such as those in Midland, Michigan.

Sylvite and carnallite (table 2-2) are the most commonly reported potash minerals. Polyhalite, the most common potassium sulfate, is also widely reported and may be under-reported. Polyhalite has been the focus of several recent exploration efforts because of concerns about soil salinization from sylvite and carnallite fertilizers and soil amendments. In the past, polyhalite was assumed to be uneconomic due to its relatively low $\mathrm{K}_{2} \mathrm{O}$ content, despite some minor production in conjunction with other potash halides. Other potash minerals are exploited locally based on site-specific geologic and economic factors.

Most potash deposits and occurrences are classified in the database as occurring in intracratonic basins, with 379 sites listing intracratonic as their basin type (fig. 2-4). Of the remaining sites, 141 are classed as polyphasic basins, 130 are reported to have been deposited in foreland basins and 93 in marine rift basins, and 102 are classed as continental rift basins. Seventy-three sites are in continental closed basins and fewer than two dozen sites each are in other basin types. It is important to note that the dataset for brine and salt deposits in closed continental basins is likely the most incomplete.

The age distribution of potash deposits and occurrences in the database is shown in figure 2-5. The high number of Permian-age deposits and occurrences is a function of several factors: (1) exceptionally detailed occurrence data for the Zechstein and Pricaspian basins relative to that for most other basins, (2) the large size of Permian basins and their contained salt and potash mineralization, and (3) a widespread, high rate of salt deposition during the Permian. In some cases, similar age deposits in basins more than 1,000 km apart, such as the Permian (Kungurian) potash deposits in Eastern Europe and Central Asia, formed in the same or related paleogeographic environments, and potash formed from the same evaporite event (fig. 2-6). Similar relationships likely exist between other potash deposits of the same or similar ages, but are not investigated as part of this report.

Potash deposits are not rare, although most identified by this study are smaller or lower grade than the Saskatchewan deposits that have provided 20 percent or more of the world's potash supply for almost 40 years (Garrett, 1996; Harben, 2002; Jasinski, 2012). The distribution of potash occurrences is quite wide, despite geographically limited historical production centers. Areas notable for a lack of reported potash salt deposits and occurrences include most of eastern, central, and southern Africa, parts of northern North America, Australia, and Russia, and most of China and India. The lack of significant known potash mineralization in most of these areas can be ascribed to one of four factors: (1) age of basinal rocks - potash is less likely to be preserved in Precambrian and early Phanerozoic basinal sequences; (2) degree of metamorphism — potash salts are not likely to be preserved during metamorphism; (3) wet climate - may inhibit conditions permissive for initial deposition of potash or destroy near-surface deposits; or (4) lack of potash or petroleum exploration (many, if not most, known deposits and occurrences were discovered during petroleum exploration). 


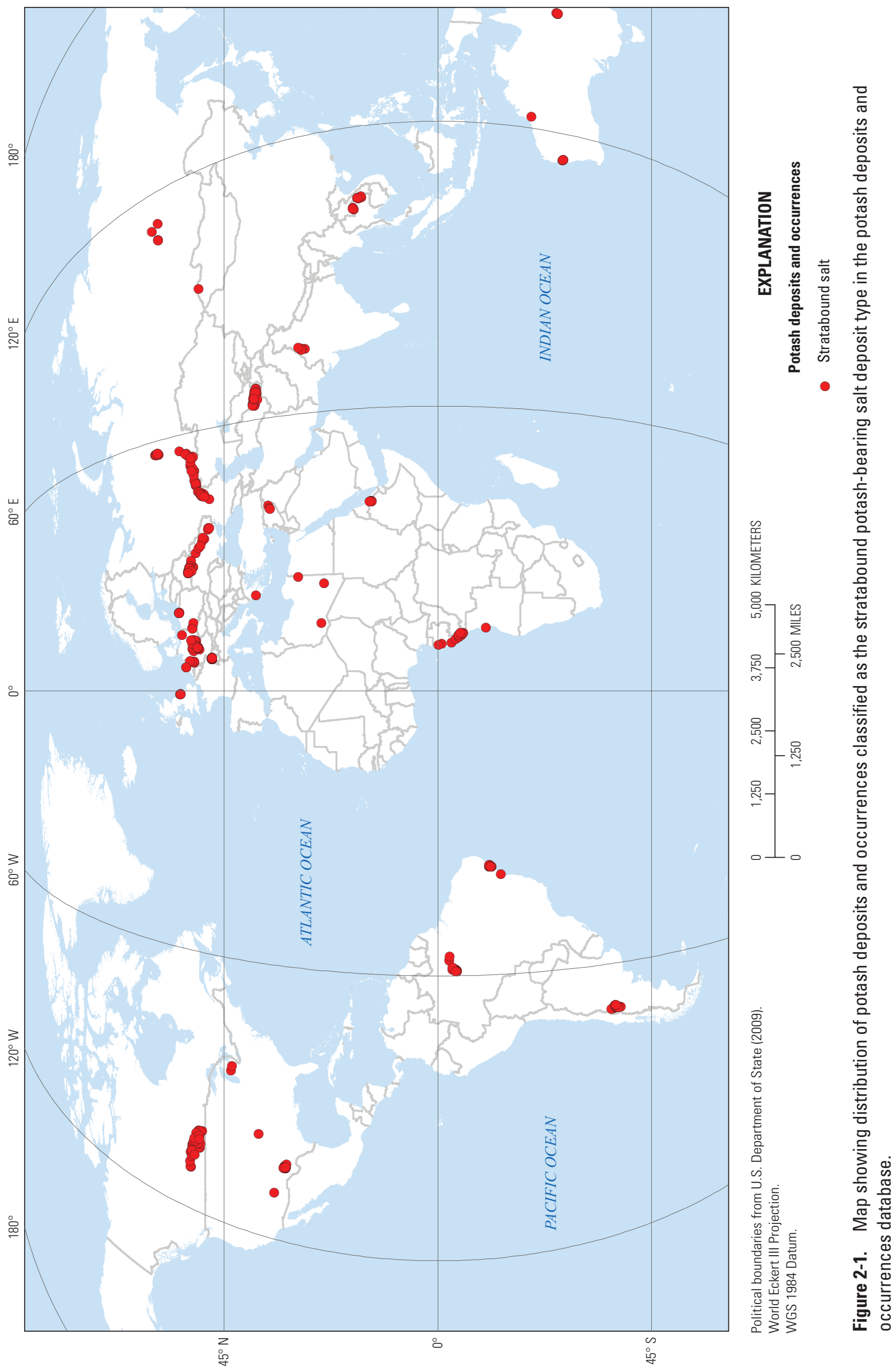



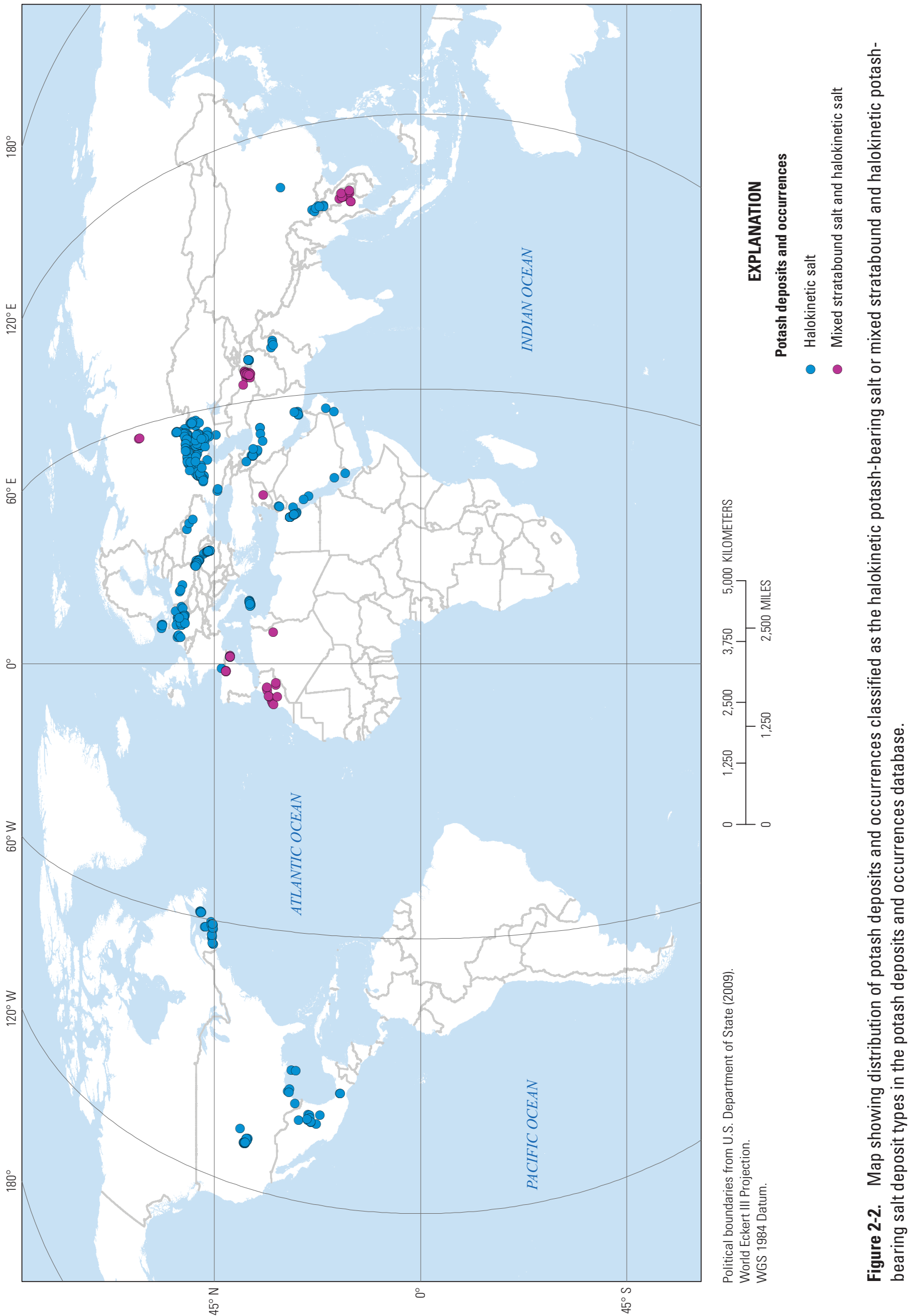


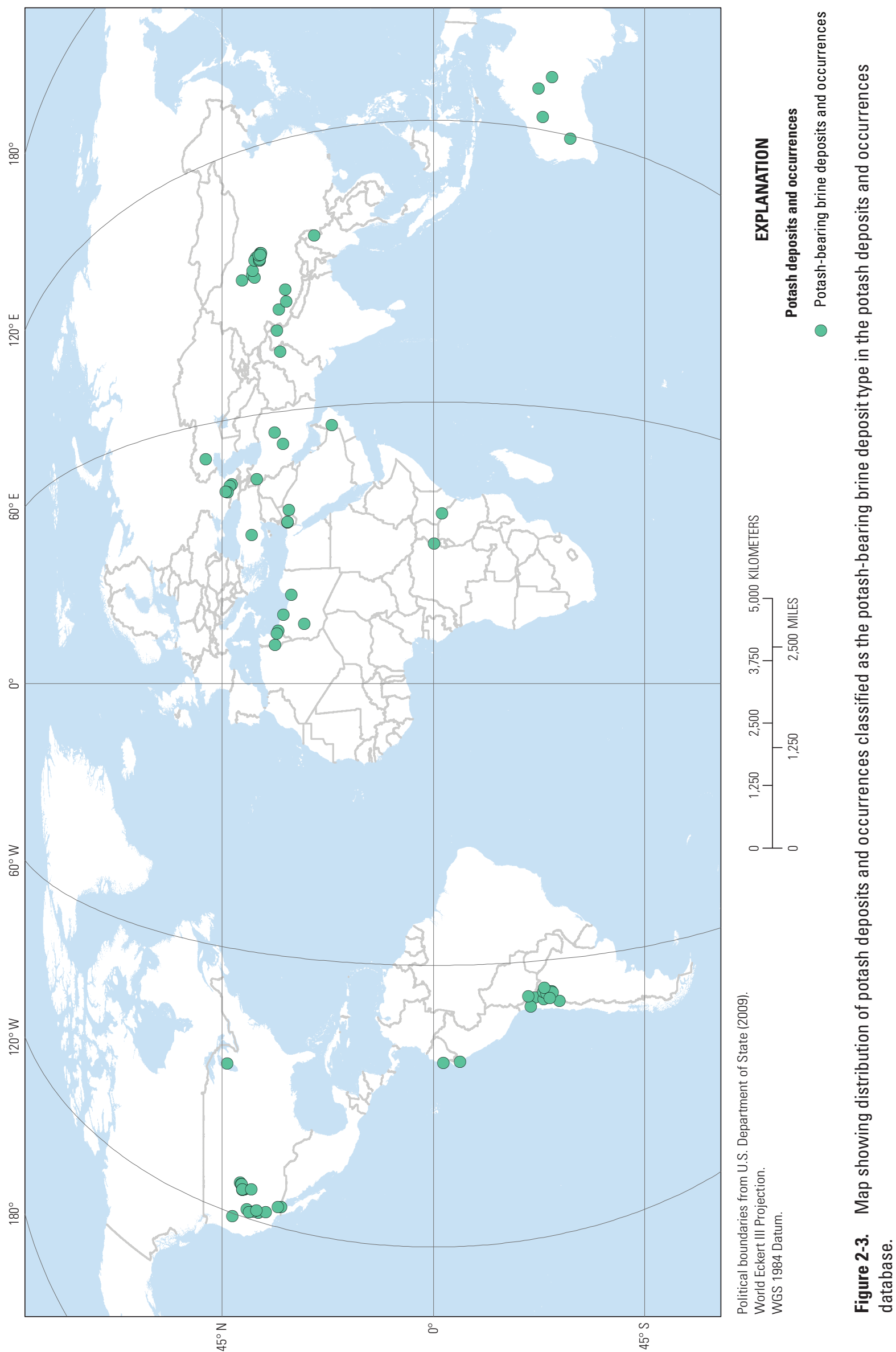


Table 2-2. Potash ore minerals and ore materials.

[Composition formulas from Back and Mandarino (2008); potassium content and specific gravity from Harben and Kuzvart (1996) and Anthony and others $(1997,2003) ;>$, greater than; <, less than]

\begin{tabular}{|c|c|c|c|}
\hline Mineral or material & Composition & $\begin{array}{c}\text { Potassium } \\
\text { oxide }\left(\mathrm{K}_{2} \mathrm{O}\right) \\
\text { (percent) }\end{array}$ & $\begin{array}{l}\text { Specific } \\
\text { gravity }\end{array}$ \\
\hline \multicolumn{4}{|c|}{ Primary potash minerals } \\
\hline Carnallite & $\mathrm{KMgCl}_{3} \cdot 6 \mathrm{H}_{2} \mathrm{O}$ & 16.9 & 1.60 \\
\hline Kainite & $\mathrm{MgSO}_{4} \cdot \mathrm{KCl} \cdot 3 \mathrm{H}_{2} \mathrm{O}$ & 19.3 & 2.10 \\
\hline Langbeinite & $\mathrm{K}_{2} \mathrm{Mg}_{2}\left(\mathrm{SO}_{4}\right)_{3}$ & 22.7 & 2.83 \\
\hline Polyhalite & $\mathrm{K}_{2} \mathrm{Ca}_{2} \mathrm{Mg}\left(\mathrm{SO}_{4}\right)_{4} \cdot 2 \mathrm{H}_{2} \mathrm{O}$ & 15.6 & 2.77 \\
\hline Sylvite & $\mathrm{KCl}$ & 63.2 & 2.00 \\
\hline \multicolumn{4}{|c|}{ Primary potash ore materials } \\
\hline Brine & K-enriched natural saline brine & $>0.5$ & Variable \\
\hline Carnallitite & Mix of halite and carnallite & Up to 15 & Variable \\
\hline Hartsalz & $\begin{array}{l}\text { Mix of sylvite, halite, } \\
\text { anhydrite, and kieserite }\end{array}$ & Typically $<15$ & Variable \\
\hline Sylvinite & Mix of sylvite and halite & Typically $<25$ & Variable \\
\hline \multicolumn{4}{|c|}{ Accessory potassium minerals } \\
\hline Aphthitalite (glaserite) & $(\mathrm{K}, \mathrm{Na})_{3} \mathrm{Na}\left(\mathrm{SO}_{4}\right)_{2}$ & 42.5 & 2.69 \\
\hline Arcanite & $\mathrm{K}_{2} \mathrm{SO}_{4}$ & 54.1 & 2.66 \\
\hline Douglasite & $\mathrm{K}_{2} \mathrm{Fe}^{2+} \mathrm{Cl}_{4} \cdot 2 \mathrm{H}_{2} \mathrm{O}$ & 30.2 & 2.16 \\
\hline Leonite & $\mathrm{K}_{2} \mathrm{Mg}\left(\mathrm{SO}_{4}\right)_{2} \bullet 4 \mathrm{H}_{2} \mathrm{O}$ & 25.7 & 2.20 \\
\hline Niter (saltpeter) & $\mathrm{KNO}_{3}$ & 44.0 & 2.10 \\
\hline Picromerite (schönite) & $\mathrm{K}_{2} \mathrm{Mg}\left(\mathrm{SO}_{4}\right)_{2} \cdot 6 \mathrm{H}_{2} \mathrm{O}$ & 23.4 & 2.03 \\
\hline Rinneite & $\mathrm{K}_{3} \mathrm{NaFe}^{2+} \mathrm{C}_{6}$ & 34.5 & 2.35 \\
\hline Syngenite & $\mathrm{K}_{2} \mathrm{Ca}\left(\mathrm{SO}^{4}\right)_{2} \cdot \mathrm{H}_{2} \mathrm{O}$ & 28.7 & 2.58 \\
\hline \multicolumn{4}{|c|}{ Accessory non-potassium minerals } \\
\hline Anhydrite & $\mathrm{CaSO}_{4}$ & 0 & 2.98 \\
\hline Bischofite & $\mathrm{MgCl} \cdot 6 \mathrm{H}_{2} \mathrm{O}$ & 0 & 1.59 \\
\hline Blödite & $\mathrm{Na}_{2} \mathrm{Mg}\left(\mathrm{SO}_{4}\right)_{2} \cdot 4 \mathrm{H}_{2} \mathrm{O}$ & 0 & 2.23 \\
\hline Dolomite & $\mathrm{CaMg}\left(\mathrm{CO}_{3}\right)_{2}$ & 0 & 2.86 \\
\hline Epsomite & $\mathrm{MgSO}_{4} \cdot 7 \mathrm{H}_{2} \mathrm{O}$ & 0 & 1.68 \\
\hline Gypsum & $\mathrm{CaSO}_{4} \cdot 2 \mathrm{H}_{2} \mathrm{O}$ & 0 & 2.30 \\
\hline Halite & $\mathrm{NaCl}$ & 0 & 2.17 \\
\hline Hexahydrite & $\mathrm{MgSO}_{4} \cdot 6 \mathrm{H}_{2} \mathrm{O}$ & 0 & 1.76 \\
\hline Kieserite & $\mathrm{MgSO}_{4} \cdot \mathrm{H}_{2} \mathrm{O}$ & 0 & 2.57 \\
\hline Löweite & $\mathrm{Na}_{12} \mathrm{Mg}_{7}\left(\mathrm{SO}_{4}\right)_{13} \cdot 15 \mathrm{H}_{2} \mathrm{O}$ & 0 & $2.36-2.42$ \\
\hline Tachyhydrite & $\mathrm{CaMgCl}_{6} \cdot 12 \mathrm{H}_{2} \mathrm{O}$ & 0 & 1.67 \\
\hline Vanthoffite & $\mathrm{Na}_{6} \mathrm{Mg}\left(\mathrm{SO}_{4}\right)_{4}$ & 0 & 2.69 \\
\hline
\end{tabular}




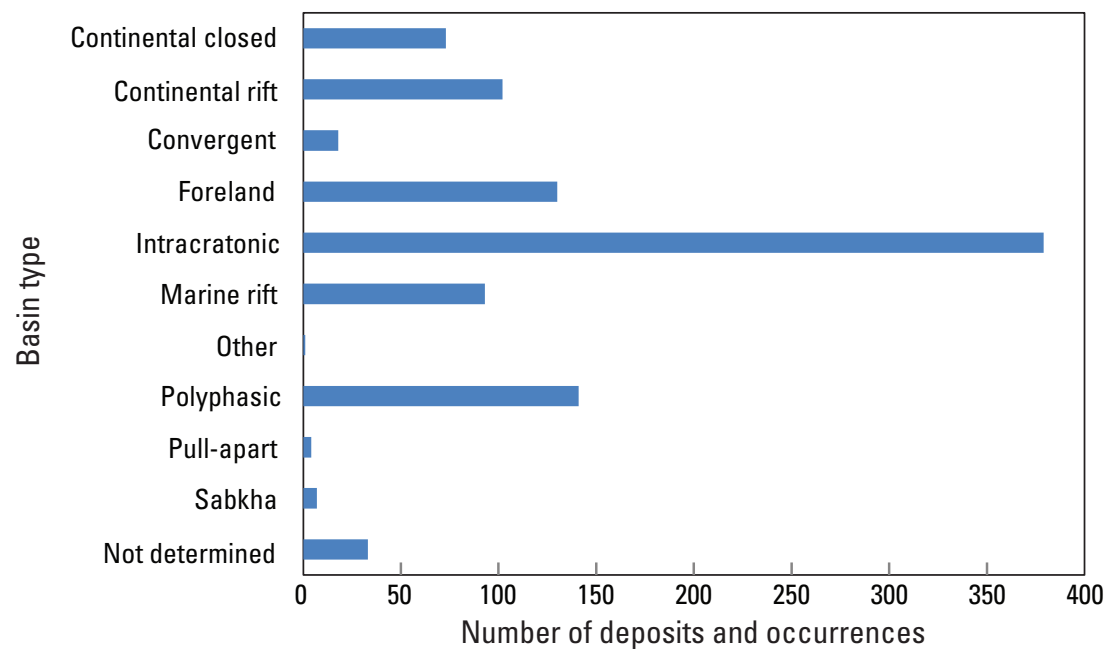

Figure 2-4. Graph showing distribution of basin types within the potash deposits and occurrences database.

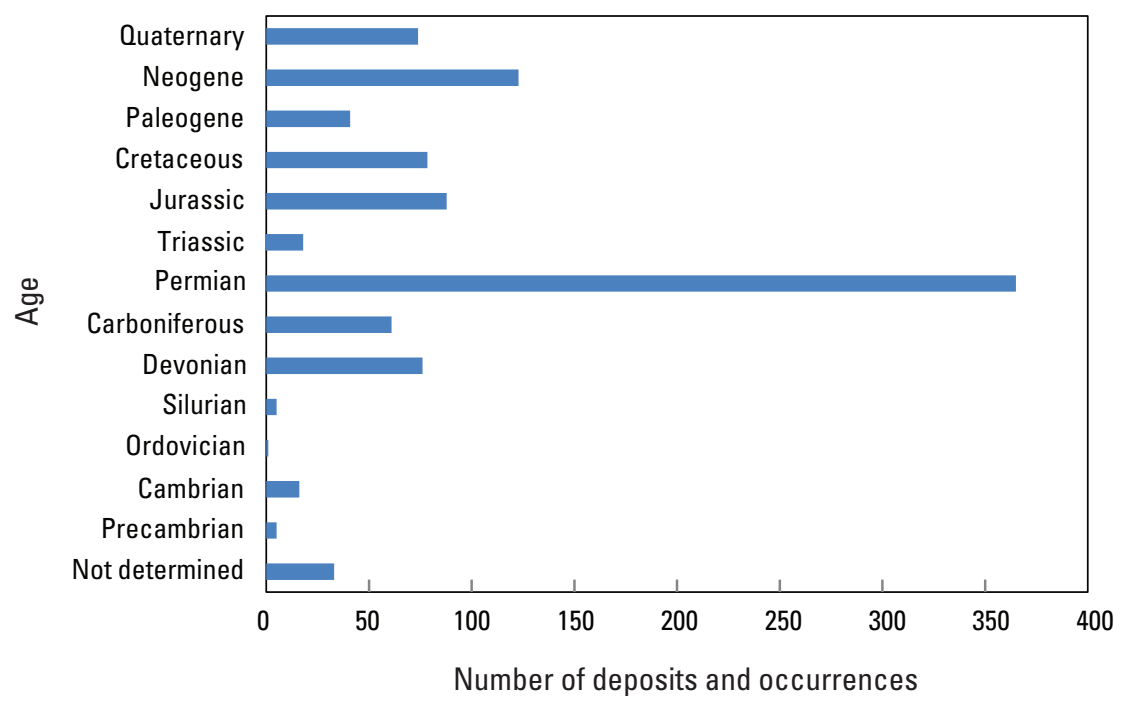

Figure 2-5. Graph showing age distribution, by period, within the potash deposits and occurrences database. Youngest age in range was used for this classification. Mississippian, Pennsylvanian, and Carboniferous are all included under Carboniferous. 


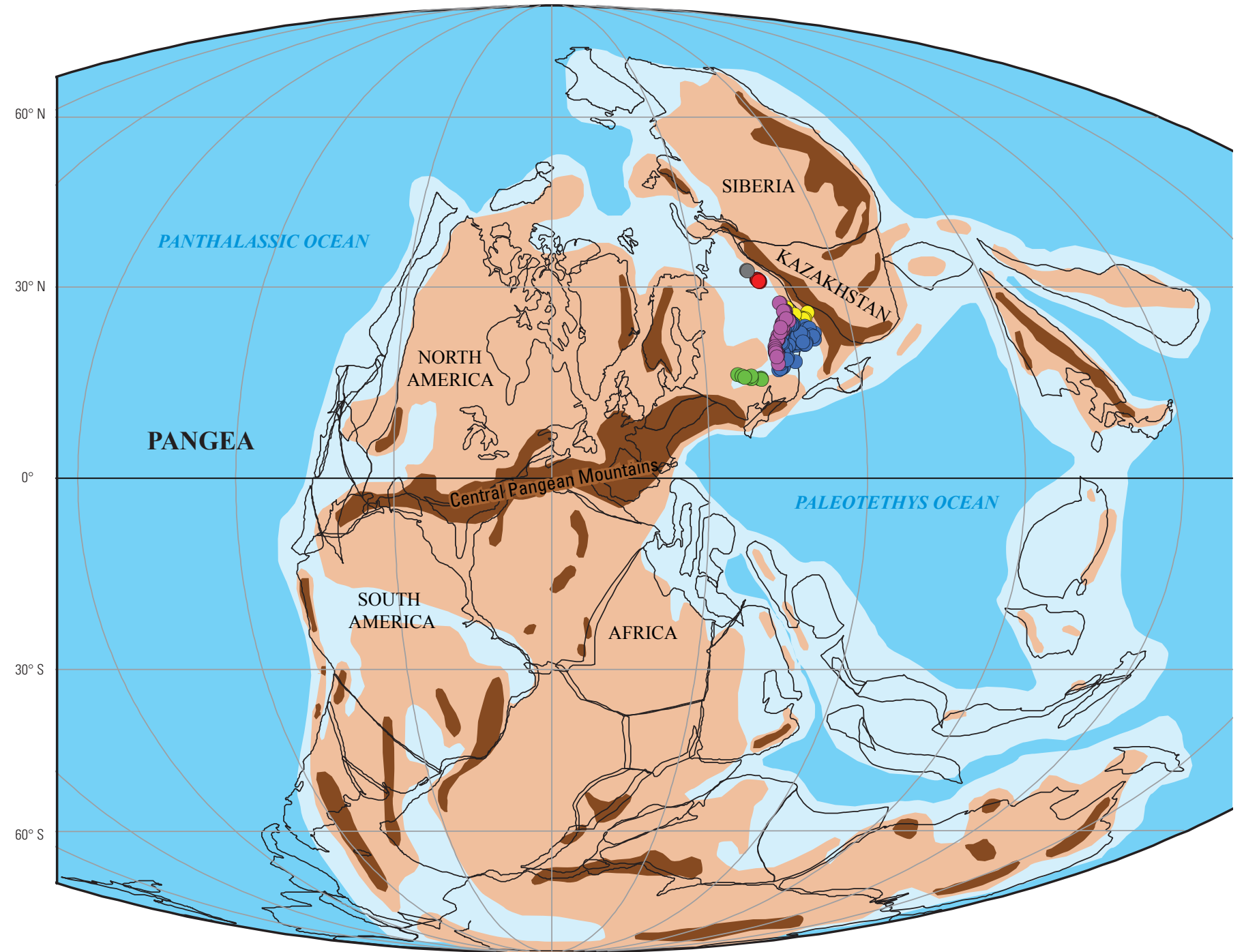

EXPLANATION

280 Мa

Land mass

Mountains

Shallow sea

Ocean

Potash tract occurrences

Volga monocline

- Pricaspian

Cisuralian South

Solikamsk

Dnieper-Donets

Upper Pechora

Figure 2-6. Map showing paleogeographic distribution of Cisuralian-age potash deposits of Eastern Europe and their relation to the Paleotethys Ocean and Pangea. Deposits are color-coded by host assessment tract (see chapter 3). Paleogeographic base from Scotese (2008). 


\section{Potash Deposits and Occurrences Database Fields}

The potash deposits and occurrences database is available in multiple formats as described in chapter 4. Data fields and their descriptive information are the same in all formats, with two exceptions, Field Descriptor ${ }^{4}$ and Short Definition, which are named Alias and Definition, respectively, in the Esri geodatabase (table 2-3). In addition to descriptive information, graphics are available for some sites in the database. These graphics are accessible from within the GIS data, and are also available as portable document files (PDFs) included with the digital files accompanying this report (see chapter 4).

Data field names in the potash deposits and occurrences database are described below in the following format:

Field Descriptor (FIELD_NAME): Short Definition. Additional explanatory information.

Fields in the potash deposits and occurrences database include:

Identification Number (ID_NO): Unique numeric identifier for each site.

Site Name (SITE_NAME): Name of the site. Sites include mines, deposits, occurrences, structures, mineralized areas, and basins. The type of feature represented by each site record is listed in Type of Record, described below.

As with most mineral-related features, site names can be a source of confusion. A feature can take its name from nearby topographic or geologic features, cities, mines, leases, or company projects; it is common to have more than one name for the same site. Variant spellings derive from different systems used to transliterate from other scripts into the Latin alphabet. With large deposits or mineralized areas, the same name might be used to refer to a single mine or occurrence, many sites within the area, or to the area as a whole. A name may also change over time as the result of a change in ownership. For some deposits, new shafts or other workings may introduce new names that apply to the same mine or deposit. The authors of this compilation have addressed these issues

\footnotetext{
${ }^{4}$ In this report, field descriptors are shown in Times New Roman bold (for example, Site Name), field names in Arial bold (for example, SITE_NAME), and field data values in bold italics (for example, area).
}

Table 2-3. Relation between data field terms used in chapters 2 and 3 of this report and Esri geodatabase terminology.

\begin{tabular}{lll}
\hline \multicolumn{1}{c}{ This report } & \multicolumn{1}{c}{ Esri } & \multicolumn{1}{c}{ Explanation } \\
\hline Field Descriptor & Alias & $\begin{array}{l}\text { Short field descriptor of field, easily } \\
\text { understood by a geologist or a person } \\
\text { with limited GIS knowledge }\end{array}$ \\
Field Name & Field Name & $\begin{array}{l}\text { ESRI field name, restricted to } \\
10 \text { characters }\end{array}$ \\
Short Definition & Definition & Explanation of the field contents \\
\hline
\end{tabular}

to the extent possible; however, naming problems and inconsistencies, as well as duplicated records, may still exist in the database.

\begin{abstract}
Alternate Names (ALT_NAMES): Other name(s) for site. Some names in this field may represent larger or smaller areas than the site record represents, but are included because information related to the site record may be found under these names and this information is included in the database record.
\end{abstract}

Type of Record (TYPE_REC): Site type; queried where uncertain; multiple descriptive terms may be present. This field contains a descriptive term(s) for the type of record represented by Site Name. These terms include area, basin, brine, deposit, drill hole, grouped mines/ occurrences, lease/concession/permit area, mine, mine(?), mineral occurrence, and structure. The term structure is used for a salt structure where potash has been reported. For the purposes of this field, the term deposit is restricted to entities with known reserves and (or) resources, including production if the site has produced potash. The term area represents a notable, but variable, extent of mineralization and also includes deposits for which size and grade have not been defined. A record type of grouped mines/occurrence is listed if several smaller mines or occurrences occur within $4 \mathrm{~km}$ of each other, smaller mines historically merged into larger mines, reserves and (or) resources are reported at the aggregated level, or if the literature refers to the aggregated entity. Multiple descriptive terms exist for some records and are separated by commas. Data are queried where uncertain.

Country (COUNTRY): Country (or group of countries) in which the potash site is located. 
Latitude (LATITUDE): Latitude in decimal degrees. Positive number represents latitude north of the equator; negative number represents latitude south of the equator.

Longitude (LONGITUDE): Longitude in decimal degrees. Positive number indicates a longitude east of the Greenwich meridian; negative number represents longitude west of the Greenwich meridian.

Basin (BASIN): Evaporite basin containing potash mineralization. The basin name most appropriate for the potash and evaporite mineralization was used. This was determined from the literature available for each site or for the tract in which the site occurs (see chapter 3). A basin may be distinctly different in terms of shape or size at different points in its history. Some geologic units may be present in parts of a basin and not in others. In cases where several names are associated with a single basin, we selected the name associated with the age and extent most closely related to the potash mineralization. If no detailed information was available, the basin name was assigned based on the best-fit petroleum basin name from published U.S. Geological Survey or American Association of Petroleum Geologists compilations or the name of the lake or playa occupying a closed continental basin.

Basin Type (BASIN_TYPE): Type of sedimentary basin; queried where uncertain. The basin type listed is that which most appropriately describes the basin at the time of evaporite deposition. Basin types for this database are listed in table 2-4. No specific classification system was used; instead, every effort was made to select the basin type most appropriate to the potash mineralization. Some basins have undergone complex histories during which more than one basin type could be applied to, or played a role in, the potash mineralization; in this case the term polyphasic was used. The basin type for each site was determined from the literature or by the tract in which the site occurs (see chapter 3 ). If the basin type cannot be determined or is unknown, then not determined is listed in this field. If the basin type is known, but not defined in table 2-4, then other is listed in this field.

Tract Name (TRACT_NAME): Informal name of the permissive potash tract in which the potash site occurs. Not all sites occur within delineated permissive tracts. These tracts are described in chapter 3 of this report and are a component of the GIS, Excel, and KML files included in this report.
Deposit Type (DEP_TYPE): Potash deposit type(s) most likely to be present; queried where uncertain. Entries in this field are listed in table 2-1, along with the pertinent deposit type model or an explanation. For deposits found within tract boundaries (chapter 3), the deposit type listed is compatible with that listed for the host tract where specific site information is available or is the same as that listed for the host tract where no specific site information was available. For instance, if the host tract deposit type is listed as mixed stratabound and halokinetic potash-bearing salt, then the potash occurrence deposit type will be listed as stratabound potash-bearing salt, halokinetic potash-bearing salt, or as potash-bearing brine. Sites occurring outside tract boundaries, where available information does not allow a specific deposit type classification, are assigned a generic evaporite classification.

Commodities (COMMODS): Significant commodities present; queried if presence is uncertain; multiple commodities are listed in approximate order of significance (and are delimited by two spaces). Abbreviations used in this field are defined in table 2-5. Halite, although not always listed, is typically present in potash-bearing evaporite deposits, including sulfatedominated deposits.

Potash Minerals (K_MINERALS): Potash minerals and materials known to be present; queried where uncertain; listed in approximate order of abundance or importance. A list of potash minerals and materials with compositional information and $\mathrm{K}_{2} \mathrm{O}$ contents can be found in table 2-2. Field contains no entry where potassium-bearing minerals are not identified and (or) known.

Other Minerals (OTHER_MINS): Other mineral(s) of significance or interest; queried where uncertain; listed in approximate order of abundance or importance. These may include potential by- or co-product minerals or gangue and trace minerals that are useful for determining deposit type or for other geologic interpretation. Halite and gypsum are not always listed where present. Field contains no entry where minerals in this category are not known or not reported.

Geologic Era (AGE_ERA): Geologic era(s) of potash mineralization; multiple terms are delimited by hyphens. Eras are defined based on the International Stratigraphic Chart (International Commission on Stratigraphy, 2010). Where the age of the potash mineralization is not known, not known is entered in this field. 
Table 2-4. Tectonic settings and basin types used in this study.

[Not all basin types in basin classification schemes are included, as they may not be conducive to potash mineralization or preservation. Many basins are complex and have more than one type during basin evolution.*, sabkha is only present in potash deposits and occurrences database, which does not contain a tectonic setting field; **, basin type "other" is only present in the potash deposits and occurrences database]

\begin{tabular}{|c|c|c|c|c|}
\hline Tectonic setting & Basin type & Basin type synonym(s) & Definition & Reference(s) \\
\hline Divergent margin & Marine rift basin & $\begin{array}{l}\text { Ocean margin basins; } \\
\text { youthful-Red Sea type; } \\
\text { mature-Atlantic type; } \\
\text { continental margin sag }\end{array}$ & $\begin{array}{l}\text { Long, narrow trough bounded by normal and } \\
\text { listric faults marking zone where lithosphere } \\
\text { has ruptured under extensional tectonics. } \\
\text { Extension results in plate breakup and oceanic } \\
\text { crustal development and seafloor spreading. }\end{array}$ & $\begin{array}{l}\text { Ravnas and } \\
\text { Steel (1998); } \\
\text { Miall (1984); } \\
\text { Kingston and } \\
\text { others (1983) }\end{array}$ \\
\hline Convergent margin & Convergent basin & Collision basin & $\begin{array}{l}\text { A basin formed at a convergent margin. May } \\
\text { involve continental and oceanic plate collisions. }\end{array}$ & $\begin{array}{l}\text { Leeder (1999); } \\
\text { Miall (1984) }\end{array}$ \\
\hline Convergent margin & Foreland basin & & $\begin{array}{l}\text { A linear sedimentary basin in the exterior } \\
\text { area of a contractional orogenic belt where } \\
\text { deformation occurs without significant } \\
\text { metamorphism. Generally formed on continental } \\
\text { crust between orogenic belt and craton. }\end{array}$ & $\begin{array}{l}\text { DeCelles and } \\
\text { Giles (1996); } \\
\text { Miall (1984) }\end{array}$ \\
\hline $\begin{array}{l}\text { Transform or } \\
\text { transcurrent fault } \\
\text { zone or boundary }\end{array}$ & Pull-apart basin & $\begin{array}{l}\text { Strike-slip basin, } \\
\text { wrench basin }\end{array}$ & $\begin{array}{l}\text { A topographic depression centered over an } \\
\text { extensional bend or extensional step-over of a } \\
\text { strike-slip fault. }\end{array}$ & $\begin{array}{l}\text { Mann and } \\
\text { others (1983); } \\
\text { Miall (1984) }\end{array}$ \\
\hline Craton & Intracratonic basin & Cratonic basin & $\begin{array}{l}\text { A basin formed within the interior region of a } \\
\text { continent, as a regional downwarp away from } \\
\text { plate boundaries (such as epicontinental sea). }\end{array}$ & $\begin{array}{l}\text { Middleton (1980); } \\
\text { Miall (1984) }\end{array}$ \\
\hline Craton & $\begin{array}{l}\text { Continental closed } \\
\text { basin }\end{array}$ & $\begin{array}{l}\text { Chott, salar, inland sea, } \\
\text { playa, salt lake }\end{array}$ & $\begin{array}{l}\text { Enclosed area with no drainage; water escapes } \\
\text { only by evaporation. }\end{array}$ & $\begin{array}{l}\text { Neuendorf and } \\
\text { others (2005) }\end{array}$ \\
\hline Marginal marine & Sabkha* & & $\begin{array}{l}\text { A supratidal environment of sedimentation, } \\
\text { formed under arid to semiarid conditions on } \\
\text { restricted coastal plains just above normal } \\
\text { high-tide level (a saline marine marsh) or can } \\
\text { be any coastal or interior flat area where in } \\
\text { the near surface, saline minerals crystallize } \\
\text { through deflation and evaporation processes. }\end{array}$ & $\begin{array}{l}\text { Leeder (1999); } \\
\text { Handford (1991); } \\
\text { Warren (1991) }\end{array}$ \\
\hline \multirow[t]{2}{*}{ Unknown } & Not determined & & $\begin{array}{l}\text { No information was located describing tectonics } \\
\text { or basin at time of salt deposition. }\end{array}$ & \\
\hline & Other** & & $\begin{array}{l}\text { Basin type is known, but not explicitly included } \\
\text { in this list because would only occur once or } \\
\text { twice. }\end{array}$ & \\
\hline
\end{tabular}


Table 2-5. Commodity codes.

\begin{tabular}{ll}
\hline & \multicolumn{1}{c}{ Code } \\
\hline B & Bommodity \\
BR & Bromine \\
BRI & Brine \\
CA & Calcium \\
CL & Chloride \\
GYP & Gypsum \\
H2S & Hydrogen sulfide gas \\
HAL & Halite \\
I & Iodine \\
K & Potash \\
LI & Lithium \\
MG & Magnesium \\
NA & Sodium \\
NACO & Sodium carbonate (trona) \\
NASO & Sodium sulfate \\
NO3 & Nitrate \\
P & Phosphate \\
S & Sulfur \\
SO4 & Sulfate \\
\hline
\end{tabular}

Geologic Period (AGE_PERIOD): Geologic period(s) of potash mineralization; queried where uncertain; multiple terms are hyphen-delimited. If an age range is needed, all periods from oldest to youngest are listed in chronographic order. Periods are defined based on the International Stratigraphic Chart (International Commission on Stratigraphy, 2010). Square brackets enclosing the phrase no defined period are used to anchor an age range where no epoch is defined for one end of the range; for example, [no defined period]-Cambrian is used where no epochs are defined for the Neoproterozoic. Field contains no entry if period is not known.

Geologic Epoch (AGE_EPOCH): Geologic epoch(s) of potash mineralization; queried where uncertain; multiple terms are hyphen-delimited. If an age range is needed, all epochs from oldest to youngest are listed in chronographic order. Epochs are defined on the basis of the International Stratigraphic Chart (International Commission on Stratigraphy, 2010). Square brackets enclosing the phrase no defined epoch are used to anchor an age range where no epoch is defined for one end of the range; for example, [no defined epoch]-Lower Cambrian is used where no epochs are defined for the Neoproterozoic. Field contains no entry if epoch is not known.

Geologic Stage (AGE_STAGE): Geologic stage(s) of the assessed potash-bearing evaporite; queried where uncertain; multiple terms are hyphen-delimited. All stages appropriate to the mineralization age range are listed. If an age range is needed, all stages from oldest to youngest are listed in chronographic order. Square brackets and the word recent are used to anchor an age range where one end of the range does not have a stage name; for example, Upper Pleistocene-[recent]. Stages are defined based on the International Stratigraphic Chart (International Commission on Stratigraphy, 2010). Field contains no entry if stage is not known.

Oldest Age (MAX_AGE): Oldest age of potash mineralization; queried where uncertain; presented as a hyphen-delimited concatenation of geologic era, followed by geologic period, epoch, and stage, where known. No entry indicates age is not known. Terms are defined based on the International Stratigraphic Chart (International Commission on Stratigraphy, 2010).

Youngest Age (MIN_AGE): Youngest age of potash mineralization; queried where uncertain; presented as a hyphen-delimited concatenation of geologic era, followed by geologic period, epoch, and stage, where known. No entry indicates geologic age is not known. Terms are defined based on the International Stratigraphic Chart (International Commission on Stratigraphy, 2010).

Host Rock Units (UNIT): Host rock unit in which potash mineralization occurs; queried where uncertain. Field includes formal or informal names of the host units as reported by the source materials. Abbreviations used in this field can be found in appendix D. No entry indicates that data are not reported or not known.

Host Rock Lithology (LITH): Lithology and (or) composition of the host rock and (or) unconsolidated sediment; multiple terms are comma-delimited. Order indicates relative abundance in the vicinity of the potash mineralization. No entry indicates the host rock lithology is not reported or not known.

Associated Salt Structure (SALT_STR): Name of salt structure associated with the potash site, if any. Field is attributed only for sites with a deposit type of halokinetic potash-bearing salt or mixed stratabound and halokinetic potash-bearing salt. No entry for halokinetic potash occurrence indicates the salt structure is not reported, not named, or not known.

Potash Thickness (K_THK_M): Reported thickness or range in thickness of the potash or potash-bearing sequences(s); values for multiple sequences are delimited by semicolons. Values in this field are given in meters (m). The reported thickness is usually the thickness of a single unit or mineable layer, but may represent the total aggregate thickness of several potash horizons; this was commonly not specified in the source literature. Thickness may be reported as a single value or as a range of values. For some sites, thicknesses of multiple beds or horizons may be specified and are separated by semicolons. Each 
specific bed or horizon name is followed by a colon and then the thickness. No entry indicates that thickness is not reported and (or) not known.

Potash Depth (K_DEPTH_M): Reported depth to the top of the potash mineralization; values may represent a range in depth; values for multiple sequences are delimited by semicolons. Values in this field are given in meters (m). This depth value may indicate depth to the first horizon of any potash mineral or it may indicate depth to the top of the first mineable or sylvite-dominated horizon; again, much of the source literature was not specific on this issue. Depth is reported as a single value or a range of values. For some sites, multiple beds or horizons are present and depths to each are specified and separated by semicolons. Each specific bed or horizon name is followed by a colon and then depth. No entry indicates that depth is not reported and (or) not known.

Geologic Notes (GEOL_NOTES): Additional geologic information, if any, for site.

Average K2O Grade (AV_K2O_PCT): Reported average grade or range in grade, in percent $\mathrm{K}_{2} \mathrm{O}$, not associated with stated production or reserve information. No entry indicates data were not reported and (or) not known.

Figures (FIGURES): Image(s) portraying one or more geologic aspects of the site, in PDF format; includes name of subfolder. These graphics are interactive within the geodatabase and are stored in the folder $\backslash$ Figures as PDF files accessible to those without ArcMap access. The link to a given site may contain a single graphic or multiple graphics. The naming convention for these graphics is explained in chapter 3, table 3-6. No entry in the field indicates no figures for that site are included in the data package.

Production Status (P_STATUS): Production and (or) development status; queried where uncertain; year in parentheses indicates date information was current.

Production Status choices include Active Production, Past Production, Small Production, Small Past Production, None, Under Development, and Not Determined. Under Development was included because the production status of that site is likely to change in the short term. Small Production and Small Past Production are differentiated to accommodate production level differences between modern mines and the much smaller levels of production typically found for historical mines and artisanal operations.

Year First Produced (P_FIRST_YR): Reported year(s) of first potash production, may include a second value for year mining resumed after a long hiatus; queried where uncertain. No entry indicates that year is not reported and (or) not known.
Year Last Produced (P_LAST_YR): Reported year(s) of last potash production, may include a second value for year mining ceased after a second startup; queried where uncertain. No entry indicates that year is not reported and (or) not known.

Company (COMPANY): Name of company(s); year in parentheses indicates the date the information was known to be correct; multiple entries are delimited by semicolons. No entry indicates that data are not reported and (or) not known.

Ore Produced (P_ORE_MT): Reported production of ore (in millions of metric tons, $\mathrm{Mt}$ ); multiple values are delimited by semicolons; entries listed by number correspond to the respectively numbered source listed in Production References. No entry indicates that production data are not reported and (or) not known.

$\mathbf{K}_{2} \mathbf{O}$ Produced (P_K2O_MT): Reported production of contained potash (as $\mathrm{K}_{2} \mathrm{O}$ in millions of metric tons, $\mathrm{Mt}$ ); multiple values are delimited by semicolons; entries listed by number correspond to the respectively numbered source listed in Production References. Contained potash values reported as $\mathrm{KCl}$ or $\mathrm{K}$ were converted to equivalent $\mathrm{K}_{2} \mathrm{O}$ values. No entry indicates that production that data are not reported and (or) not known.

Production Grade (P_K2O_PCT): Grade of reported potash production, as percent $\mathrm{K}_{2} \mathrm{O}$; multiple entries are delimited by semicolons; entries listed by number correspond to the respectively numbered source listed in Production References. No entry indicates that production data are not reported and (or) not known.

Production References (P_REFS): Abbreviated citation(s) for source reference(s) of the production data provided in Ore Produced, $\mathbf{K}_{2} \mathbf{O}$ Produced, and Production Grade; multiple references are delimited by semicolons; references listed by number correspond to the respectively numbered values in Ore Produced, $\mathbf{K}_{2} \mathbf{O}$ Produced, and Production Grade. Full references are listed in the "References Cited" worksheet in the descriptive data file (PotashDeposits.xlsx) that accompanies the spatial database. No entry indicates that production data are not reported and (or) not known.

Production Years (P_YEARS): Year(s) or range of years of production data provided in Ore Produced, $\mathrm{K}_{2} \mathrm{O}$ Produced, and Production Grade; queried where uncertain; multiple values are delimited by semicolons; values listed by number correspond to the respectively numbered values in Ore Produced, $\mathbf{K}_{2} \mathbf{O}$ Produced, and Production Grade. No entry indicates that production data are not reported and (or) not known. 
Measured Inventory (MEAS_INVEN): Categorical field for known reserves or resources. Yes if reserves or resources are reported for the record. Field contains no entry if reserves/resources data are not reported and (or) not known.

Ore Reserves/Resources (RR_ORE_MT): Reported reserves and (or) resources of ore (in millions of metric tons, Mt); multiple entries are delimited by semicolons; entries listed by number correspond to the respectively numbered source listed in Reserves/Resources References. Abbreviations are defined in appendix D. No entry indicates reserves/resources data are not reported and (or) not known.

$\mathbf{K}_{2} \mathbf{O}$ Reserves/Resources (RR_K2O_MT): Reported reserves and (or) resources of contained $\mathrm{K}_{2} \mathrm{O}$ (in millions of metric tons, $\mathrm{Mt}$ ); multiple entries are delimited by semicolons; entries listed by number correspond to the respectively numbered source listed in Reserves/ Resources References. Abbreviations are defined in appendix D. Contained potash values reported as $\mathrm{KCl}$ or $\mathrm{K}$ were converted to equivalent $\mathrm{K}_{2} \mathrm{O}$ values. No entry indicates that reserves/resources data are not reported and (or) not known.

Reserves/Resources Grade (RR_K2O_PCT): Grade of reported reserves and (or) resources in percent $\mathrm{K}_{2} \mathrm{O}$; multiple values are delimited by semicolons; entries listed by number correspond to the respectively numbered source listed in Reserves/Resources References.

Abbreviations are defined in appendix D. Grades reported as $\mathrm{KCl}$ or $\mathrm{K}$ were converted to equivalent $\mathrm{K}_{2} \mathrm{O}$ values. No entry indicates that reserves/resources data are not reported and (or) not known.

Reserves/Resources References (RR_REFS): Abbreviated citation(s) for source reference(s) of reserve and (or) resource data provided in Ore Reserves/ Resources, $\mathbf{K}_{2} \mathrm{O}$ Reserves/Resources, and Reserves/ Resources Grade; multiple references are delimited by semicolons; references listed by number correspond to the respectively numbered values in Ore Reserves/ Resources, $\mathrm{K}_{2} \mathrm{O}$ Reserves/Resources, and Reserves/ Resources Grade. Full references are listed in the "References Cited" worksheet in the descriptive data file (PotashDeposits.xlsx) that accompanies the spatial database. No entry indicates that reserves/resources data are not reported and (or) not known.

Reserves/Resources Years (RR_YEARS): Year(s) of reserve and (or) resource data provided in Ore Reserves/ Resources, $\mathrm{K}_{2} \mathrm{O}$ Reserves/Resources, and Reserves/ Resources Grade; multiple years are delimited by semicolons; years listed by number correspond to the respectively numbered values in Ore Produced, $\mathbf{K}_{2} \mathbf{O}$ Produced, Production Grade, and Reserves/Resources
References. No entry indicates that reserves/resources data are not reported and (or) not known.

\section{Miscellaneous Notes (MISC_NOTES): Additional information, if any, for site. See appendix D for definitions of abbreviations.}

References (SHORT_REFS): Abbreviated citation(s) for source reference(s) used in compiling the data; multiple citations are delimited by semicolons. Full references can be accessed through the GIS (see chapter 4) and are listed in the "References Cited" worksheet in the descriptive data file (PotashDeposits.xlsx) that accompanies the spatial database.

\section{GIS Data}

Digital data for the potash deposits and occurrences are available in the GIS data files that accompany this report. These data include formats that are accessible to users without access to ArcMap software. File names and complete descriptions are in chapter 4 and in appendixes E and F. Full references for the potash deposits and occurrences database are accessible when using the GIS (see chapter 4) and are listed in the "References" column of the "References Cited" worksheet of the PotashDeposits.xlsx descriptive data file included with this publication.

\section{Summary}

The potash deposits and occurrences database provides a core dataset that can be used to support descriptive and genetic deposit model development, test theories of deposit formation, and otherwise develop a better geologic understanding of evaporite-related potash mineralization. It is clear that many of the deposits and occurrences are more complex than expected. For instance, some deposits have a suite of minerals that would not be expected to develop given the seawater composition at the time of formation. Explanations for this, such as Hardie's (1996) theory linking potash evaporites and variations in seawater chemistry over time or postdepositional processes, do not always adequately account for the observed deposit characteristics. The influence of other sources of fluids and solutes, such as continental runoff and volcanic fluids, is not easily predicted or, in some circumstances, fully understood. Postmineralization fluids, heat, and erosion can also play major roles in altering, or destroying, initial mineralization, but can vary from place to place within a basin as well as between basins and, thus, have distinctly different outcomes. In summary, the potash deposits and occurrences database provides a compilation of deposit-scale information that can be used as a tool to expand research on the genesis, variation, and assessment of available potash resources in a global context. 
This page intentionally left blank. 


\title{
Chapter 3. Potash Assessment Tracts
}

\author{
By Greta J. Orris', Mark D. Cocker1, Pamela Dunlap1', Jeff Wynn², Deborah A. Briggs3, and Gregory T. \\ Spanski ${ }^{4}$ with contributions from James D. Bliss ${ }^{1}$, Karen S. Bolm5 , Chao Yang ${ }^{6}$, Leila Gass ${ }^{1}$, Bruce R. Lipin 7 , \\ Steve Ludington ${ }^{8}$, Robert J. Miller ${ }^{8}$, and Miroslaw Slowakiewicz ${ }^{9}$
}

\section{Introduction}

This chapter describes 84 tracts (fig. 3-1; table 3-1) in which the geology, known potash occurrences, and (or) past or current exploration indicate some level of potential for undiscovered evaporite-related potash resources. These tracts were identified as part of a USGS-led global mineral resource assessment (Schulz and Briskey, 2003; Hammarstrom and others, 2010). Tract delineation is key to defining where undiscovered future resources might be found. Tracts are areas considered to be geologically permissive for a specified deposit type as defined by a descriptive deposit model. Tract boundaries separate areas with the appropriate geology to host commodities and deposit type(s) being investigated from areas where known geology indicates there is no, or negligible, potential (Singer, 1993).

This study delineates tracts likely to contain undiscovered evaporite-related potash resources, particularly stratabound potash-bearing salt and halokinetic potash-bearing salt. Areas where potash occurrences are reported, where there is little additional information and the existence of significant potash resources is uncertain or unlikely, are included in the identified tracts unless there is a certainty that these resources do not exist. The assessment process can include estimates of the amount and quality of the undiscovered resource in these areas; in this report, however, undiscovered resources are not quantitatively estimated for delineated tracts. Instead, the potash tracts identified in this study are classified into six categories that rank their relative potential to provide potash

\footnotetext{
${ }^{1}$ U.S. Geological Survey, Tucson, Arizona, United States.

${ }^{2}$ U.S. Geological Survey, Vancouver, Washington, United States.

${ }^{3}$ U.S. Geological Survey, Spokane, Washington, United States.

${ }^{4}$ U.S. Geological Survey, Denver, Colorado, United States.

${ }^{5}$ U.S. Geological Survey, deceased.

${ }^{6}$ Saskatchewan Geological Survey, Regina, Saskatchewan, Canada.

${ }^{7}$ U.S. Geological Survey, Reston, Virginia, United States.

${ }^{8}$ U.S. Geological Survey, Menlo Park, California, United States.

${ }^{9}$ Polish Geological Institute, Warsaw, Poland.
}

resources in a short to moderate timeframe (25-50 years) based on known resources, geologic setting, level of available information, and availability of infrastructure to support development or mining.

Tracts delineated for potash resources are limited to those containing stratabound and halokinetic potash-bearing salt deposits, a mix of the two deposits, closed basin potashbearing brines, and one well-defined area east of the Aral Sea where several sylvite-bearing occurrences are reported, but neither deposit type nor age is known (see tract 61, fig. 3-1). Tract delineation relies on geologic information and deposit and exploration data to identify sedimentary basins containing salt and (or) salt structures with known or potential potash mineralization. Where sufficient data are available, the extent of any known potash mineralization is used to define boundaries for areas within which undiscovered, potentially economic potash resources might occur. Data characterizing the tracts are presented in the accompanying GIS dataset (see chapter 4). These data include pertinent geology, references, a short summary of the delineation process, and ranking of the tracts. The ranking criteria are described in the Resource Rank field description later in this chapter.

\section{Methodology for Tract Delineation}

The goal of this study is to identify areas where undiscovered potash resources are known or may be present. This is done by delineating tracts based on specified deposit models in a manner compatible with the USGS three-part quantitative assessment methodology described by Singer (1993) and Singer and Menzie (2010). Mineral deposits of a given type share physical and genetic characteristics that differentiate them from other deposit types; deposit models describe geologic characteristics shared by a family of deposits that comprise a deposit model, and the features of a deposit model are used to delineate areas where undiscovered deposits may occur. Delineation of tracts requires the integration of regional and local geology information with knowledge of the deposit type. When tracts are delineated in this manner, and if the input data are valid, the chance for undiscovered potash resources of the selected deposit type existing outside of the tract boundaries is negligible to zero. 


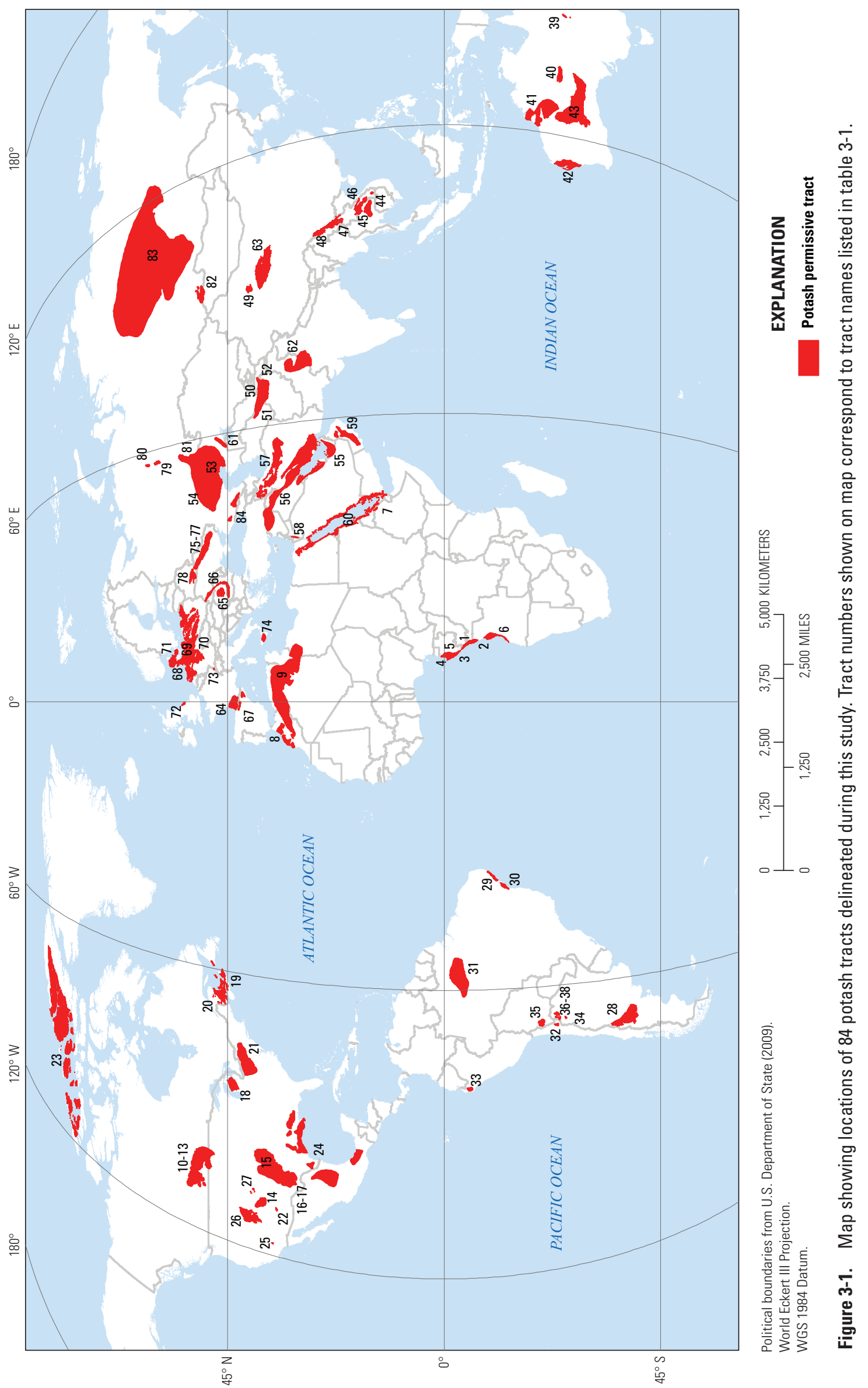


Table 3-1. Index of tract names by number shown in figure 3-1.

\begin{tabular}{|c|c|c|c|}
\hline No. & Tract & No. & Tract \\
\hline 1 & Lower Congo North & 43 & Officer \\
\hline 2 & Lower Congo South & 44 & Khorat \\
\hline 3 & Gabon South halokinetic & 45 & Sakon Nakhon \\
\hline 4 & Gabon North halokinetic & 46 & Lao \\
\hline 5 & Gabon stratabound & 47 & Simao \\
\hline 6 & Kwanza & 48 & Lanping \\
\hline 7 & Danikil & 49 & Tarim \\
\hline 8 & Moroccan Meseta & 50 & Gissar \\
\hline 9 & Saharan & 51 & Amu Darya \\
\hline 10 & Patience Lake & 52 & Afghan-Tajik \\
\hline 11 & Belle Plaine & 53 & Pricaspian \\
\hline 12 & White Bear & 54 & Volga Monocline \\
\hline 13 & Esterhazy & 55 & Hormuz \\
\hline 14 & Paradox & 56 & Zagros \\
\hline 15 & Permian & 57 & Qom-Great Kavir \\
\hline 16 & Permian Salado & 58 & Dead Sea \\
\hline 17 & Permian Rustler & 59 & Oman \\
\hline 18 & Michigan & 60 & Red Sea \\
\hline 19 & Maritimes halokinetic & 61 & Priaralian \\
\hline 20 & Maritimes stratabound & 62 & Nagaur \\
\hline 21 & Salina & 63 & Qaidam \\
\hline 22 & Holbrook & 64 & Aquitaine \\
\hline 23 & Sverdrup & 65 & Transylvanian \\
\hline 24 & Gulf of Mexico & 66 & Carpathian \\
\hline 25 & Searles & 67 & South Pyrenean \\
\hline 26 & Bonneville & 68 & Zechstein Glückstadt \\
\hline 27 & Eagle & 69 & Zechstein halokinetic \\
\hline 28 & Neuquén & 70 & Zechstein stratabound \\
\hline 29 & Sergipe & 71 & Zechstein Denmark \\
\hline 30 & Reconcavo & 72 & Zechstein United Kingdom \\
\hline 31 & Amazonas & 73 & Rhine Graben \\
\hline 32 & Atacama & 74 & Sicily \\
\hline 33 & Sechura & 75 & Dnieper-Donets Permian \\
\hline 34 & Hombre Muerto-Diablillos & 76 & Dnieper-Donets Devonian halokinetic \\
\hline 35 & Uyuni & 77 & Dnieper-Donets Devonian stratabound \\
\hline 36 & Olaroz-Cauchari & 78 & Pripyat \\
\hline 37 & Rincón & 79 & Solikamsk \\
\hline 38 & Salinas Grandes & 80 & Upper Pechora \\
\hline 39 & Adavale & 81 & Cisuralian South \\
\hline 40 & Amadeus & 82 & Uvs Nuur \\
\hline 41 & Canning & 83 & East Siberian \\
\hline 42 & Carnarvon & 84 & Ciscaucasian \\
\hline
\end{tabular}

In geologically well described locations, this process is relatively straightforward and tract boundaries correspond to mapped surficial or subsurface geologic features. In less well described locations, tract boundaries are based on interpretation of ancillary information, such as drill hole data or geophysics, and may not follow mapped geologic contacts or features.

A descriptive deposit model describes key geologic features of a specified deposit type. This description typically includes tectonic and depositional setting, host rock, structure, mineralization, and other geologic characteristics that help distinguish this type of deposit from similar deposits. Descriptive models provide a checklist of both required and common features that should or may be present in areas where undiscovered deposits of the selected deposit type might occur. This study of potash focuses primarily on evaporitehosted potash deposits, specifically, stratabound potashbearing salt and halokinetic potash-bearing salt deposits. 
Summaries of models for these types of deposits can be found in appendixes A and B, respectively. In addition, tracts are delineated for potash-bearing brine deposits in closed continental basins as there is current production from these types of deposits in the United States (Bonneville tract [26], fig. 3-1), Chile (Atacama tract [32]), and China (Tarim [49] and Qaidam [63] tracts). A short description of this deposit type can be found in Orris (2011). Tracts for intra-formational potash-bearing brines are not delineated.

For this study, tracts are restricted to onshore areas where the resource is at a depth of less than $3 \mathrm{~km}$. For a few tracts, much of the potash is known to occur at depths greater than $2.5 \mathrm{~km}$ (such as in the Ciscaucasian tract), and due to widely spaced and incomplete data at depth, we may not recognize local areas within the tract where potash surpasses a depth of $3 \mathrm{~km}$. Areas where potash minerals are known or may occur are commonly identified using the potash deposits and occurrences database, geologic maps, cross sections, drill hole data and (or) other geologic information. For areas where the extent or probable extent and depth of potash mineralization cannot be defined, tracts are delineated on the basis of the presence of salt or salt structures. This information is largely sourced from available geologic maps and sketches. In many of these areas, however, drill hole data are spotty or data logs are incomplete. Mapped extents of structures are used to define potash deposits where salt structures are mapped across an entire area, are expected to have potential for potash, and are wholly or partly above the $3-\mathrm{km}$ depth limit. Mapped extents of structures are used to define potash deposits. This methodology is used for halokinetic potash tracts in the Dnieper-Donets (tract 76, fig. 3-1) and Zechstein (tract 69, fig. 3-1) basins and in other areas affected by salt flow and tectonics. Unmapped or incompletely identified salt structures are assumed to be contained in the delineated area; for instance, the Afghan-Tajik halokinetic tract (tract 52, fig. 3-1).

In some areas where relatively little geologic mapping or exploration has occurred, or where data have not been published for other reasons, the areal extent of salt or potashbearing strata has not been determined. When the geologic units and (or) age of units hosting potash mineralization are known, geologic maps are used to identify mapped units of the appropriate age and (or) lithology, as well as younger units that might conceal potential host rocks within an evaporite basin. The extent of an evaporite basin, in the absence of a known mapped boundary, is determined by the maximum extent of evaporites, such as halite and gypsum, within strata of the potash mineralization age or age-range. Point data, such as potash occurrences in drill holes, salt structures, and other geologic records, are commonly used to further refine tract boundaries.

The potash tracts database contains specific information on how each tract has been delineated in the Delineated Feature Type, Geologic Summary, and Tract Delineation fields. These fields are described in the "Potash Tracts Database Fields" section of this chapter. Detailed processing steps in digitizing the tracts are documented in the metadata accompanying the GIS data, which is described in chapter 4 .

\section{Geology, Geography, and Mineral Economics of Potash Tracts}

Eighty-four potash tracts, distributed across six continents (exclusive of Antarctica), are described in this publication and most of these tracts delineate areas permissive for occurrence of the two deposit types of primary interest: stratabound potash-bearing salt and halokinetic potash-bearing salt. For the purposes of this study, and as defined in appendix A, stratabound potash-bearing salt deposits are relatively flatlying salt deposits with interbedded potash mineralization that formed through a process of evaporation. Halokinetic potashbearing salt deposits (appendix B) form from stratabound deposits through deformation of salt layers into salt structures such as anticlines, domes, and diapirs. In these deposits, the thickness of the potash-bearing layer varies along different parts of structures or pinches out completely, and bedding is commonly highly contorted. In addition, tracts are delineated for areas underlain by potash-bearing brines that are actively producing potash or are undergoing potash exploration and evaluation. Figures 3-2 and 3-3 show the frequency and distribution, respectively, of tracts by deposit type in bar chart form and on a world map. The deposit type labeled as Mixed is applied to tracts that contain both the stratabound and halokinetic deposit types or have features related to both types of deposits. The Evaporite category is used for the Priaralian tract, located west of the Aral Sea in Kazakhstan, where sylvite has been reported but no other information is known.

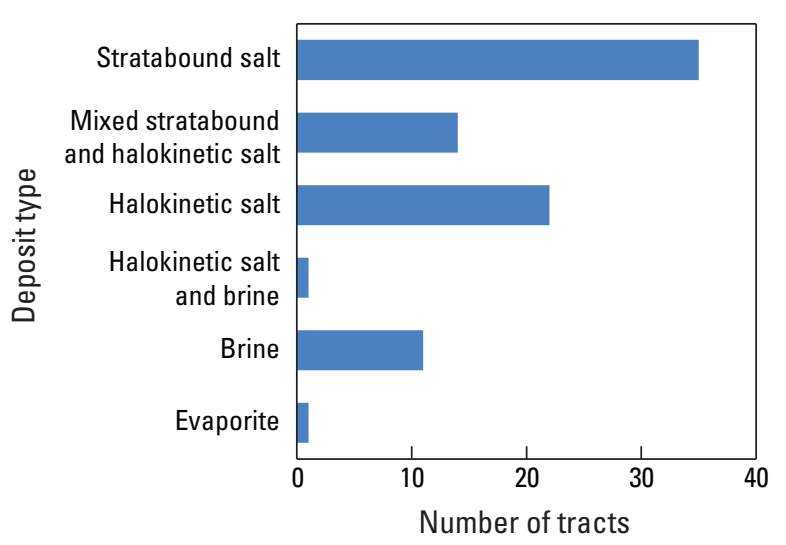

Figure 3-2. Graph showing distribution of deposit type classifications for 84 potash tracts. 

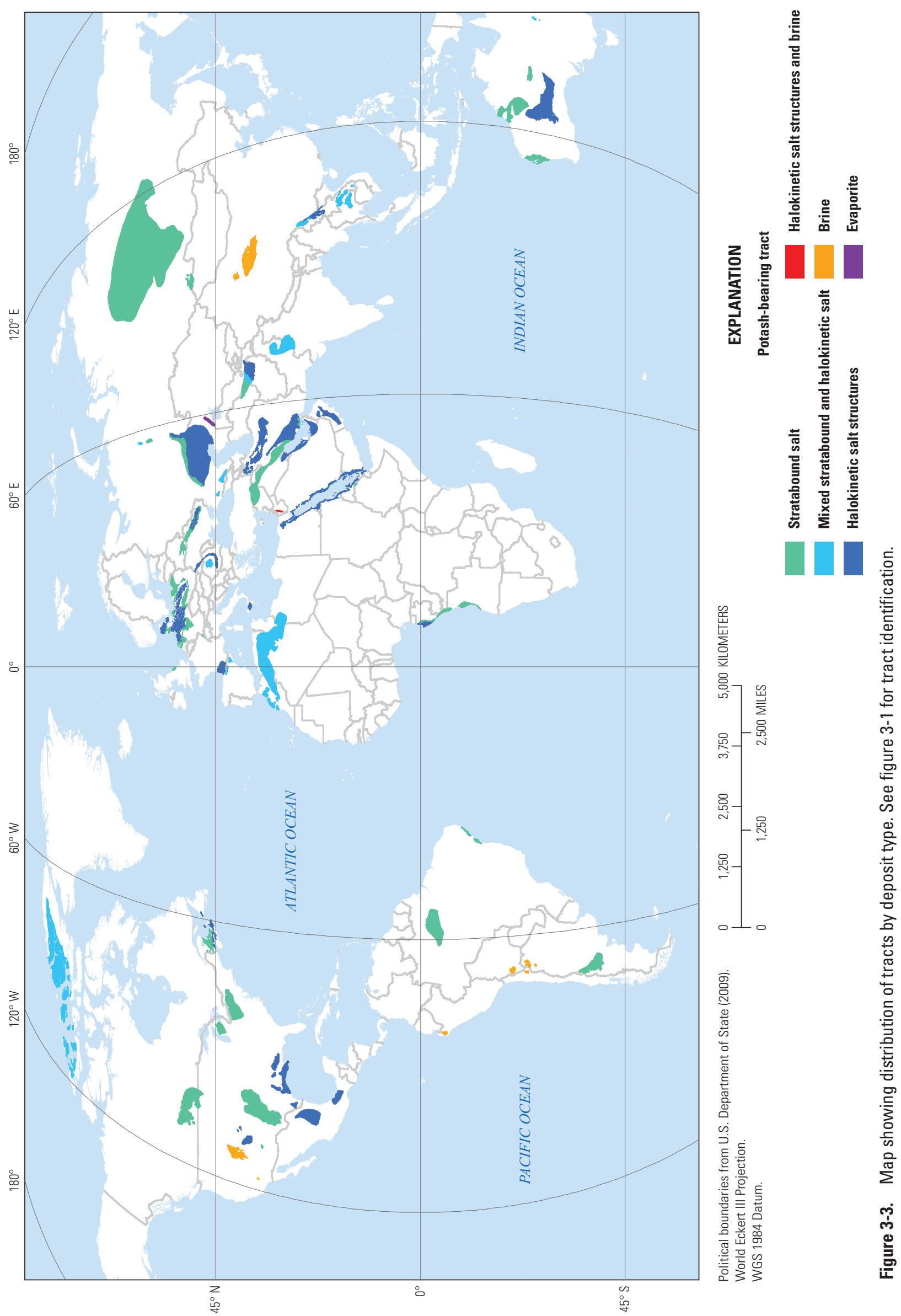
Current potash production is dominated by stratabound potash-bearing salt deposits, including mines in the Elk Point, Solikamsk, and Pripyat tracts. These deposits tend to be more continuous and have more consistent depths and thicknesses than halokinetic deposit types and, therefore, are a more predictable mining environment. Despite this, the inventory of known resources is relatively evenly divided between the stratabound tracts and the halokinetic and mixed tracts, although production favors deposits not affected by halokinesis. Data compiled for this study indicate the existence of significant known resources in halokinetic potashbearing salt deposits, especially within the Pricaspian and Gissar tracts, where the total reported known resources in each tract exceed 20 billion metric tons.

Halokinetic potash-bearing salt deposits, such as many of those in the Pricaspian tract (fig. 3-4), can have resources similar in size to stratabound deposits, but in some places halokinesis may have disrupted and (or) dissolved potash mineralization or led to highly variable thicknesses and deposit orientations. For example, salt flow can thin potash beds or lead to fractures in overlying rocks which can provide pathways for water that can dissolve the deposits. In contrast, the process of halokinesis can also impart beneficial characteristics to potash deposits. Halokinesis can move deposits closer to the surface, cause local thickening of horizons, or locally convert carnallite to sylvite, which is commonly considered to be the potash "mineral of choice" (Gimm, 1968; Korin, 1992; Roth, 1972). Many of the deposits reported under development in the last few years are from halokinetic or probable mixed halokineticstratabound tracts. These include the mine at Tyubegatan, Uzbekistan, in the Gissar tract, and the ongoing development efforts by Asia Pacific Corp. and Chinese-Laotian concerns within the Sakon Nakhon tract in Thailand and Lao People's Democratic Republic.

Most potash occurs in basins that can be classified as intracratonic (fig. 3-5) in cratonic settings; potash deposits and their host tracts in intracratonic basins tend to be more areally extensive than in other types of basins. This supports previous observations by Warren (2010) and Zharkov (1981). In contrast, in rift basins and tectonic settings with active faulting and subsidence, salt and potash deposits are thicker, have more elongated shapes, and have a greater tendency to develop salt structures than deposits in other tectonic basin settings.

Polyhalite, a sulfate mineral, was not identified in any tract that did not contain halite and more soluble potash minerals, although there were some concerns early in the assessment process that halite would not always be a significant component of the evaporite sequences hosting polyhalite mineralization. In some basins, polyhalite is found in distinctly different (sulfate) horizons as described in the literature (Peryt and others, 2005) or occupies the periphery of potash mineralized areas. In other basins, areas of polyhalite mineralization are not distinct from sylvite-carnallite mineralization and are likely intermixed. In all cases, halite is a significant component of the evaporite sequence hosting potash mineralization.

Overall, potash resources appear to be widely distributed, although potash does not occur in every salt-bearing basin. On the basis of this compilation of potash resources, fewer than half of the salt basins identified by Warren (2010) and Zharkov (1984) have any reported potash and half of the potash-bearing salt basins may not have potential for potash production. Of the tracts delineated in this study, 40 contain potash deposits of sufficient size and grade to be of some economic interest. However, many of these tracts have negative geologic or economic factors, such as a lack of transportation or other infrastructure, that decrease the possibility of potash occurring or the possibility of extraction if potash is present. Many potential potash resources outside of large producing areas in Canada, Belarus, and Russia are not of sufficient size to affect the global market, but some could provide significant economic resources at a regional level.

The most significant finding of this global potash study is that there appears to be little to no potential for development of conventional potash mines (sylvite and carnallite) in either China or India, where the scale of agricultural production required to feed large populations creates high demand for fertilizers. Neither China nor India has significant deposits of potash-bearing salt and their potash demand grew at a rate of 8 percent (double the world average) between 1993 and 2008 (Carr, 2011). Known salt deposits in India are old (Neoproterozoic-Cambrian), and soluble potash salts are likely to have been destroyed over such a long geologic interval. In addition, in areas where potash is known to occur, mineralization is dominated by polyhalite, and grades average between 5 and 6 percent $\mathrm{K}_{2} \mathrm{O}$ (Kumar and Bakliwal, 2005). Known potash-bearing salt deposits in China are found in the Mengyejing district of the Yunnan Province. These producing deposits, of probable Late Cretaceous to Paleocene age, are small and relatively low grade (Shuai, 1993; Yuan and others, 1996) compared to most other currently producing potash deposits. The Mengyejing deposits were subjected to intense compression, deformation, and metamorphism at the end of the Eocene (Shuai, 1993), which reduced the size and grade of producing deposits. In recent years, geologically young brinedominated deposits have been discovered and brought into production in China; these are dominated by the large brine deposits in the Tarim and Qaidam basins of western China that contain potash and other commodities such as boron, lithium, and magnesium (Wang and others, 2005; Yuan and others, 1996; Zheng and Liu, 2009). These resources, however, are insufficient to meet China's internal need, and potash exploration efforts to date have not resulted in identification of any other significant potash resources. New deposits in Central Asia and Thailand are well placed to effectively compete against North American sources in Chinese and Indian markets. 


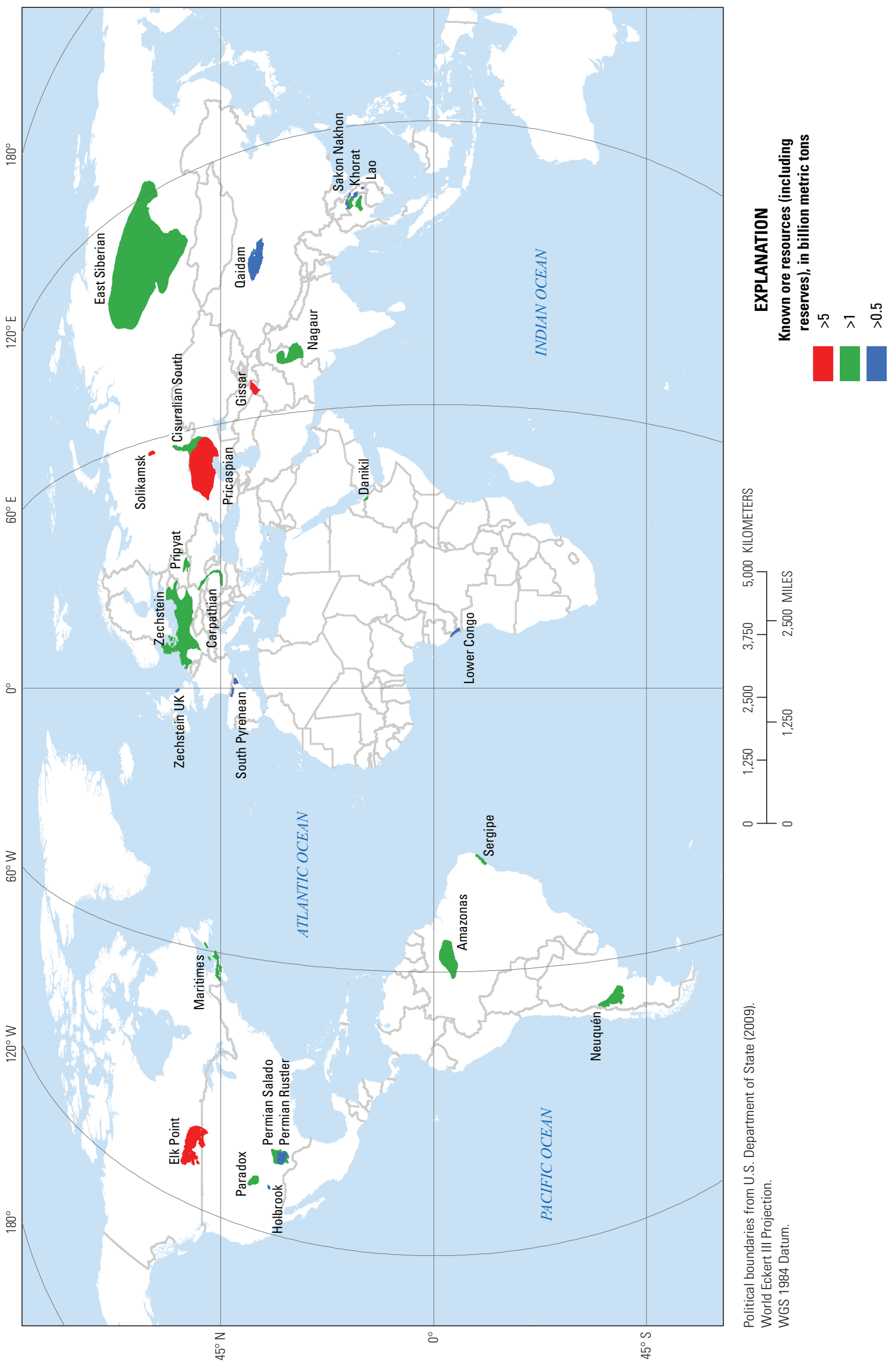

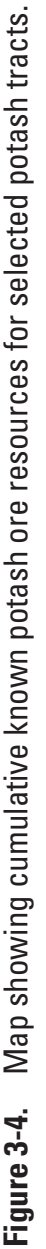




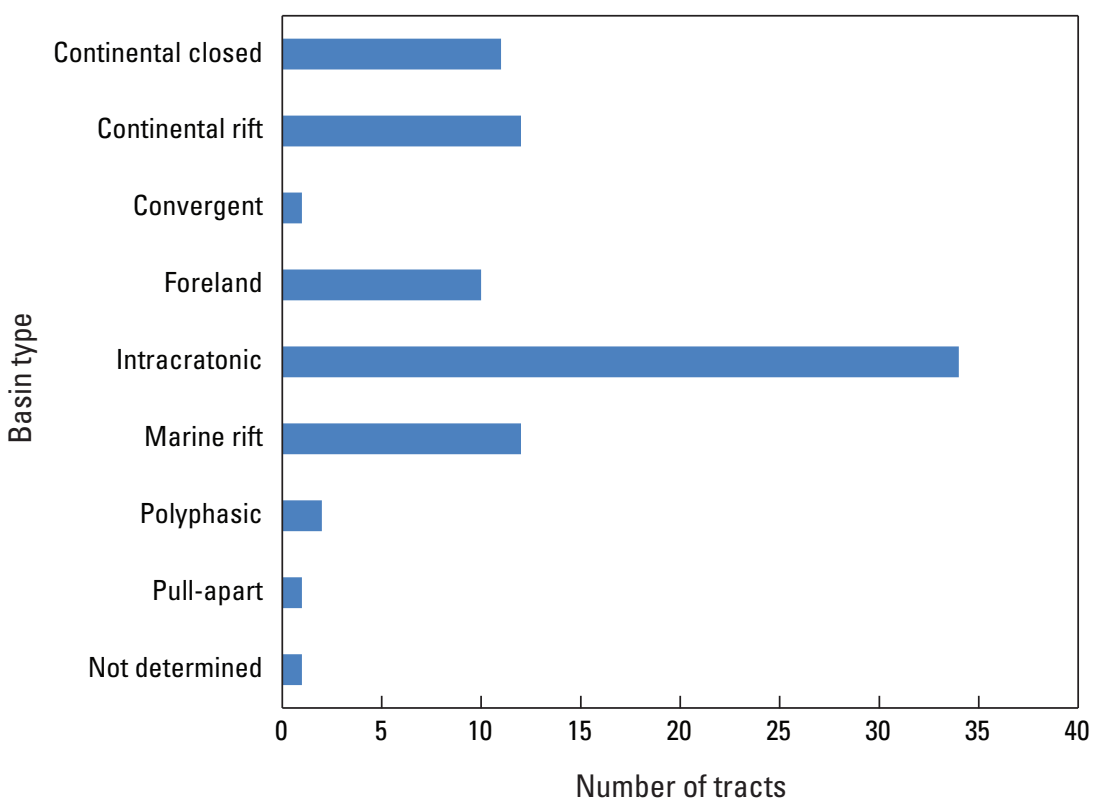

Figure 3-5. Graph showing distribution of basin type classifications for 84 potash tracts.

\section{Potash Tracts Database Fields}

The potash tracts database is available in multiple file formats as described in chapter 4. As with the deposits database, data fields and their descriptive information are the same in all formats, except for Esri-defined fields that occur only in the GIS version (table 2-3). Graphics are available for some tracts and accessible from within the GIS data files or as PDF files included with the digital files of this report (see chapter 4). For the Esri file geodatabase version of the potash tracts database, references can be accessed interactively, but are also available in the "Tracts GeologyRefs relate table" worksheet included in PotashTracts.xlsx descriptive data file (Excel workbook); this is described in chapter 4 and appendix E.

Data fields in the potash tracts database include:

Field Descriptor (Field Name): Short definition. Additional explanatory information.

Data fields in the potash tracts database include:

Identification Number (TRACT_ID): Unique numeric identifier for each tract.

Coded Identifier (Coded_ID): Coded, unique identifier assigned to permissive tract. Constructed using United Nations regional code (table 3-2), a deposit type code (table 2-1), commodity, and a unique number. May be followed by a letter where multiple tracts are defined for related mineralization within a single basin.
Tract Name (Tract_name): Informal name of the permissive tract. This name is commonly the host basin name, a variant of the basin name, a subbasin name, or the name of a prominent geologic feature. A list of potash tracts can be found in table 3-1.

U.N. Regional Code (Unregcode): Three digit United Nations code for the region that underlies most of the permissive tract (table 3-2). This code may appear as a single digit if there are preceding zeros. The source of the code is the UN standard country or area codes for statistical use; specifically, codes for macro-geographical (continental) regions, geographical subregions, and selected economic and other groupings (United Nations, 2011).

Country (Country): Country(s) in which permissive tract is located; multiple countries are listed alphabetically and are hyphen-delimited.

Table 3-2. United Nations regional codes used for Coded_IDs in the global potash database.

[United Nations regional codes from United Nations, 2011]

\begin{tabular}{cl}
\hline Code & \multicolumn{1}{c}{ Region } \\
\hline 002 & Africa \\
003 & North America \\
005 & South America \\
009 & Oceania \\
142 & Asia \\
150 & Europe \\
\hline
\end{tabular}


Commodity (Commod): Primary commodity assessed. For all tracts in this report, $\boldsymbol{K}$ is listed in this field for potash or potassium. $\boldsymbol{K}$ is not necessarily the most economically significant commodity; it is only an indication that the tract is being evaluated for potash

Deposit Type (Dep-type): Potash deposit type(s) most likely to be present. Deposit types are listed in table 2-1. One tract contains both potash-bearing brine and the potential for halokinetic potash-bearing salt (tract 58, table 3-1). Brines may occur with any deposit type and may be either the same age as any salts being assessed or significantly younger; that is, the brines may be a remnant of the original mineralizing process, they may be a result of dissolution of stratabound or halokinetic potash-bearing salt, or they may have formed in a modern evaporite setting independent of older salt deposits. Therefore, not all potash deposits and occurrences that occur within or near tract boundaries are necessarily related to the deposit type(s) being assessed. A difference in age is the easiest way to resolve an apparent conflict between a delineated tract and a potash deposit or occurrence that plots within or near a tract.

Tectonic Setting (Tect_Set): The dominant tectonic setting at the time of salt and potash deposition; queried where uncertain. The simplified tectonic settings used in this report are given in table 2-4. While a clear classification is reported or can be determined for most tracts, for other tracts, such as the Pricaspian tract, the potash mineralization is a function of a series of formational environments and any single choice does not fit the style of mineralization well. In this case, polyphasic is used for the tectonic setting.

Basin (Basin): Evaporite basin containing known or hypothesized potash mineralization. The basin name most appropriate for the extent of known or hypothesized potash mineralization is listed in this field. For additional explanation, the reader is referred to the description of the Basin field in the potash deposits and occurrences database (chapter 2).

Basin type (Basin_type): Type of sedimentary basin; queried where uncertain. This field contains basin types (listed in table 2-4) that most appropriately describe the basinal environment in which the potash was deposited for each tract.

Geologic Era (Age_Era): Geologic era(s) of potash mineralization; multiple terms are hyphen-delimited. If an age range is needed, all eras from oldest to youngest are listed in chronographic order. Unknown is listed in this field for the tract where we do not know the age (tract 61, table 3-1). Eras are defined based on the International Stratigraphic Chart (International Commission on Stratigraphy, 2010).
Geologic Period (Age_Period): Geologic period(s) of potash mineralization; queried where uncertain; multiple terms are hyphen-delimited. If an age range is needed, all periods from oldest to youngest are listed in chronographic order. Periods are defined on the International Stratigraphic Chart (International Commission on Stratigraphy, 2010).

Square brackets enclosing the phrase no defined period are used to anchor an age range where no epoch is defined for one end of the range; for example, [no defined period]Cambrian is used where no epochs are defined for the Neoproterozoic. Field contains no entry if period is not known.

Geologic Epoch (Age_Epoch): Geologic epoch(s) of potash mineralization; queried where uncertain; multiple terms are hyphen-delimited. If an age range is needed, all epochs from oldest to youngest are listed in chronographic order. Epochs are defined on the International Stratigraphic Chart (International Commission on Stratigraphy, 2010). Square brackets enclosing the phrase no defined epoch are used to anchor an age range where no epoch is defined for one end of the range; for example, [no defined epoch]Lower Cambrian is used where no epochs are defined for the Neoproterozoic. Field contains no entry if epoch is not known.

Geologic Stage (Age_Stage): Geologic stage(s) of the assessed potash-bearing evaporite; queried where uncertain; multiple terms are hyphen-delimited. If an age range is needed, all stages from oldest to youngest are listed in chronographic order. Square brackets and the word recent are used to anchor an age range where one end of the range does not have a stage name; for example, Upper Pleistocene-[recent]. As with the Geologic Epochs field, stages are given in units as defined on the International Stratigraphic Chart (International Commission on Stratigraphy, 2010). Field contains no entry if stage is not known.

Oldest Age (Age_Max): Oldest age of potash mineralization; queried where uncertain; presented as a hyphen-delimited concatenation of geologic era, followed by geologic period, epoch, and stage, where known. Unknown indicates age is not known. Terms are defined based on the International Stratigraphic Chart (International Commission on Stratigraphy, 2010).

Youngest Age (Age_Min): Youngest age of potash mineralization; queried where uncertain; presented as a hyphen-delimited concatenation of geologic era, followed by geologic period, epoch, and stage, where known. Unknown indicates geologic age is not known and queried terms are uncertain. Terms are defined based on the International Stratigraphic Chart (International Commission on Stratigraphy, 2010). 
Host Rock Unit (Unit): Host rock unit in which potash mineralization occurs; multiple units are commadelimited and subunits are hyphen-delimited. Field includes formal or informal names of the host units as reported by data sources. If a name does not exist or is not known, then not identified is entered in this field.

Known Potash Site (K_sites): Presence or absence of sites with known potash mineralization that are listed in the potash deposits and occurrences database (see chapter 3). Yes is listed if there are one or more sites in the deposits and occurrences database that would fall within this tract and are not young playa or sabkha brines; No if not.

Potash Minerals (K_minerals): Potash mineral(s) or ore material(s) known to occur within the tract, listed in approximate order of abundance. Table 2-2 contains a list of the potash minerals with their compositions and specific gravities. Mineral names are used in this field within the geodatabase, with the exception of general ore material terms such as brine. These ore material terms are listed and defined in table 2-2.

Mining Activity (Mining_act): Presence or absence of potash mining or development activity; queried where uncertain. Four responses are present: Yes, No, Under development, and Under development(?). If potash production of any size has occurred at any time within the tract from the deposit type being assessed, Yes is present in this field. $N o$ is listed if there is no production reported. Under development is listed in this field if a site within the tract is reportedly being developed at the time of this report and potash production will begin a relatively short time. Where there are conflicting reports on whether a site within the tract was being developed, Under development(?) is listed in this field.

Exploration Activity (Explor_act): Presence or absence of potash exploration or development activity about or after the year 2000; queried where uncertain. Yes is listed if exploration or development has occurred in that period; No if it has not.

Identified Potash Resources (Resources): Presence or absence of reported tonnage and grade information for one or more deposits or areas within the tract. Yes is listed if we have found information; No if we have not.

Delineated Feature Type (Delin_feat): The type of geologic feature(s) used to define the extent of the tract; multiple values are comma-delimited. A term selected from a hierarchical list (basin, potash, salt, salt structures, or unit) that best describes the feature represented by the tract polygon. The term unit is used for a geologic formation, lithology, or other unit that can be distinguished on a geologic map. A tract may list more than one feature type if information for more than one type of feature is used to define the tract; for example, the Afghan-Tajik tract was initially delineated using a combination of basin boundaries and occurrences of salt structures.

Geologic Summary (Geology): A brief description of the geology of the tract with an emphasis on identifiable features related to the potential for potash mineralization.

Tract Delineation Description (Tract_desc): A description of the process used to delineate the tract, such that another person with similar experience could reproduce the areal extent of the tract given the same starting materials.

Short References (Short_refs): Abbreviated citation(s) for source reference(s) used in compiling the data; multiple citations are delimited by semicolons. Full references can be accessed through the GIS (see chapter 4) and are listed in the "References Cited" worksheet included in PotashTracts.xlsx descriptive data file that accompanies the spatial database.

Level of Information (Info_code): Qualitative ranking of the amount, quality, and map scale of available data and of our confidence in it. Tracts are subjectively ranked from $\boldsymbol{A}$ (abundant information) to $\boldsymbol{F}$ (very little or no information) on the basis of the quantity, quality, type, and scale of the data available for the tract and any known salt or potash mineralization. Incomplete is listed for a few tracts that were not fully addressed by the current effort. Levels $\boldsymbol{A}, \boldsymbol{C}$, and $\boldsymbol{E}$ are defined explicitly. Levels $\boldsymbol{B}$ and $\boldsymbol{D}$ are not explicitly defined because they are used for amounts of information between those in levels $\boldsymbol{A}$ and $\boldsymbol{C}$, and levels $\boldsymbol{C}$ and $\boldsymbol{E}$, respectively. Tracts ranked $\boldsymbol{A}$ have dozens of articles and (or) books (commonly more than 30) that describe potash mineralization details and the geologic setting in which it occurs. These tracts typically have detailed, located point data and (or) facies maps that define the extent of mineralization and other details, such as thickness or grade variability. Lesser amounts of information (commonly fewer than 20 sources) are available for tracts ranked $\boldsymbol{C}$ and detailed information is limited or is not tied to specific location. Tracts ranked $\boldsymbol{E}$ have ten references with virtually no details or point information. Tracts ranked $\boldsymbol{F}$ have little or no information beyond potash being known or postulated to occur and, possibly, regional geologic information. Again, categories $\boldsymbol{B}$ and $\boldsymbol{D}$ represent levels of information that fit between categories $\boldsymbol{A}$ and $\boldsymbol{C}$ or $\boldsymbol{C}$ and $\boldsymbol{E}$, respectively. 
Assessment Year (Asmt_year): Year assessment was conducted.

Assessment Depth (Asmt_depth): Maximum depth beneath the Earth's surface used for resource assessment. For potash, this depth was established at $3 \mathrm{~km}$.

Resource Rank (R_rank): Two-character code for qualitative ranking of resources (table 3-3).

Assessors (Assessors): The person or team of people who assessed the potash potential for the tract or the area containing the tract. The participants of each team and the areas evaluated by each team are shown in table 3-4.

Comments (Comments): Modifying comments related to the Resource Rank field or any of the geologic fields.

Tract Area (sq. km) (Area_km²): Areal extent of tract, rounded based on scale of source maps; calculated using an equal area map projection.

Other Fields. Additional fields in the summary are for categorization of available graphics, such as cross sections and stratigraphic columns. Each graphic type has a unique attribute table heading; these are shown in table 3-5. Each graphic file has a 3-4 character tract code (table 3-6), followed by graphic type, by a letter if there are multiple graphics of one type, and additional information if needed. For example, a cross section for the Kwanza tract would be called "KWN_Cross_Sect.pdf."
Table 3-3. Ranking levels for potash tracts.

\begin{tabular}{cl}
\hline Rank & \multicolumn{1}{c}{ Description } \\
\hline R1 & $\begin{array}{l}\text { Tract contains undiscovered resources with potential for } \\
\text { economic development }\end{array}$ \\
R2 & $\begin{array}{l}\text { Tract contains undiscovered potash resources, but } \\
\text { some mineral economic factors are negative; mineral } \\
\text { economic factors include availability of power, poor } \\
\text { transportation infrastructure, knowledgeable workforce, } \\
\text { or other factors }\end{array}$ \\
R3 & $\begin{array}{l}\text { Tract contains undiscovered potash resources, but one } \\
\text { or more significant geologic factors may prevent } \\
\text { economic development; geologic factors could include } \\
\text { structure, type or style of potash mineralization, } \\
\text { hydrology, non-ore minerals or elements that could } \\
\text { pose processing or environmental problems, or other } \\
\text { geology-related issues }\end{array}$ \\
R4 & $\begin{array}{l}\text { Tract probably contains undiscovered potash resources, } \\
\text { but both mineral economic and geologic issues are } \\
\text { present that would inhibit development }\end{array}$ \\
Tract may contain undiscovered potash resources, but \\
R6
\end{tabular}

Table 3-4. Potash assessment teams.

[BGR, Bundesanstalt für Geowissenschften und Rohstoffe; BRGM, Bureau de Recherches Géologiques et Minières; CCOP, Coordinating Committee for Geoscience Programmes in East and Southeast Asia; USGS, United States Geological Survey]

\begin{tabular}{cll}
\hline Team & \multicolumn{1}{c}{ Participants } & \multicolumn{1}{c}{ Area(s) } \\
\hline A & $\begin{array}{l}\text { Karen S. Bolm, Joseph A. Briskey, Lawrence J. Drew, Bruce R. Lipin, } \\
\text { Greta J. Orris, Stephen G. Peters, Gregory T. Spanski (USGS) }\end{array}$ & Australia \\
B & $\begin{array}{l}\text { Stephen G. Peters (USGS); Wudhikarn Sukserm, Pairatt Jarnyaharn, } \\
\text { Pichai Otarawanna, Boonsong Yokart, Sompob Wongsomsak, Sieng Sotham, }\end{array}$ & Southeast Asia (Thailand) \\
& Nguyen Van Quy, I.M. Sim (CCOP) & Western Europe \\
C & Simone Röhling (BGR); Ignace Salpeter (BGRM); & Rest of world \\
& Walter J. Bawiec, Bruce R. Lipin, Greta J. Orris (USGS) & \\
D & Robert J. Ryan (Nova Scotia Department of Natural Resources); & \\
& Mirosław Słowakiewicz (Polish Geological Institute); & \\
& Yang Chao (Saskatchewan Geological Survey); & James D. Bliss, Mark D. Cocker, Pamela Dunlap, Bruce R. Lipin, \\
& Steve Ludington, Greta J. Orris, Gregory T. Spanski, Jeff Wynn (USGS) & Central Asia, Africa \\
\hline
\end{tabular}


Table 3-5. Additional attribute fields for categorization of available graphics.

\begin{tabular}{lll}
\hline \multicolumn{1}{c}{ Field descriptor } & Field name & \multicolumn{1}{c}{ Definition } \\
\hline Geologic Cross Section(s) & Cross_Sect & $\begin{array}{l}\text { Geologic cross section(s), in PDF format; } \\
\text { includes path name }\end{array}$ \\
Stratigraphic Section(s) & Strat_Sect & $\begin{array}{l}\text { Stratigraphic section(s) or column(s), in PDF format; } \\
\text { includes path name }\end{array}$ \\
Other structures & Str_other & $\begin{array}{l}\text { Maps or graphics showing other structures, in } \\
\text { PDF format; includes path name }\end{array}$ \\
Salt Extent & Salt_extent & $\begin{array}{l}\text { Map showing extent of salt, in PDF format; } \\
\text { includes path name }\end{array}$ \\
More Figures & More_figs & More figures, in PDF format; includes path name \\
\hline
\end{tabular}

Table 3-6. Naming codes used for graphics files.

\begin{tabular}{|c|c|c|c|}
\hline Tract, area, or basin name & $\begin{array}{c}\text { Graphic } \\
\text { location code }\end{array}$ & Type of graphic & $\begin{array}{c}\text { Graphic } \\
\text { code }\end{array}$ \\
\hline Amazonas & $\mathrm{AMZ}$ & Cross section & CrossSect \\
\hline Amu Darya & AMUD & Horizontal section & HorizSect \\
\hline Carpathian & CAR & Map & Map \\
\hline Dnieper-Donets & DD & Potash extent & KExtent \\
\hline Dnieper-Donets, Devonian & DD_Dev & Salt extent & SaltExtent \\
\hline Elk Point tracts, all & $\mathrm{EPT}$ & Stratigraphic section & StratSect \\
\hline Gabon South halokinetic & GABA & Structure-salt & SaltStr \\
\hline Gissar & GSR & Structure - other & StrOth \\
\hline Holbrook & HOL & Thickness isopachs & Thick \\
\hline Khorat + Sakon Nakhon + Lao & KHORALL & & \\
\hline Kwanza & KWN & & \\
\hline Lower Congo North & CNGA & & \\
\hline Lower Congo North and South & CNGAB & & \\
\hline Maritimes halokinetic & MARA & & \\
\hline Oman & $\mathrm{OMN}$ & & \\
\hline Paradox & PDX & & \\
\hline Permian-Salado & PRMS & & \\
\hline Pricaspian & PRIC & & \\
\hline Pripyat & PRIP & & \\
\hline Red Sea & RED & & \\
\hline Rhine Graben & RHIN & & \\
\hline Sicily & SLY & & \\
\hline Solikamsk & SOL & & \\
\hline Zechstein Glückstadt & ZCHA & & \\
\hline Zechstein Glückstadt + halokinetic + stratabound & ZCHABE & & \\
\hline Zechstein halokinetic & $\mathrm{ZCHB}$ & & \\
\hline Zechstein Denmark & ZCHF & & \\
\hline Zechstein United Kingdom & $\mathrm{ZCHG}$ & & \\
\hline
\end{tabular}




\section{GIS Data}

Digital data for the potash tracts data are available in the GIS files that accompany this report. Additional descriptions of the GIS files and information on accessing these files are given in chapter 4 and appendixes $\mathrm{E}$ and F. Full references for the potash tracts database are accessible when using the GIS (see chapter 4) and are listed in the "References" column of the "References Cited" worksheet included in PotashTracts. xlsx descriptive data file included with this publication.

\section{Summary}

The USGS database of potash tracts identifies potash resources in many parts of the world. The sizes of the tracts and their host basins vary several orders of magnitude: tracts for the stratabound and halokinetic potash-bearing salt deposits range in size from less than $2,000 \mathrm{~km}^{2}$ to more than $1,000,000 \mathrm{~km}^{2}$. In most tracts, carnallite or polyhalite are more prevalent than sylvite, although sylvite might be locally enriched within a given tract or basin. A majority of the tracts have not been explored or are incompletely explored, information from oil and gas or other exploratory drilling is erratic, and geophysical data for the subsurface are rare and incomplete. Many tracts are in areas where nongeologic deficiencies, such as lack of water, power, or other infrastructure, could prevent or delay development of deposits. Despite data inadequacies, it is clear from the limited known geology and the potash exploration of recent years that many of these tracts have the potential to host undiscovered potash deposits that could be of regional importance. 
This page intentionally left blank. 


\title{
Chapter 4. Spatial Databases for Evaporite-Related Potash Deposits, Occurrences, and Permissive Tracts Around the World
}

\author{
By Pamela Dunlap1, Deborah A. Briggs², and Leila Gass
}

\section{Introduction}

Spatially referenced distribution data on potash deposits and occurrences and related geologic features are necessary components for modern mineral resource assessments. Spatially referenced data on potash deposits, occurrences, and tracts are most effective in the resource assessment process when used together with other spatial data in a geographic information system (GIS).

The file geodatabase, USGS_Global_Potash.gdb, and ArcMap map document, Potash_Deposits_and_Tracts. mxd, were developed for use in version 10.2 or higher of Esri ArcGIS software. Terminology specific to ArcGIS is used throughout this report and the most commonly used terms are defined in table 4-1. Additionally, a dictionary of GIS-related terms and concepts is available at http://support.esri.com/en/ knowledgebase/Gisdictionary/browse.

\section{Overview of Digital Data Files}

Two spatial databases are stored as feature classes (Potash_Deposits, Potash_Tracts) in a feature dataset (Evap_Potash) (table 4-2). These data and associated nonspatial tables and relationship class files are packaged in an Esri file geodatabase (USGS_Global_Potash.gdb) and are ready to use in an ArcMap map document (Potash_Deposits_ and_Tracts.mxd) along with a folder of supplemental figures.

Site location point data in the global potash geodatabase (USGS_Global_Potash.gdb) were derived from a variety of source maps, the smallest scale of which was about 1:1,000,000; thus, the potash deposit and occurrence data should not be used or portrayed at scales larger than 1:1,000,000 (for example, 1:500,000). Tract boundary polygons were digitized onscreen from georeferenced maps and (or) copied from vector GIS data. Scales of georeferenced maps ranged from 1:50,000 to 1:18,000,000; line widths on the smallest scale map digitized were slightly more than $0.5 \mathrm{~mm}$. Thus, tract boundary locations are accurate to within $\pm 10 \mathrm{~km}$ or more, depending on (1) how well paper maps were georeferenced, given the quality and amount of geographic information on the maps, and (2) the scale of the source maps. The lineage section of the metadata for tracts (Potash_Tracts metadata.pdf) identifies the source and scale of maps used to generate tract boundaries.

A complete suite of Esri-format GIS data is provided in a compressed archive file named PotashGIS.zip; KML files are in PotashKML.zip; and Excel spreadsheets are in PotashXL. zip. All compressed archive files are available on the Internet at http://dx.doi.gov/10.3133/sir20105090S.

\section{Spatial Databases, Data Files, and Relationship Classes}

Spatial databases contain a unique component for geometry; geographic shapes may be represented in vector format either as points, lines, or polygons using either geographic coordinates or coordinates specific to a particular map projection. Spatial databases for potash are provided in geographic coordinates (using the datum WGS 1984) as feature classes (table 4-2) in a feature dataset (Evap_Potash) within the file geodatabase named USGS_Global_Potash. gdb. Attribute tables for the feature classes include descriptive data for geology, mineral resources, production, and source references Supplemental non-spatial data tables and relationship classes (table 4-3) allow records in feature classes to be queried using the Identify tool in ArcMap to portray both a list of references used and representative figures.

Feature classes were exported to Esri shapefiles, and descriptive data from the feature classes were exported to Microsoft Excel workbooks, for ease of use in other GIS and database software, respectively; KML files were then derived from the shapefiles for use in Google Earth (table 4-4). Metadata provide information about the feature classes. Embedded metadata in Extensible Markup Language (XML) format can be viewed in ArcGIS 10. Metadata are also provided in standalone Adobe Portable Document Format (PDF) files (table 4-2).

${ }^{1}$ U.S. Geological Survey, Tucson, Arizona, United States.

${ }^{2}$ U.S. Geological Survey, Spokane, Washington, United States. 
Table 4-1. GIS terminology and concepts used in this report.

[Definitions modified from Esri (2012)]

\begin{tabular}{|c|c|}
\hline Term & Definition \\
\hline Attribute table & $\begin{array}{l}\text { A database or tabular file containing information about a set of geographic } \\
\text { features, usually arranged so that each row (record) represents a feature and } \\
\text { each column (field) represents one feature attribute. }\end{array}$ \\
\hline Datum & $\begin{array}{l}\text { The reference specifications of a measurement system, usually a system of } \\
\text { coordinate positions on a surface (a horizontal datum). }\end{array}$ \\
\hline Feature class & $\begin{array}{l}\text { A collection of geographic features with the same geometry type (such as } \\
\text { point, line, or polygon), the same attributes, and the same spatial reference. }\end{array}$ \\
\hline File geodatabase (FGDB) & A geodatabase stored as a folder of files. \\
\hline Geodatabase & $\begin{array}{l}\text { A database or file structure used primarily to store, query, and manipulate } \\
\text { spatial data. Geodatabases store geometry, a spatial reference system, } \\
\text { attributes, and behavioral rules data. }\end{array}$ \\
\hline Geographic coordinate system & $\begin{array}{l}\text { A reference system that uses latitude and longitude to define the locations of } \\
\text { points on the surface of a sphere or spheroid. }\end{array}$ \\
\hline Hyperlink & $\begin{array}{l}\text { A reference (link) from one point in an electronic document to another } \\
\text { document or another location in the same document. }\end{array}$ \\
\hline Layer file (LYR) & $\begin{array}{l}\text { A file with a .lyr extension that stores the path to a source dataset and other } \\
\text { layer properties, including symbology. }\end{array}$ \\
\hline Relationship & An association or link between two objects in a database. \\
\hline Relationship class & An item in the geodatabase that stores information about a relationship. \\
\hline Shapefile & $\begin{array}{l}\text { A vector data storage format for storing the location, shape, and attributes of } \\
\text { geographic features. A shapefile is stored in a set of related files (with the } \\
\text { extensions .dbf, .prj, .sbn, .sbx, .shp, .shp.xml, and .shx) and contains one } \\
\text { feature class. }\end{array}$ \\
\hline
\end{tabular}

Table 4-2. Description of feature classes in the feature dataset Evap_Potash.

\begin{tabular}{lll}
\hline \multicolumn{1}{c}{ Name } & \multicolumn{1}{c}{ Description } & \multicolumn{1}{c}{ Metadata file name } \\
\hline Potash_Deposits & $\begin{array}{l}\text { Feature class (points) for deposits and } \\
\text { occurrences of evaporate-related potash. }\end{array}$ & Potash_Deposits_metadata.pdf \\
Potash_Tracts & $\begin{array}{l}\text { Feature class (polygons) for tracts permissive } \\
\text { for evaporate-related potash. }\end{array}$ & Potash_Tracts_metadata.pdf \\
\hline
\end{tabular}


Table 4-3. Description of supplemental non-spatial data tables and relationship classes in the file geodatabase USGS_Global_Potash.gdb.

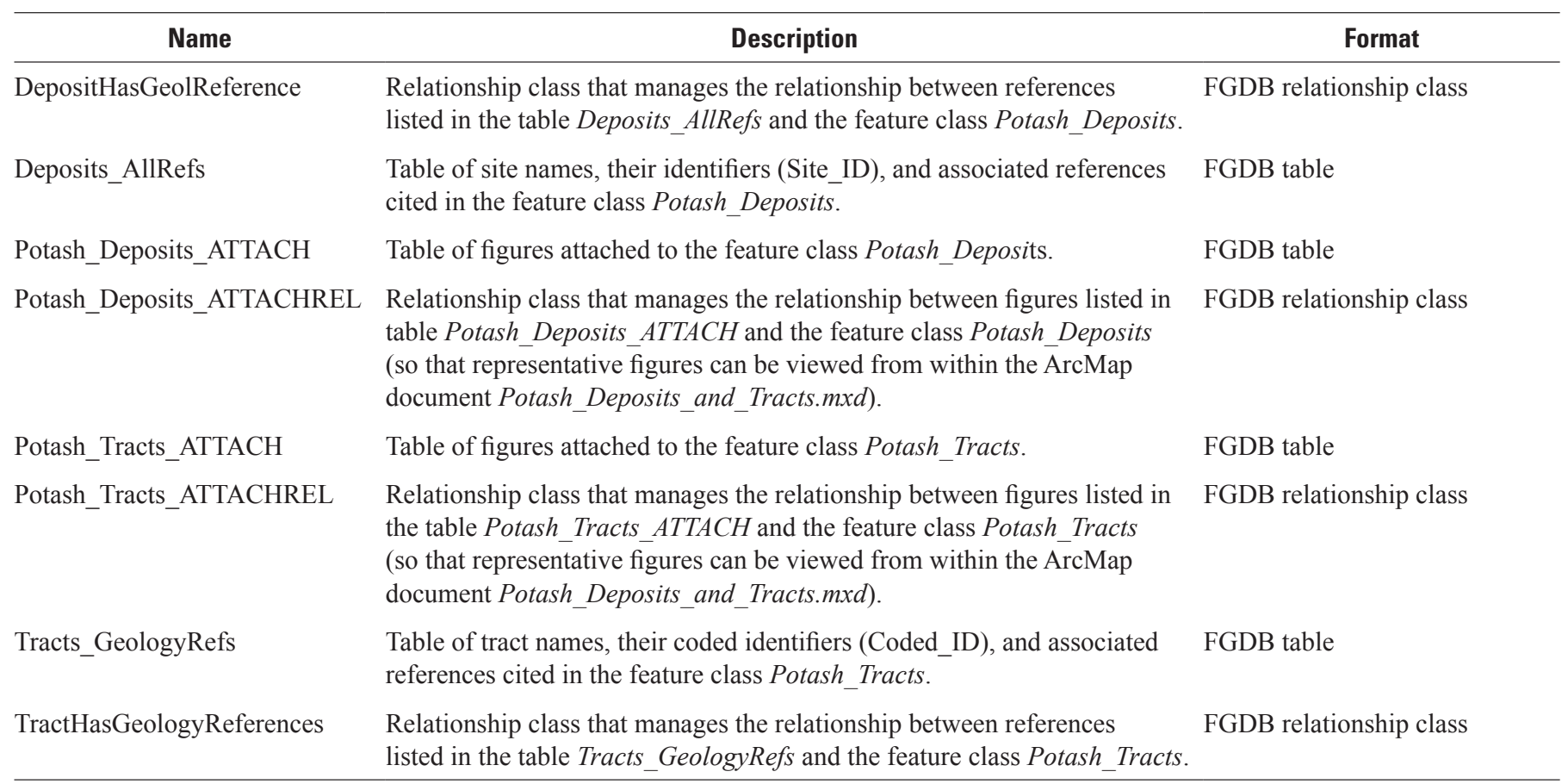

Table 4-4. Description of data files exported from the feature classes Potash_Deposits and Potash_Tracts.

\begin{tabular}{llc}
\hline File name (file name extensions) & Description & Format \\
\hline $\begin{array}{l}\text { PotashDeps }(* . \mathrm{dbf} / . \mathrm{prj} / . \mathrm{sbn} \\
\text { /.sbx/.shp/.shp.xml/.shx) }\end{array}$ & Spatial database (points) for potash deposits and occurrences. & Esri shapefile \\
Potash Deposits.kml & Spatial and descriptive data for potash deposits and occurrences. & Google Earth-compatible KML \\
PotashDeposits.xlsx & Descriptive data for potash deposits and occurrences. & Microsoft Excel 2010 \\
PotashTracts $(* . d b f / . p r j / . s b n$ & Spatial database (polygons) for potash tracts. & Esri shapefile \\
/.sbx/.shp/.shp.xml/.shx) & & Microsoft Excel 2010 \\
PotashTracts.xlsx & Descriptive data for tracts. & Google Earth-compatible KML \\
Potash Tracts.kml & Spatial and descriptive data for permissive tracts for potash. & \\
\hline
\end{tabular}




\section{Map Document Files, Layer Files, and Graphics Files}

The map document, Potash_Deposits_and Tracts.mxd, displays various pre-defined views of the spatial databases, source references from standalone tables that are attached to the feature classes and hyperlinked to source information on the Internet, and many graphics files that are attached and hyperlinked to records in the feature classes. Bookmarks are set to provide macroregional views of each continent. Esri layer files store predefined map symbols (and explanations) for the data. Layer files can be selected to view data by age, basin type, deposit type, feature name, and more. Layer files generated for the potash deposits and tracts feature classes are listed and described in tables 4-5 and 4-6, respectively.

Graphics files (in PDF format) can be viewed by using either the Identify or Hyperlink tools in the map document to hover over visible feature classes (turned on and zoomed in to a regional scale). Graphics files are listed and described in appendix E.

Table 4-5. Layer files for deposits and occurrences in the feature class Potash_Deposits.

\begin{tabular}{ll}
\hline \multicolumn{1}{c}{ File name } & \multicolumn{1}{c}{ Description } \\
\hline Deposits by Deposit Type LYR.lyr & Sites symbolized by deposit type. \\
Deposits by Geologic Epoch LYR.lyr & Sites symbolized by geologic epoch of host rocks. \\
Deposits by Geologic Era LYR.lyr & Sites symbolized by geologic era of host rocks. \\
Deposits by Geologic Period LYR.lyr & Sites symbolized by geologic period of host rocks. \\
$\begin{array}{l}\text { Deposits with primary ore minerals and } \\
\text { materials LYR.lyr }\end{array}$ & $\begin{array}{l}\text { Deposits symbolized for presence of primary ore minerals and materials } \\
\text { (specifically carnallite, kainite, langbeinite, polyhalite, sylvite, brine, }\end{array}$ \\
carnallitite, hartsalz, and sylvinite) \\
Deposits by Record Type LYR.lyr & Deposits symbolized by record type. \\
Deposits with Active Production LYR.lyr & Sites symbolized by site name. \\
Deposits with Past Production LYR.lyr & Sites symbolized for past production status. \\
Deposits with Reported Reserves and (or) & Sites symbolized for reported reserves and (or) resources. \\
Resources LYR.lyr & \\
\hline
\end{tabular}

Table 4-6. Layer files for permissive tracts in the feature class Potash_Tracts.

\begin{tabular}{ll}
\hline \multicolumn{1}{c}{ File name } & \multicolumn{1}{c}{ Description } \\
\hline Tracts by Activity and Identified Resources LYR.lyr & $\begin{array}{l}\text { Tracts symbolized by mining activity, exploration activity, } \\
\text { and identified resources. }\end{array}$ \\
Tracts by Basin Type LYR.lyr & Tracts symbolized by basin type. \\
Tracts by Deposit Type LYR.lyr & Tracts symbolized by deposit type. \\
Tracts by Geologic Epoch LYR.lyr & Tracts symbolized by geologic epoch of host rocks. \\
Tracts by Geologic Era LYR.lyr & Tracts symbolized by geologic era of host rocks. \\
Tracts by Geologic Period LYR.lyr & Tracts symbolized by geologic period of host rocks. \\
Tracts by oldest age rocks LYR.lyr & Tracts symbolized by oldest age of host rocks. \\
Tracts by Resource Rank LYR.lyr & Tracts symbolized by qualitative resource rank. \\
Tracts by Tectonic Setting LYR.lyr & Tracts symbolized by tectonic setting. \\
Tracts by Tract Name LYR.lyr & Tracts symbolized by name. \\
Tracts by youngest age rocks LYR.lyr & Tracts symbolized by youngest age of host rocks. \\
\hline
\end{tabular}




\section{Summary}

GIS data for global potash sites and tracts consists of an Esri file geodatabase (USGS_Global_Potash.gdb) and associated non-spatial files (appendix E). Figures (and tables of source references) are linked to features for easy viewing from within an ArcMap map document using ArcGIS 10. Detailed definitions and discussions of fields and values in the spatial databases for deposits and tracts are provided in chapters 2 and 3, respectively; brief definitions are in the metadata.

These databases can be queried to produce a variety of interpretive geologic maps and used to conduct quantitative potash-resource assessments. A brief set of instructions on how to use the data in ArcMap 10 is given in appendix F.

\section{Acknowledgments}

We would like to thank Simone Röhling (Bundesanstalt für Geowissenschften und Rohstoffe), Robert J. Ryan (Nova Scotia Department of Natural Resources), and Ignace Salpeter (Bureau de Recherches Géologiques et Minières) for their input to the geologic aspects of this report. We would also like to thank Stephen E. Box, Joseph A. Briskey, Lawrence J. Drew, Timothy S. Hayes, Steve Ludington, Stephen G. Peters, Gilpin R. Robinson, Klaus J. Schulz, and Cliff D. Taylor of the USGS for providing input and (or) oversight to the potash assessment effort. The authors are also grateful to Michael L. Zientek and Jane M. Hammarstrom of the USGS who have provided scientific and logistical guidance through the late stages of the USGS global potash study.

The potash study required a significant amount of GIS support. The assistance of Walter J. Bawiec (USGS) during early stages of our work was greatly appreciated. Robert J. Miller (USGS) provided dataset identification and graphics support. In addition, several contractors, including Craig Caton, Paul Denning, Joel P. Edgar, Shawna L. Ernst, Julie A. Johanson, Heather L. Parks, and John C. Wallis, assisted in rectifying and digitizing tract data for undiscovered potash. J. Douglas Causey (USGS) assisted in preparing a table of references used for the tracts. Additional GIS guidance was provided by Connie Dicken of the USGS.

We would also like to thank Pamela M. Cossette, Dan L. Mosier, and Gilpin R. Robinson of the USGS for their technical reviews of the manuscript and digital data.

\section{References Cited}

Abbott, D.M., and Kuchling, K.J., 2009, Encanto Potash Corp. and Angus Ventures Corp.-Technical report for Saskatchewan potash properties - Ochapowace/Chacachas prospect, T29, R5-6W2, latitude $50.48^{\circ} \mathrm{N}$, longitude $102.38^{\circ} \mathrm{W}$; Piapot/Muscowpetung prospect, T21, R17$18 \mathrm{~W} 2$, latitude $50.76^{\circ} \mathrm{N}$, longitude $104.27^{\circ} \mathrm{W}$; Day Star prospect, T29, R16W2, latitude $51.55^{\circ} \mathrm{N}$, longitude W104.27 $7^{\circ}$ : Toronto, Ontario, Behre Dolbear \& Company, Ltd., $47 \mathrm{p}$.

Agapito Associates, Inc., 2011, Satimola, Ltd.-Kazakhstan; potash and borate mine planning: Grand Junction, CO, Agapito Associates, Inc. Web page, accessed April 4, 2011, at http://www.agapito.com/2010/12/satimola-potash-andborate-mine-planning\%E2\%80\%94kazakhstan/.

Aguia Resources, 2012, Atlantic potash project, Brazil: Aguia Resources Web page, accessed March 6, 2012, at http:// www.aguiaresources.com.au//uploads/releases/120306 aguia_atlantic_potash_drilling_update_pac2.pdf.

Anthony, J.W., Bideaux, R.A., Bladh, K.W., and Nichols, M.C., 1997, Handbook of mineralogy, Volume III-Halides, hydroxides, oxides: Tucson, Ariz., Mineral Data Publishing, $628 \mathrm{p}$.

Anthony, J.W., Bideaux, R.A., Bladh, K.W., and Nichols, M.C., 2003, Handbook of mineralogy, Volume VBorates, carbonates, sulfates: Tucson, Ariz., Mineral Data Publishing, $813 \mathrm{p}$.

Atacama Minerals Corp., 2008, Atacama acquires major new potash project in Brazil: Vancouver, British Columbia, Atacama Minerals Corp. news release, July 14, 2008, 2 p., accessed December 9, 2008, at http:/cnrp.marketwire.com/ client/atacama_minerals/n/release.jsp?actionFor=878514.

Back, M.E., and Mandarino, J.A., 2008, Fleischer's glossary of mineral species 2008: Tucson, Ariz., The Mineralogical Record Inc., 344 p.

Belaruskali, 2011, Information on the constructing works of Beryozovski mine as of July 1, 2009: Belaruskali Web page, accessed August 30, 2011, at http://www.kali.by/english/ firm.html.

BHP Billiton, 2010, BHP Billiton announces mineral resource estimate for its Jansen potash project: BHP Billiton news release, June 7, 2010, 2 p., accessed June 26, 2010, at http://www.bhpbilliton.com/bb/investorsMedia/news/2010/ bhpBillitonAnnouncesMineralResourceEstimateForItsJanse nPotash-Project.jsp. 
BHP Billiton, 2011, Further investment in the Jansen Potash Project: BHP Billiton Web page, accessed August 2, 2011, at http://www.bhpbilliton.com/home/investors/news/Pages/ Articles/Further-Investment-in-the-Jansen-Potash-Project. aspx.

Blagov, Sergei, 2010, Turkmenistan, Belarus agree to new potash project: London, ICIS Web page, accessed January 22, 2011, at http://www.icis.com/ Articles/2010/01/26/9328721/turkmenistan-belarus-agreeto-new-potash-project.html.

Bout, J., and Chiang, K., 2008, Global potash supply-A focus on Saskatchewan exploration: Toronto, CIBC World Markets Inc., 70 p.

Bromby, Robin, 2011, The Central Asia factor: Potashblog Web page, accessed August 29, 2011, at http:/www. potashblog.com/2011/08/the-central-asia-factor.html\#tp.

Busby, Cathy, Azor, Antonio, Johnson, C.L., Ritts, B.D., 2012, Plate interior poly-phase basins, in Busby, Cathy, and Azor, Antonio, eds., Tectonics of sedimentary basins-Recent advances: Chichester, United Kingdom, John Wiley \& Sons, $642 \mathrm{p}$.

Butrenchuk, S.B., 2009, NI 43-101 Technical ReportHolbrook Basin potash project, 602550E $3847300 \mathrm{~N}$ in the 1983 North American Datum (NAD 83), for Passport Metals: Lethbridge, Alberta, 22 p., downloaded from Passport Metals Web page, accessed May 7, 2010, at http:// www.passportpotash.com/upload/Holbrook 43-101 27-Jan2009.pdf.

Campbell, M.D., and King, J.D., 2009, AusPotash Corporation Project_-Adavale Basin, Queensland, Australia, NI 43-101 Report for AusPotash Corporation, Toronto, Ontario, Canada: Houston, Tex., M.D. Campbell and Associates, L.P., 113 p.

Carr, Matthew, 2011, The potash industry poised for big returns as global demand rises: Investment $U$ Web page, accessed June 3, 2012, at http://www.investmentu. com/2011/May/potash-industry-demand.html.

CDM, 2011, New potash mine in the Perm region, Russia: CDM Web page, accessed September 13, 2011, at http:// www.cdm.com/en-EU/Solutions/Facilities/New-Potashmine-in-the-Perm-Region-Russia.aspx.

Chemical Business Newsbase, 2010, Eurochem heads toward potash market entry: AccessMyLibrary Web page, accessed March 25, 2011, at http://www.accessmylibrary.com/ article-1G1-237593897/eurochem-heads-toward-potash. html.
Chinese Academy of Sciences, 2011, ISL Expands technological shares in China-Laos Minerals Development and Investment Corp., in Newsroom: Chinese Academy of Sciences Web page, accessed September 9, 2011, at http:// english.cas.cn/Ne/ICN/201002/t20100206_50775.shtml.

Dajin Resources Corp., 2012, Boron/Lithium/Potash: Dajin Resources Corp. Web page, accessed February 22, 2012, at http://www.dajin.ca/lithium_potash/.

DeCellles, P.G., and Giles, K.A., 1996, Foreland basin systems: Basin Research, v. 8, p. 105-123.

Dorling, S., Elliott, J., Scogings, A., Davies, P., and Rigby, N., 2011, NI 43-101 Technical Report Sintoukola potash project, Republic of Congo; report prepared for Elemental Minerals Limited: Lakewood, Colo., and West Perth, Western Australia, SRK Consulting (U.S.), Inc. and CSA Global Pty. Ltd., 158 p. plus appendixes.

Einsele, Gerhard, 2000, Sedimentary basins-Evolution, facies, and sediment budget (2nd ed.): New York, Springer, $792 \mathrm{p}$.

Encanto Potash Corp., 2011a, Chacachas Prospect: Encanto Potash Corp. Web page, accessed April 24, 2011, at http:// www.encantopotash.com/english/projects1/firstnations/ chacachas/overview/default.aspx.

Encanto Potash Corp., 2011b, Ochapowace Prospect: Encanto Potash Corp. Web page, accessed April 24, 2011, at http:// www.encantopotash.com/english/projects1/firstnations/ ochapowace/overview/default.aspx.

Encanto Potash Corp., 2011c, Day Star Prospect: Encanto Potash Corp. Web page, accessed April 24, 2011, at http:// www.encantopotash.com/english/projects 1/firstnations/ daystar/overview/default.aspx.

Encanto Potash Corp., 2011d, Muskowekwan Prospect: Encanto Potash Corp. Web page, accessed April 24, 2011, at http:/www.encantopotash.com/english/projects1/ firstnations/muskowekwanprospect/overview/default.aspx.

Encanto Potash Corp., 2011e, Muscowpetung Prospect: Encanto Potash Corp. Web page, accessed April 24, 2011, at http:/www.encantopotash.com/english/projects1/ firstnations/muscowpetung/overview/default.aspx.

Esri, 2012, GIS Dictionary: Redlands, Calif., Esri Web page accessed March 12, 2012, at http://support.esri.com/en/ knowledgebase/Gisdictionary/browse.

EuroChem, 2010, 10 years of sustainable developmentSustainability report 2010: Moscow, EuroChem Mineral and Chemical Company, $97 \mathrm{p}$. 
Foreign Policy and Security Research Center, 2011, Belaruskali commissions second priority complex at Krasnoslobodsky mine: Minsk, Foreign Policy and Security Research Center Web page, accessed January 4, 2012, at http://forsecurity.org/belaruskali-commissions-secondpriority-complex-krasnoslobodsky-mine.

Fortis Mining Inc., 2011a, Chelkarskaya: Melbourne, Australia, Fortis Mining Ltd. Web page, accessed September 17, 2011, at http:/www.fortismining.com.au/ fortis_chelkarskaya.html.

Fortis Mining Inc., 2011b, Zhilyanskoe: Melbourne, Australia, Fortis Mining Ltd. Web page, accessed September 17, 2011, at http://www.fortismining.com.au/fortis_mining zhilyanskoe.html.

Garrett, D.E., 1996, Potash-deposits, processing, properties and uses: New York, Chapman \& Hall, 734 p.

General Mining Corporation Ltd., 2009, 2009 Prospectus: Perth, Australia, 13 p., downloaded from General Mining Corporation Ltd. Web page, accessed September 28, 2010, at http://generalmining.com.

Gimm, W., 1968, Kali- und Steinsalzbergbau; band 1, Aufschluss und Abbau von Kali- und Steinsalzlagerstaetten [Potash and rock salt mining; vol. 1, Exploration and exploitation of potash and rock salt deposits]: Leipzig, VEB Deutscher Verlag für Grundstoffindustrie, v. 1 of 2, 600 p.

GrowMax Agri Corp., 2011, Peru, GrowMax Agri Corp.Potash and minerals: Calgary, Alberta, GrowMax Agri Corp. Web page, accessed May 3, 2011, at http://www. growmaxagricorp.com/contact/contact-information.html.

Hains, D.H., 2011, Technical report on Salar de Maricunga lithium project, northern Chile; prepared for Li3 Inc.: Toronto, Ontario, Hains Technology Associates, 105 p.

Hammarstrom, J.M., Zientek, M.L., Orris, G.J., and Taylor, C.D., 2010, Global Mineral Resource AssessmentChallenges and opportunities for developing and refining assessment methods [abs.]: Geological Society of America Denver 2010 Annual Meeting Final Program Web page, accessed November 22, 2010, at http:/gsa.confex.com/ gsa/2010AM/finalprogram/abstract_178026.htm.

Handford, C.R., 1991, Marginal marine halite: Sabkhas and salinas, in Melvin, J.L., ed., Evaporites, petroleum and mineral resources: New York, Elsevier, p. 1-66.

Harben, P.W., 2002, Potassium minerals and compounds, in The industrial minerals handybook (4th ed.): Worcester Park, United Kingdom, Industrial Minerals Information, p. 264-272.

Harben, P.W., and Kuzvart, M., 1996, Industrial minerals - A global geology: London, Industrial Minerals Information Ltd., 462 p.
Hardie, L.A., 1991, On the significance of evaporites: Annual Review Earth and Planetary Sciences, v. 19, p. 131-168.

Hardie, L.A., 1996, Secular variation in seawater chemistryAn explanation for the coupled secular variation in the mineralogies of marine limestones and potash evaporites over the past 600 m.y.: Geology, v. 24, no. 3, p. 279-283.

Hardy, M., Halabura, S.P., and Shewfelt, D., 2009, Technical Report-2009 potash resource assessment for Subsurface Mineral Permit KP 289, Saskatchewan: Grand Junction, Colo., Agapito Associates, Inc. and North Rim Exploration Ltd., 163 p.

Hardy, M.P., Hambley, D.F., and Crawford, J.E., 2009, Updated technical report concerning subsurface mineral permit application KP 441, Langham area, Saskatchewan (prepared for Raytec Metals Corp. and Encanto Potash Corp.): Grand Junction, Colo., Agapito Associates, Inc., 92 p. plus appendixes.

Holle Potash Corporation, 2012, Manenga potash project (Republic of Congo): Longueuil, Quebec, Holle Potash Corporation Web page, accessed February 15, 2012, at http://www.hollepotash.com/_content/news/Holle_Potash_ Corp._-_February_2012.pdf.

Houston, J., 2010a, Technical report on the Salinas GrandesGuayatayoc project, Jujuy-Salta Provinces, Argentina; Report for NI43-101: Milton, Queensland, Orocobre Ltd., $80 \mathrm{p}$.

Houston, J., 2010b, Technical report on the Cauchari project, Jujuy Province, Argentina-NI 43-101 Report prepared for Orocobre Ltd.: Milton, Queensland, Orocobre Ltd., 70 p.

Houston, J., and Ehren, P., 2010, Technical report on the Olaroz project-NI 43-101 report prepared for Orocobre Ltd.: Milton, Queensland, Orocobre Ltd., 119 p.

Industrial Minerals, 2008a, Ringbolt enters Canadian potash: Industrial Minerals, no. 487, p. 23.

Industrial Minerals, 2008b, Salvador potash: Industrial Minerals, no. 495, p. 91.

Industrial Minerals, 2008c, Kouilou potash: Industrial Minerals, no. 489, p. 99.

Industrial Minerals, 2010, GrowMax potash gets $\$ 10 \mathrm{~m}$. boost: Industrial Minerals Web page, accessed June 21, 2010, at http://www.indmin.com/Article/2392711/GrowMax-potashgets-10m-boost.html.

Interfax America Inc., 2012, Potash production statistics in Belarus-Belaruskali launches 1st phase of Beryozovsky Mine: ReportLinker Web page, accessed November 25, 2012, at http://www.reportlinker-news.com/n043898003/ Belaruskali-launches-first-phase-of-Beryozovsky-mine. html. 
International Commission on Stratigraphy, 2010, International stratigraphic chart, accessed February 27, 2011, at http://www.stratigraphy.org/ics\%20chart/09_2010/ StratChart2010.pdf.

Jasinski, S.M., 2011a, Potash, in Mineral commodity summaries 2010: U.S. Geological Survey, p. 122-123. (Also available at http://minerals.usgs.gov/minerals/pubs/ commodity/potash/mcs-2011-potas.pdf.)

Jasinski, S.M., 2011b, Potash [advance release], in Metals and minerals: U.S. Geological Survey Minerals Yearbook 2009, p. 58.1-58.8, accessed August 10, 2011, at http://minerals. usgs.gov/minerals/pubs/commodity/potash/myb1-2009potas.pdf.

Jasinski, S.M., 2012, Potash, in Mineral Commodity Summaries 2012: U.S. Geological Survey p. 122-123, accessed March 5, 2012, at http://minerals.er.usgs.gov/ minerals/pubs/commodity/potash/mcs-2012-potas.pdf.

K+S Potash Canada, 2011, Saskatchewan's first new potash mine in nearly 40 years: $\mathrm{K}+\mathrm{S}$ Potash Canada Web page, accessed June 17, 2011, at http://www.ks-potashcanada. com/en/legacy/overview.html.

King, Mark, 2010, Amended inferred resource estimation of lithium and potassium at the Cauchari and Olaroz salars, Jujuy Province, Argentina: Halifax, Nova Scotia, Groundwater Insight, 109 p.

Kingston, D.R., Dishroon, C.P., and Williams, P.A., 1983, Global basin classification system: American Association of Petroleum Geologists Bulletin, v. 67, no. 12, p. 2175-2195.

Korin, S.S., 1992, Tektonicheskiye usloviya formirovaniya struktury kaliynykh mestorozhdeniy v Borislavo-Pokutskom pokrove [Tectonic conditions of potash deposit structure formation in the Borislav-Pokutsk Nappe]: Otechestvennaya Geologiya, v. 1992, no. 12, p. 20-26.

Kumar, V., and Bakliwal, P.C., 2005, Potash in India: Geological Survey of India Miscellaneous Publication 65, $131 \mathrm{p}$.

Kumar, Virendra, and Chandra, Ram, 2005, Geology and evolution of Nagaur-Ganganagar Basin with special reference to salt and potash mineralization: Geological Survey of India Special Publication 62, 151 p.

Lacus Minerals, 2010, Li3 Energy executes final agreement to acquire Puna Lithium assets in Argentina: Buenos Aires, Lacus Minerals Web page, accessed September 6, 2012, at http://www.lacusminerals.com/corporate.html.

Larrondo, P., Simon, A., and Etienne, M., 2011, Salar de Diablillos project, Salta Province, Argentina, NI 43-101 Technical Report on brine resource estimate: Santiago, Chile, AMEC International Ingeniería y Construción Limitada, 126 p.
Leeder, Mike, 1999, Sedimentology and sedimentary basinsFrom turbulence to tectonics: Oxford, Blackwell, 592 p.

Li3 Energy, 2011, Maricunga overview: Lima, Perú, Li3 Energy Web page, accessed June 13, 2011, at http://www. li3energy.com/projects/maricunga-overview/index.htm.

Lomas, S., 2008, NI 43-101 Technical report for a resource estimation on the Burr project and review of other permitted areas for Athabasca Potash Inc., Saskatchewan, Canada: Saskatoon, Saskatchewan, AMEC Americas Limited, variously paged.

MacPherson, Iain, 2009, Sintoukola Potash Project, Republic of Congo, 24th November 2009: West Perth, Western Australia, Elemental Minerals Ltd. Web page, accessed February 15, 2010, at http:/www.elementalminerals.com. au/index.php?option $=$ com_content $\&$ task $=$ view\&id=17\&Ite mid=93.

Magen, H., 2010a, Current world potash situation \& future outlook, AFA International Annual Fertilizers Forum \& Exhibition: Cairo, Egypt, International Potash Institute, 10 p., downloaded from International Potash Institute Web page, accessed August 25, 2011, at http://www.ipipotash. org/udocs/Current_World_Potash_Situation_and_Future Outlook_paper.pdf.

Magen, H., 2010b, Current world potash situation \& future outlook, AFA International Annual Fertilizers Forum \& Exhibition: Cairo, Egypt, International Potash Institute, presentation downloaded from International Potash Institute Web page, accessed August 25, 2011, at http://www. ipipotash.org/udocs/Current_World_Potash_Situation_and Future_Outlook.pdf.

Mann, P., Hempton, M.R., Bradley, D.C., and Burke, K., 1983, Development of pull-apart basins: Journal of Geology, v. 91 , no. 5 , p. 529-554.

Marifil Mines Ltd., 2011a, K-2: Marifil Mines Ltd. Web page, accessed March 11, 2011, at http://www.marifilmines.com/s/ K2.asp.

Marifil Mines Ltd., 2011b, K-2 Potash Project; joint venture with Saccharum Energy Corp.: Marifil Mines, 2 p., downloaded March 11, 2011, from http://www.marifilmines. com/i/pdf/K-2-Report.pdf.

Merle, O., 2011, A simple continental rift classification: Tectonophysics, v. 513, p. 88-95.

Mesa Exploration, 2011, Potash-Utah: Vancouver, B.C., Mesa Exploration Web page, accessed April 11, 2011, at http://www.mesaexploration.com/s/PotashUtah. asp?ReportID=352402.

Miall, A.D., 1984, Principles of Sedimentary Basin Analysis: New York, Springer-Verlag, 490 p. 
Middleton, M.F., 1989, A model for the formation of intracratonic sag basins: Geophysical Journal International, v. 99 , p. 665-676.

Mining Top News, 2009, High probability of potash-bearing beds underlying the Eyehill Creek property: Mining Top News Web page, accessed December 14, 2009, at http:// www.miningtopnews.com/high-probability-of-potashbearing-beds-underlying-the-eyehill-creek-property.html.

Molavi, M., Gebhardt, E., Halabura, S.P., and Shewfelt, D., 2010, Technical report update concerning subsurface mineral permit KP 360, Quill Lakes area, Saskatchewan, prepared for Karnalyte Resources Inc., Okotoks, AB: Saskatoon, Saskatchewan, North Rim Exploration Inc., $127 \mathrm{p}$. plus appendixes.

Moore, Garth, 2010, Global potash overview, March 16, 2010: Saskatoon, Saskatchewan, Potash Corporation of Saskatchewan Inc. presentation, accessed October 8, 2010, at http://www.potashcorp.com/media/2010_Mine_TourGarth_Moore.pdf.

Moore, G.W., Appleyard, Janelle, Danyluk, Terry, Nemeth, Balazs, Prugger, Arnfinn, and Roulston, Brian, 2008, National Instrument 43-101 technical report on Penobsquis \& Picadilly potash deposits, King's County, New Brunswick, Canada: Saskatoon, Saskatchewan, Potash Corporation of Saskatchewan Inc., 83 p.

Moore, Garth, Danyluk, T.K., Franklin, Bob, Prugger, Arnfinn, and Vander Most, Anastasia, 2010, National instrument 43-101 technical report on Rocanville potash deposit (KLSA-002) Saskatchewan, Canada: Saskatoon, Saskatchewan, Potash Corporation of Saskatchewan, Inc., $68 \mathrm{p}$.

Neuendorf, K.K.E., Mehl, Jr., J.P., and Jackson, J.A., 2005, Glossary of Geology, 5th edition: Alexandria, Virginia, American Geological Institute, 799 p. (Also available at http://www.agiweb.org/pubs/glossary/.)

New World Resource Corp., 2008, New World to acquire lithium brine project within the prolific Andean Altiplano: Vancouver, British Columbia, New World Resource Corp. Web page, accessed December 27, 2008, at http://www.newworldresource.com/s/NewsReleases. asp?ReportID $=317797 \& \_$Title $=$New-World-to-AcquireLithium-Brine-Project-within-the-Prolific-AndeanAltiplano.

NGEx Resources Inc., 2011, Bada potash: Vancouver, B.C., NGEx Resources Inc. Web page, accessed June 9, 2011, at http://www.ngexresources.com/s/BadaPotash.asp.
Northern Miner, 2009, MagIndustries gets the gas it needs to fertilize: Northern Miner Web page, accessed December 21, 2010, at http://www.northernminer.com/issues/ PrinterFriendly.asp?story_id $=\& \mathrm{id}=97952 \&$ RType $=\& \mathrm{PC}=\&$ is sue $=03262009$.

Orocobre, 2010, Olaroz lithium project: Orocobre Web page accessed January 3, 2010, at http://www.orocobre.com.au/ Projects_Olaroz.htm.

Orris, G.J., 2011, Closed-basin potash-bearing brines: U.S. Geological Survey Open-File Report 2011-1283, 11 p.

Ourchemical, 2011, Found in western Qaidam salt and brines: Ourchemical Web page, accessed August 16, 2011, at http:// www.ourchemical.com/catalogs_14/145398-73-8.html.

Pavlovic, P., and Fowler, J., 2004, Evaluation of the potential of Salar del Rincon brine deposit as a source of lithium, potash, boron and other mineral resources: Melbourne, Australia, Admiralty Resources NL and Argentina Diamonds Ltd., 33 p.

Peryt, T.M., Tomassi-Morawiec, H., Czapowski, G., Hryniv, S.P., Pueyo, J.J., Eastoe, C.J., and Vovnyuk, S., 2005, Polyhalite occurrence in the Werra (Zechstein, Upper Permian) peribaltic basin of Poland and Russia-Evaporite facies constraints: Carbonates and Evaporites, v. 20, no. 2, p. 182-194.

Pinheiro, J.C.F., 2008, Produção e comercialização de fertilizantes agrícolas no país - Títulos de Concessão de Pesquisa Mineral e Lavra de Fosfato e Potássio [Production and marketing of agricultural fertilizers in the countrySecurities Grant Mineral Research and Exploitation of Phosphate and Potassium]: Departamento Nacional de Produção Mineral, Presentation to Camara dos Deputados Comissão de Agricultura, Pecuária, Abastecimento e Desenvolvimento Rural, 15 July 2008, accessed November 28, 2008, at http://www2.camara.gov.br/atividade-legislativa/ comissoes/comissoes-permanentes/capadr/audiencias-2008/ rap150708joaocesar.pdf.

Potássio do Brasil, 2011, Potassio do Brasil intersects 39.94\% $\mathrm{KCl}$ at $843.08 \mathrm{~m}$ confirming the world class potash potential of the Amazon Basin-Brazil: Potássio do Brasil Web page, accessed December 9, 2011, at http://potassiodobrasil.com. br/uploads/files/press-releases/20110823_BPC-PressRelease19August2011.pdf.

Rauche, H., and van der Klauw, S.N.G.C., 2009, Updated reserve and resource estimate for MagMinerals Mengo permit area, Kouilou region, Republic of Congo; Technical report prepared for MagMinerals Inc.: Erfurt, Germany, ERCOSPLAN Ingenieurgesellschaft Geotechnik und Bergbau mbH, downloaded from MagIndustries Web page, accessed May 21, 2010, at http://www.magindustries. com/cmsdocs/Technical\%20Reports/08-016_NI-43-101_ Updated_Reserve-Report_June_2009_rev01.pdf. 
Rauche, H., and van der Klauw, S.N.G.C., 2011, Danakil potash deposit, Afar State, Ethiopia, G\&B PropertyPreliminary resource assessment study: Erfurt, Germany, ERCOSPLAN Ingenieurgesellschaft Geotechnik und Bergbau mbH, 103 p.

Ravnas, R., and Steel, R.J., 1998, Architecture of marine rift-basin successions: American Association of Petroleum Geologists Bulletin, v. 82, no. 1, p. 110-146.

Redstone Resources, 2011, Potassium-Aneba Project: Redstone Resources Web page, accessed January 3, 2011, at http://www.redstone.com.au/projects_aneba.html.

Ringbolt Ventures Ltd., 2008, Properties overview: Ringbolt Ventures Web page, accessed October, 2008, at http://www. ringboltventures.com/properties.php.

Ringbolt Ventures Ltd., 2011a, Holbrook Basin, Arizona: Vancouver, British Columbia, Ringbolt Ventures Ltd. Web page, accessed May 24, 2011, at http:/www. ringboltventures.com/properties_holbrook_basin.php.

Ringbolt Ventures Ltd., 2011b, Lisbon Valley, Utah (Paradox Basin)_ potash: Vancouver, British Columbia, Ringbolt Ventures Ltd. Web page, accessed May 24, 2011, at http:// www.ringboltventures.com/properties_paradox_basin.php.

Rodinia Lithium, 2011, Salar de Diablillos project: Toronto, Rodinia Lithium Web page, accessed March 11, 2011, at http://rodinialithium.com/projects/diabillos/.

Roth, H., 1972, Deformations in subhorizontal salt deposits of German Zechstein 1, Geology of saline deposits-Géologie des dépôts salins - Proceedings of the Hanover symposium organized by UNESCO and the Bundesanstalt für Bodenforschung and sponsored by the International Union of Geological Sciences, 15-21 May 1968: Paris, UNESCO, Earth Sciences 7, p. 225-233.

Safirova, E., 2012, The mineral industry of Uzbekistan-2010 [advance release]: U.S. Geological Survey 2010 Minerals Yearbook, p. 49.41-49.45.

Schulz, K.J., and Briskey, J.A., 2003, The Global Mineral Resource Assessment Project: U.S. Geological Survey Fact Sheet 053-03, accessed February 2, 2011, at http://pubs. usgs.gov/fs/fs053-03/.

Scotese, C.R., 2008, Shapefile library: Arlington, Tex., Paleomap Project, http://scotese.com.

Shuai, K., 1993, Characteristics of the potash deposits in western Yunnan, China, in Kakihana, H., Hardy, H.R., Jr., Hoshi, T., and Toyokura, K., eds., Seventh Symposium on Salt, Volume One: New York, Elsevier, p. 205-210.

Singer, D.A., 1993, Basic concepts in three-part quantitative assessments of undiscovered mineral resources: Nonrenewable Resources, v. 2, no. 2, p. 69-81.
Singer, D.A., and Menzie, W.D., 2010, Quantitative mineral resource assessments-An integrated approach: New York, Oxford University Press, 219 p.

Sirius Minerals, 2011a, North Yorkshire: London, UK, Sirius Minerals Web page, accessed July 3, 2011, at http://www. siriusminerals.com/index.php?option $=$ com_content\&view $=$ article $\&$ id $=3 \&$ Itemid $=40$.

Sirius Minerals, 2011b, North Dakota: Denver, Colo., Sirius Minerals Web page, accessed July 3, 2011, at http://www. siriusminerals.com/index.php?option $=$ com_content\&view $=$ article \&id=11\&Itemid $=41$.

Sirius Minerals, 2011c, Western Australia: Sydney, Australia, Sirius Minerals Web page, accessed April 30, 2011, at http:// www.siriusminerals.com/index.php?option=com_content\&v iew $=$ article $\& i d=12 \&$ Itemid $=64$.

Sirius Minerals, 2011d, Adavale: Sydney, Australia, Sirius Minerals Web page, accessed December 9, 2011, at http:// www.siriusminerals.com/adavale.

Sirocco Mining Inc., 2012, Salvador potash project: Sirocco Mining Inc. Web page, accessed March 25, 2012, at http:// www.siroccomining.com/s/SalvadorPotash.asp.

Sorentino, C.M.R., 2004, Report of an independent technical review and valuation of the Salar del Rincón asset and opinion on the market value of Admiralty Resources NL: Melbourne, Australia, Admiralty Resources, 15 p.

Spinetto, J.P., and Gonzalez, P., 2013, Vale Argentine potash project suspended indefinitely, Bloomberg: Bloomberg: New York, Bloomberg L.P. Web Page, accessed September 19, 2013, at http:/www.bloomberg.com/ news/2013-01-23/vale-argentine-potash-project-suspendedindefinitely.html.

Stirrett, T.A., and Gebhardt, E., 2011, Technical summary report for 2011 Encanto Potash Inc. potash resource assessment for Muskowekwan First Nations Home Reserve, Saskatchewan, Canada: North Rim Exploration Ltd., 85 p.

Transit Holdings Ltd., 2011, Potash-Paradox Basin potash project: West Perth, WA, Transit Holdings Ltd. Web page, accessed April 4, 2011, at http://www.transitholdings.com. $\mathrm{au} /$ contact.html.

United Nations, 2011, Composition of macro geographical (continental) regions, geographical sub-regions, and selected economic and other groupings: United Nations Web page, accessed September 10, 2011, at http://unstats. un.org/unsd/methods/m49/m49regin.htm.

U.S. Department of State, 2009, Small-scale digital international land boundaries (SSIB) — Lines, edition 10, and polygons, beta edition 1, in Boundaries and sovereignty encyclopedia (B.A.S.E.): U.S. Department of State, Office of the Geographer and Global Issues. 
Wang, M., Liu, C., Jiao, P., and Yang, Z., 2005, Minerogenic theory of the superlarge Lop Nur potash deposit, Xinjiang, China: Acta Geologica Sinica, v. 79, no. 1, p. 53-65.

Wang, Q., 2010, Sino-Agri potash project in Laos, presentation at IFA Crossroads Asia-Pacific 2010 Conference, Hanoi, Vietnam, 8-10 November 2010: International Fertilizer Association Web page, accessed June 17, 2011, at http:// www.fertilizer.org/ifacontent/.../2010_crossroads_wang_ slides.pdf.

Warren, J.K., 1991, Chapter 2. Sulfate dominated sea-marginal and platform evaporative settings - Sabkhas and salinas, mudflats and salterns, in Melvin, J.L., ed., Evaporites, petroleum and mineral resources: New York, Elsevier, p. 69-187.

Warren, J.K., 2010, Evaporites through time-Tectonic, climatic and eustatic controls in marine and nonmarine deposits Earth-Science Reviews, v. 98, no. 3-4, p. 217-268.

Western Potash, 2008, Milestone Project: Western Potash Web page, accessed December 14, 2008, at http://www. westernpotash.com/projects/milestone.

Western Potash, 2010, Western Potash Corp. updates measured and indicated potash resource to 174 million tonnes: Western Potash Corp Web page, accessed July 5, 2010, at http://www.westernpotash.com/.
Western Potash, 2011a, Russell, Manitoba: Vancouver, British Columbia, Western Potash Web page, accessed March 22, 2011, at http:/www.westernpotash.com/projects/russell.

Western Potash, 2011b, Milestone, Saskatchewan: Vancouver, British Columbia, Western Potash Web page, accessed March 22, 2011, at http://www.westernpotash.com/projects/ milestone.

Yuan, J., Cai, K., Tao, W., Wang, Q., Shuai, K., Peng, S., Li, R., Wei, D., and Zhang, Y., 1996, Salt deposits of China, in The Editorial Committee of The Mineral Deposits of China, ed., Mineral deposits of China, Volume 4: Beijing, China, Geological Publishing House, p. 168-234.

Zharkov, M.A., 1981, History of Paleozoic salt accumulation: New York, Springer-Verlag, 308 p.

Zharkov, M.A., 1984, Paleozoic salt bearing formations of the world: New York, Springer-Verlag, 427 p.

Zheng, M., and Liu, X., 2009, Hydrochemistry of salt lakes of the Qinghai-Tibet Plateau, China: Aquatic Geochemistry, v. 15 , p. $293-320$. 
This page intentionally left blank. 
Appendixes A-F 


\title{
Appendix A. Summary Descriptive Model of Stratabound Potash-Bearing Salt Deposits
}

\author{
By Mark D. Cocker ${ }^{1}$ and Greta J. Orris ${ }^{1}$
}

\section{Introduction}

Stratabound potash-bearing salt is associated with thick sections of evaporitic salt (halite) that form laterally continuous strata in marine evaporite basins. Deposits are extremely soluble and thus easily altered or destroyed over geologic time. Stratabound potash deposits range in size from several tens of millions to more than 30 billion metric tons of potassium oxide $\left(\mathrm{K}_{2} \mathrm{O}\right)$. Most of the world's potash resources are associated with this deposit type.

\section{Representative Deposits}

Examples of stratabound potash-bearing salt deposits include those in the Givetian (Middle Devonian) Elk Point Basin in Canada, the Frasnian and Famennian (Upper Devonian) Pripyat Basin in Belarus, and the Lopingian (upper Permian) Solikamsk Basin in Russia (fig. A1). Some larger basins, such as the Lopingian Zechstein Basin in Europe and the Central Asia Salt Basin (fig. A1), contain potash-bearing salt in both stratabound and halokinetic (appendix B) forms.

\section{Brief Description}

\section{Synonyms}

Synonyms for this type of deposit include potash deposits, potash-bearing salt deposits, bedded potash, and marine potash.

\section{Principal Commodities and Byproducts}

The principal products of potash mining are potassium oxide $\left(\mathrm{K}_{2} \mathrm{O}\right)$, which is referred to as muriate of potash (MOP), and potassium sulfate $\left(\mathrm{K}_{2} \mathrm{SO}_{4}\right)$, which is referred to as sulfate of potash (SOP). Where carnallite $\left(\mathrm{KMgCl}_{3} \cdot 6 \mathrm{H}_{2} \mathrm{O}\right)$ constitutes a major portion of a deposit, magnesium may be recovered. The main byproduct commodity is halite or rock salt.

\section{Relative Importance of the Deposit Type}

Stratabound potash-bearing salt deposits may contain billions to trillions of tons of mineralized rock and are amenable to relatively low cost, bulk underground mining methods. Approximately 75 percent of the world's potash production is from stratabound potash-bearing salt deposits, and more than 25 percent of that production is from the Middle Devonian Prairie Evaporite Formation of the Elk Point Basin in Saskatchewan, Canada.

\section{Global Distribution}

The largest and economically most important deposits of potash are found in North America, Europe, and Asia. Newly explored deposits in Africa and South America are increasingly important.

\section{Associated/Related Deposit Types}

Stratabound potash-bearing salt deposits are associated with stratabound and bedded gypsum, anhydrite, halite, and sulfur deposits (Long, 1992). Halokinetic potash-bearing salt deposits (see appendix B, this report) originally formed in the same manner as stratabound deposits but deformation of salt resulted in grade and tonnage differences between these two end member deposit types. Stratabound and halokinetic potash-bearing salt may occur concurrently in some larger basins.

\section{Descriptive and Genetic Synopsis}

Potash-bearing salt is a chemically deposited sedimentary rock made up of fine- to coarse-grained, potassium- and magnesium-chloride and sulfate minerals intergrown with halite. Beds of laterally continuous stratabound potash-bearing salt occur within thick sections of halite-dominant evaporite deposits. Potash-bearing strata range from centimeters to meters in thickness, and potash-bearing intervals may consist of one bed or numerous thin layers. 
Appendix A 53

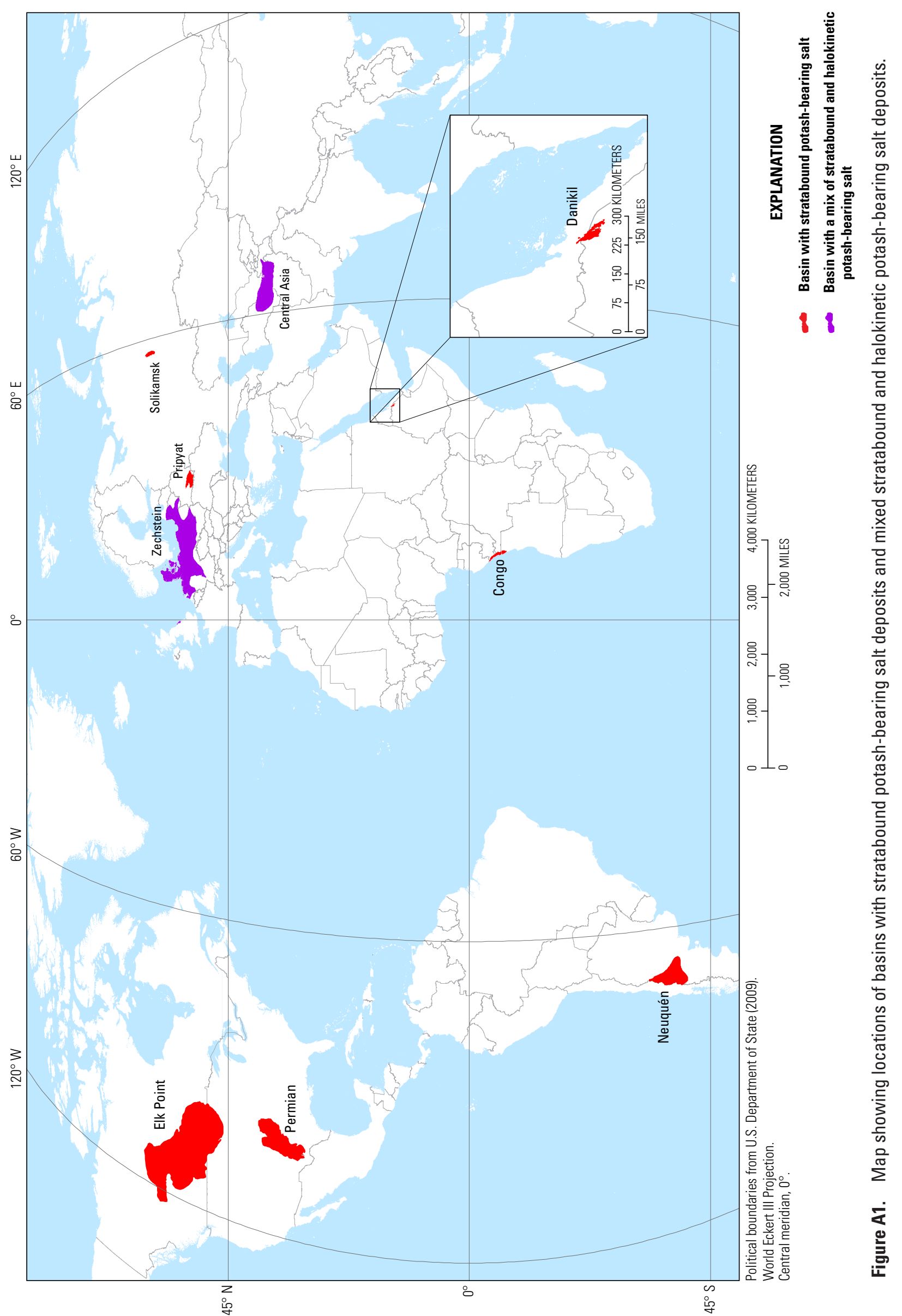


These deposits are commonly attributed to evaporation of large volumes of seawater in hydrographically restricted or isolated basins under hyperarid climatic conditions (Warren, 2006, 2010; Kendall, 2010). Progressive evaporation of saline water (usually seawater) and salt precipitation contribute to increasingly hypersaline conditions, formation of bitterns, and eventual deposition of potassium- and magnesium-bearing minerals. Multiple episodes of saline water inflow result in cyclic deposition of potash minerals and yield deposits that are many tens of meters thick.

\section{Permissive Tract Delineation}

The fundamental geologic feature for delineation of tracts permissive for stratabound potash-bearing salt is an evaporitebearing sedimentary basin that contains halite-dominated areas and evidence that evaporation reached the bittern stage. Evidence of potash mineralization includes reports of the presence of sylvite, carnallite, polyhalite, or other potassium saline minerals, or indirect evidence from downhole geophysical surveys.

Permissive tracts are outlined by selecting basins with known evaporites, restricting tract boundaries to areas likely underlain by salt at depths of 3 kilometers or less, and if possible, using drill hole or other information to limit tracts to areas underlain by potash-bearing salt. Halite-rich layers are preferably many tens to hundreds of meters thick and (or) areally extensive.

\section{Regional Geologic Attributes}

\section{Tectonic Setting of Basin}

Stratabound potash-bearing salt is found in sedimentary basins that formed in regions of arid climate. Tectonic plate interactions that formed basins located between $15^{\circ}$ and $45^{\circ}$ north and south of the equator were the likely places for stratabound potash-bearing salt deposition. Deposits have been described in continental and oceanic rift basins, foreland basins, intracontinental sag basins, and in transform basins that are products of the breakup (or failed breakup) of continents, convergence or collision of continental plates, or intraplate thinning and weakening (Warren, 2010). Basin type is less critical than climatic conditions at the time of deposition. Hot, hyperarid climatic conditions are necessary to form brines from saline waters and deposit evaporites. These conditions may result from global scale atmospheric wind circulation patterns (Warren, 2010). Many of the world's deserts are near latitudes of $30^{\circ} \mathrm{N}$ and $30^{\circ} \mathrm{S}$, which correspond to the boundary between atmospheric circulation cells.

\section{Depositional Systems}

In an evaporite basin, near-shore, shallow clastic facies rocks grade to carbonate-, then sulfate-, then halide-rich rocks towards the central part of a basin or parts more distal from the point of seawater influx. Central parts of an evaporite basin may have facies representing shallow water to deeper water (Warren, 2006; Kendall, 2010; Schmalz, 1969). The resulting stratigraphic sequence begins with minor clastic red beds, followed by carbonate rocks, anhydrite or gypsum, salt, and ends with potash-bearing salt. Multiple episodes of evaporite mineral precipitation may be recorded in cyclic sequences of rock layers, with individual cyclic units from a few centimeters to hundreds of meters thick.

\section{Age Range and Age-Related Features}

Potash-bearing salt deposits are found in basins that are Neoproterozoic in age or younger (Goncharenko, 2006; Kovalevych and others, 2006; Warren, 2006, 2008; Zharkov, 1984, 2005). Half of the world's known potash-containing basins are Middle and Late Devonian, Permian, or Paleogene-Neogene in age (Goncharenko, 2006).

Differences in deposit mineralogy likely reflect temporal changes in global seawater chemistry. During the Phanerozic, marine brine chemistry appears to have oscillated between Na-K$\mathrm{Mg}-\mathrm{Ca}-\mathrm{Cl}$ and $\mathrm{Na}-\mathrm{K}-\mathrm{Mg}-\mathrm{Cl}-\mathrm{SO}_{4}$ types (Hardie, 1990, 1996; Holland and others, 1996; Horita and others, 2002; Kovalevych and others, 1998; Ries, 2010; Warren, 2006). Magnesium sulfatepoor deposits dominated by sylvite and carnallite are derived from the $\mathrm{Na}-\mathrm{K}-\mathrm{Mg}-\mathrm{Ca}-\mathrm{Cl}$ brines. Magnesium-rich sulfate type deposits, with variable amounts of $\mathrm{K}$ - and Mg-sulfate minerals, may form from Na-K-Mg-Cl-SO ${ }_{4}$ brines. Local environmental conditions may be significant factors in basin brine geochemistry.

\section{Local Geologic Attributes and Deposit Characteristics}

\section{Host Rocks}

Host rocks are evaporitic sedimentary rocks, such as rock salt, sylvinite, carnallitite, kainitite, hartsalz, anhydrite, and gypsum. The mineralized rock strata consist of potash salt minerals, including chlorides, sulfates, and halite, in evaporite sequences.

\section{Deposit Characteristics}

\section{Deposit Form and Dimensions}

Stratabound potash-bearing salt deposits are composed of one or more layers or beds of potash-bearing salt. The beds or layers or groups of layers are commonly laterally continuous across large areas of a basin. Individual potash beds or layers range in thickness from less than a meter to several tens of meters, to almost a hundred meters (rare). A sequence of potash-bearing salt beds may range from tens of meters to a few hundred meters thick. The areal extent of potash mineralization is ultimately limited by the basin size at time of deposition. Typical volumes of stratabound potash-bearing salt can be hundreds to thousands of cubic kilometers. 
Mineralogy

Ore Mineralogy

Primary ore minerals include sylvite, carnallite, kainite, polyhalite, and langbeinite (table A1). These minerals are most commonly found as intergrowths with halite.

\section{Ore Assemblages}

The dominant ore assemblages contain sylvite and halite with minor ( $<6$ weight percent) carnallite or carnallite plus halite with negligible amounts of sylvite. Some deposits may contain ore assemblages of kainite, langbeinite, polyhalite, kieserite and (or) bischofite mixed with halite and gypsum or anhydrite.
Gangue Mineralogy

Gangue minerals include halite, clay minerals, dolomite, anhydrite, gypsum, bischofite, epsomite, tachyhydrite, leonite, blödite, hexahydrite, vanthoffite, löweite, aphthitalite, picromerite, and borate minerals (table A1). Sonnenfeld (1991) noted the presence of halloysites, kaolinite, iron-chlorite, magnesium-chlorites, montmorillonite, palygorskite, illite, sepiolite, and muscovite in evaporite basins.

Primary mineral zoning may consist of an outer or stratigraphically lower zone dominated by sulfates such as anhydrite or gypsum, changing to a halite-dominated zone, and culminating with an inner or upper zone containing halite plus potassium chloride or potassium sulfate minerals. Under certain conditions at the end of an evaporation sequence, some other bittern minerals such as tachyhydrite or bischofite may also be present and preserved. These minerals are highly soluble and are commonly no longer present in most of these deposits.

Table A1. Ore minerals and common accessory and gangue minerals in stratabound potash-bearing salt deposits.

[Composition formulas from Back and Mandarino (2008)]

\begin{tabular}{|c|c|c|c|}
\hline Ore minerals & Composition & Other minerals & Composition \\
\hline Carnallite & $\mathrm{KMgCl}_{3} \cdot 6 \mathrm{H}_{2} \mathrm{O}$ & Aphthitalite & $(\mathrm{K}, \mathrm{Na})_{3} \mathrm{Na}\left(\mathrm{SO}_{4}\right)_{2}$ \\
\hline Kainite & $\mathrm{MgSO}_{4} \cdot \mathrm{KCl} \cdot 3 \mathrm{H}_{2} \mathrm{O}$ & Anhydrite & $\mathrm{CaSO}_{4}$ \\
\hline Langbeinite & $\mathrm{K}_{2} \mathrm{Mg}_{2}\left(\mathrm{SO}_{4}\right)_{3}$ & Bischofite & $\mathrm{MgCl} \cdot 6 \mathrm{H}_{2} \mathrm{O}$ \\
\hline Polyhalite & $\mathrm{K}_{2} \mathrm{Ca}_{2} \mathrm{Mg}\left(\mathrm{SO}_{4}\right)_{4} \cdot 2 \mathrm{H}_{2} \mathrm{O}$ & Blödite & $\mathrm{Na}_{2} \mathrm{Mg}\left(\mathrm{SO}_{4}\right)_{2} \bullet 4 \mathrm{H}_{2} \mathrm{O}$ \\
\hline \multirow[t]{20}{*}{ Sylvite } & $\mathrm{KCl}$ & Boracite & $\mathrm{Mg}_{7} \mathrm{~B}_{7} \mathrm{O}_{13} \mathrm{Cl}$ \\
\hline & & Dolomite & $\mathrm{CaMg}\left(\mathrm{CO}_{3}\right)_{2}$ \\
\hline & & Epsomite & $\mathrm{MgSO}_{4} \cdot 7 \mathrm{H}_{2} \mathrm{O}$ \\
\hline & & Gypsum & $\mathrm{CaSO}_{4} \cdot 2 \mathrm{H}_{2} \mathrm{O}$ \\
\hline & & Halloysite & $\mathrm{Al}_{2} \mathrm{Si}_{2} \mathrm{O}_{5}(\mathrm{OH})_{4}$ \\
\hline & & Halite & $\mathrm{NaCl}$ \\
\hline & & Hexahydrite & $\mathrm{MgSO}_{4} \cdot 6 \mathrm{H}_{2} \mathrm{O}$ \\
\hline & & Kaolinite & $\mathrm{Al}_{2} \mathrm{Si}_{2} \mathrm{O}_{5}(\mathrm{OH})_{4}$ \\
\hline & & Kieserite & $\mathrm{MgSO}_{4} \cdot \mathrm{H}_{2} \mathrm{O}$ \\
\hline & & Kurnakovite & $\mathrm{K}_{2} \mathrm{Mg}\left(\mathrm{SO}_{4}\right)_{2} \cdot 4 \mathrm{H}_{2} \mathrm{O}$ \\
\hline & & Leonite & $\mathrm{Na}_{12} \mathrm{Mg}_{7}\left(\mathrm{SO}_{4}\right)_{13} \cdot 15 \mathrm{H}_{2} \mathrm{O}$ \\
\hline & & Löweite & $(\mathrm{Na}, \mathrm{Ca})_{0.3}(\mathrm{Al}, \mathrm{Mg})_{2} \mathrm{Si}_{4} \mathrm{O}_{10}(\mathrm{OH})_{2} \cdot \mathrm{nH}_{2} \mathrm{O}$ \\
\hline & & Lüneburgite & $\mathrm{Mg}_{3} \mathrm{~B}_{2}\left(\mathrm{PO}_{4}\right)_{2}(\mathrm{OH})_{6} \cdot 6 \mathrm{H}_{2} \mathrm{O}$ \\
\hline & & Montmorillonite & $(\mathrm{Mg}, \mathrm{Al})_{2} \mathrm{Si}_{4} \mathrm{O}_{10}(\mathrm{OH}) \cdot 4 \mathrm{H}_{2} \mathrm{O}$ \\
\hline & & Palygorskite & $\mathrm{K}_{2} \mathrm{Mg}\left(\mathrm{SO}_{4}\right)_{2} \cdot 6 \mathrm{H}_{2} \mathrm{O}$ \\
\hline & & Picromerite & $\mathrm{Mg}_{4} \mathrm{Si}_{6} \mathrm{O}_{15}(\mathrm{OH})_{2} \cdot 6 \mathrm{H}_{2} \mathrm{O}$ \\
\hline & & Sepiolite & $\mathrm{CaMgCl}_{6} \cdot 12 \mathrm{H}_{2} \mathrm{O}$ \\
\hline & & Tachyhydrite & $\mathrm{Na}_{6} \mathrm{Mg}\left(\mathrm{SO}_{4}\right)_{4}$ \\
\hline & & Vanthoffite & $\mathrm{Na}_{6} \mathrm{Mg}\left(\mathrm{SO}_{4}\right)_{4}$ \\
\hline & & Volkovskite & $\mathrm{KCa}_{4} \mathrm{~B}_{22} \mathrm{O}_{32}(\mathrm{OH}) 10 \mathrm{Cl} \bullet 4 \mathrm{H}_{2} \mathrm{O}$ \\
\hline
\end{tabular}




\section{Effects of Alteration}

Potash-bearing salt is highly soluble and susceptible to alteration, recrystallization, and dissolution by surface water, less saline brine, and groundwater (Warren, 2010). Groundwater dissolution can modify the mineralogy, layering, grain size, or porosity, or it can totally destroy a deposit. Increased pressure and temperature related to burial metamorphism can also lead to recrystallization and destruction of primary textures and changes in grain size.

\section{Exploration Guides}

\section{Geochemical Signature(s)}

In many primary deposits, brines in boreholes may be anomalous in potassium, sodium, magnesium, bromine, chlorine, and sulfur (Rogers, 2011). Exceptionally saline wells and saline spring water are indicative of an evaporite sequence, and have historically led to discoveries of concealed salt and potash deposits.

Bromine content of halite increases as the salinity of the brine increases; bromine profiles show increasing upwards trends in unaltered evaporite cycles. Residual brines at this stage may contain hundreds of parts per million (ppm) bromine, and on the order of a thousand ppm or more bromine during precipitation of potash minerals, although reported values are typically much lower due to dilution and dissolution, diagenesis, and brine fluctuations (Webb and Stewart, 2011).

\section{Geophysical Signature(s)}

\section{Radiometric signatures}

High gamma radiation signatures from the natural isotope potassium-40 $\left(\mathrm{K}^{40}\right)$ are used to map potassium content of salt in downhole geophysical surveys (Garrett, 1996).

\section{Seismic signatures}

Reflection seismic methods are used to delineate salt structures and layers (Fox, 1987; Simeonova and Iasky, 2005).

\section{Other Exploration Guides}

Except for drilling confirmation of potash, there are few sure indications of the presence of potash-bearing salt. Thick sections of halite, usually greater than $100 \mathrm{~m}$, are believed to be necessary prior to potash deposition (Harben and Kužvart, 1996), and this could be used in conjunction with other data to identify or rank the potash potential of basins with little exploration history.

\section{Typical Grade and Tonnage}

Average reported potash grades in explored deposits of this type may range from 5.3 percent to 38 percent $\mathrm{K}_{2} \mathrm{O}$ (Kumar and Bakliwal, 2005; de Ruiter, 1979). Most reported grades in operating mines range from 11 to 25 percent $\mathrm{K}_{2} \mathrm{O}$. In general, the lowest average grade that is currently being mined is in the range of $8-10$ percent $\mathrm{K}_{2} \mathrm{O}$, with the lowest associated cutoff grade below 4 percent $\mathrm{K}_{2} \mathrm{O}$.

The minimum thickness of a potash layer that is being mined is about $1 \mathrm{~m}$. In Saskatchewan, minimal mining thicknesses range from 2.44 to $3.35 \mathrm{~m}$ because of the mining equipment used and the thickness of the highest grade ore in different mines (Moore and others, 2010a,b,c,d, 2011).

The reported range of tonnages for potash deposits ranges from a few tens of millions to 30 billion metric tons (British Sulphur Corporation Limited, 1984; Hardy and others, 2009). The reported tonnages since 2000 for greenfield potash projects that reported NI 43-101-compatible reserves and resources largely exceed 500 million metric tons, and commonly, 1 billion metric tons, of potash ore (Rauche and van der Klauw, 2009, 2012; South Boulder Mines, 2012; BHP Billiton, 2010; Western Potash, 2010).

\section{References}

Back, Malcolm, and Mandarino, J.A., 2008, Fleischers glossary of mineral species 2008: Mineralogical Record, Inc., $346 \mathrm{p}$.

BHP Billiton, 2010, BHP Billiton announces mineral resource estimate for its Jansen potash project: BHP Billiton news release, June 7, 2010, 2 p., accessed June 26, 2010, at http://www.bhpbilliton.com/bb/investorsMedia/news/2010/ bhpBillitonAnnouncesMineralResourceEstimateForItsJanse nPotash-Project.jsp.

British Sulphur Corporation Limited, 1984, World survey of potash resources (4th ed.): London, British Sulphur Corporation Limited, 145 p.

de Ruiter, P.A.C., 1979, The Gabon and Congo Basins salt deposits: Economic Geology, v. 74, no. 2, p. 419-431.

Fox, James, 1987, Seismic interpretation in salt-controlled basins: The Leading Edge, v. 6, no. 3, p. 11-18.

Garrett, D.E., 1996, Potash-Deposits, processing, properties and uses: New York, Chapman \& Hall, 734 p.

Goncharenko, O.P., 2006, Potassic salts in Phanerozoic evaporite basins and specific features of salt deposition at the final stages of halogenesis: Lithology and Mineral Resources, v. 41, no. 4, p. 378-388. 
Harben, P.W., and Kužvart, M., 1996, Industrial minerals-A global geology: London, Industrial Minerals Information Ltd., 462 p.

Hardie, L.A., 1990, The roles of rifting and hydrothermal $\mathrm{CaCl}_{2}$ brines in the origin of potash evaporites-An hypothesis: American Journal of Science, v. 290, no. 1, p. 43-106.

Hardie, L.A., 1996, Secular variation in seawater chemistryAn explanation for the coupled secular variation in the mineralogies of marine limestones and potash evaporites over the past 600 m.y.: Geology, v. 24, p. 279-283.

Hardy, M., Halabura, S.P., and Shewfelt, D., 2009, Technical Report-2009 potash resource assessment for Subsurface Mineral Permit KP 289, Saskatchewan: Agapito Associates, Inc., North Rim Exploration Ltd., 163 p.

Holland, H.D., Horita, Juske, and Seyfried, W.E., Jr., 1996, On the secular variation in the composition of marine potash evaporates: Geology, v. 24, no. 11, p. 993-996.

Horita, Juske, Zimmerman, Heide, and Holland, H.D., 2002, Chemical evolution of seawater during the PhanerozoicImplications from the record of marine evaporites: Geochimica et Cosmochimica Acta, v. 66, no. 21, p. 3733-3756.

Kendall, A.C., 2010, Marine evaporites, in James, N.P., and Dalrymple, R.W., eds., Facies models 4: Geological Association of Canada, GEOtext 6, p. 505-540.

Kovalevych, V.M., Peryt, T.M., and Petrychenko, O.Y., 1998, Secular variation in seawater chemistry during the Phanerozoic as indicated by brine inclusions in halite: Journal of Geology, v. 106, p. 695-712.

Kovalevych, V.M., Marshall, T., Peryt, T.M., Petrychenko, O.Y., and Zhukova, S.A., 2006, Chemical composition of seawater in Neoproterozoic-Results of fluid inclusion study of halite from Salt Range (Pakistan) and Amadeus Basin (Australia): Precambrian Research, v. 144, p. 39-51.

Kumar, V., and Bakliwal, P.C., 2005, Potash in India: Geological Survey of India Miscellaneous Publication 65, $131 \mathrm{p}$.

Long, K.R., 1992, Descriptive model of stratabound sulfur and contained-sulfur model of stratabound sulfur: U.S. Geological Survey Open-File Report 92-0705, 8 p.

Moore, G., Danyluk, T.K., Franklin, B., Prugger, A., and Vander Most, A., 2010a, National Instrument 43-101 technical report on Allan potash deposit (KL-112R), Saskatchewan, Canada: Saskatoon, Sask., Potash Corporation of Saskatchewan Inc., 62 p.
Moore, G., Danyluk, T.K., Franklin, B., Prugger, A., and Vander Most, A., 2010b, National Instrument 43-101 technical report on Cory potash deposit (KL-103R), Saskatchewan, Canada: Saskatoon, Sask., Potash Corporation of Saskatchewan Inc., 63 p.

Moore, G., Danyluk, T.K., Franklin, B., Prugger, A., and Vander Most, A., 2010c, National Instrument 43-101 technical report on Lanigan potash deposit (KLSA-001), Saskatchewan, Canada: Saskatoon, Sask., Potash Corporation of Saskatchewan Inc., 65 p.

Moore, G., Danyluk, T.K., Franklin, B., Prugger, A., and Vander Most, A., 2010d, National Instrument 43-101 technical report on Rocanville potash deposit (KLSA002), Saskatchewan, Canada: Saskatoon, Sask., Potash Corporation of Saskatchewan Inc., 68 p.

Moore, Garth, Danyluk, T.K., Franklin, Bob, Prugger, Arnfinn, and Vander Most, Anastasia, 2011, National Instrument 43-101 technical report on Rocanville potash deposit (KLSA-002) Saskatchewan, Canada: Saskatoon, Sask. Potash Corporation of Saskatchewan, Inc., 68 p.

Rauche, Henry, and van der Klauw, S.N.G.C., 2009, Updated reserve and resource estimate for MagMinerals Kouilou potash project, Republic of Congo: Technical report prepared for MagMinerals Inc., 209 p., accessed August 15, 2011, at http://www.magindustries.com/cmsdocs/ Technical\%20Reports/08-016_NI-43-101_Updated Reserve-Report_June_2009_rev01.pdf.

Rauche, Henry, and Van der Klauw, S.N.G.C., 2012, Preliminary economic assessment, sylvinite mining in the Danakhil potash deposit, Afar State, EthiopiaPreliminary economic assessment study: Erfurt, Germany, ERCOPSPLAN Ingenieurgesellschaft, 131 p. plus appendixes.

Ries, J.B., 2010, Review-Geological and experimental evidence for secular variation in seawater $\mathrm{Mg} / \mathrm{Ca}$ (calcitearagonite seas) and its effect on marine biological calcification: Biogeosciences, v. 7, p. 2795-2849.

Rogers, M.C., 2011, Saskatchewan descriptive mineral deposit models: Saskatchewan Ministry of Energy and Resources Open File Report 2011-57, 112 p.

Schmalz, R.F., 1969, Deep-water evaporite deposition-A genetic model: American Association of Petroleum Geologists Bulletin, v. 53, no. 4, p. 798-823.

Simeonova, A.P., and Iasky, R.P., 2005, Seismic mapping, salt deformation, and hydrocarbon potential of the central western Officer Basin, Western Australia: Western Australia Geological Survey Report 98, 49 p. plus appendixes. 
Sonnenfeld, P., 1991, Evaporite basin analysis, in Force, E.R., Eidel, J.J., and Maynard, J.B., Sedimentary and diagenetic mineral deposits - A basin analysis approach to exploration: Reviews in Economic Geology Volume 5, p. 159-169.

South Boulder Mines, 2012, Colluli potash project, Web site accessed April 17, 2012 at http://www.southbouldermines. com.au/projects/colluli-potash-project/.

U.S. Department of State, 2009, Small-scale digital international land boundaries (SSIB) — Lines, edition 10, and polygons, beta edition 1, in Boundaries and Sovereignty Encyclopedia (B.A.S.E.): U.S. Department of State, Office of the Geographer and Global Issues.

Warren, J.K., 2006, Evaporites-Sediments, resources and hydrocarbons: Berlin, Springer-Verlag, 1035 p.

Warren, J.K., 2008, Salt as sediment in the Central European Basin system as seen from a deep time perspective, in Littke, Ralf, Bayer, Ulf, and Gajewski, Dirk, eds., Dynamics of complex intracontinental basins: Berlin, Springer-Verlag, p. 249-276.

Warren, J.K., 2010, Evaporites through time-Tectonic, climatic, and eustatic controls in marine and nonmarine deposits: Earth-Science Reviews, v. 98, issues 3-4, February 2010, p. 217-268.
Webb, T.C., and Stewart, H.J., 2011, Bromine as an indicator of potash mineralization in Carboniferous marine evaporites, Sackville Subbasin, southeastern New Brunswick: New Brunswick Department of Natural Resources, Lands, Minerals and Petroleum Division Mineral Resource Report 2011-1, 40 p.

Western Potash, 2010, Western Potash Corp. updates measured and indicated potash resource to 174 million tonnes: Western Potash Corp Web page accessed July 5, 2010 at http://www.westernpotash.com/.

Zharkov, M.A., 1984, Paleozoic salt bearing formations of the world: New York, Springer-Verlag, 427 p.

Zharkov, M.A., 2005, Evolyutsiya evaporitov v dokembrii v svyazi s preobrazovaniyami biosfery i khimicheskogo sostava mirovogo okeana; Stat'ya 1, Evapority arkheya i rannego proterozoya [Evolution of Precambrian evaporites, transformation of biosphere and the world oceans' chemical composition-Paper 1, Archean and Paleoproterozoic evaporites]: Stratigrafiya, Geologicheskaya Korrelyatsiya, v. 13, no. 2, p. 19-29. 


\title{
Appendix B. Summary Descriptive Model of Halokinetic Potash-Bearing Salt Deposits
}

\author{
By Mark D. Cocker ${ }^{1}$ and Greta J. Orris ${ }^{1}$
}

\section{Introduction}

Halokinetic potash-bearing salt occurs in salt structures developed from stratabound potash-bearing salt deposits where differential loading by thick overlying sediments initiated and drove upward movement of low density potashbearing salt. The original stratabound salt beds are disrupted during halokinesis, resulting in complexly deformed lenses and beds of potash-bearing salt. Potash deposits within salt structures range in size from 1 million to more than 1,000 million metric tons. Most mined halokinetic potash deposits are from 50 million to several hundred million metric tons in size.

\section{Representative Deposits}

Some of the best known halokinetic potash-bearing salt deposits occur in the evaporites of the Lopingian (upper Permian) Zechstein Basin of Germany, Poland, The Netherlands, and Denmark; the Cisuralian (lower Permian) Pricaspian Basin of Kazakhstan and Russia; the Middle Pennsylvanian of the Paradox Basin in the United States; and the Miocene Carpathian Basin of Romania and Ukraine (fig. B1). Some larger basins, such as the Zechstein Basin (fig. B1) and the Central Asia Salt Basin (fig. B1) contain potash-bearing salt in both halokinetic and stratabound (appendix A) forms.

\section{Brief Description}

\section{Synonyms}

Synonyms for this type of deposit include potash deposits, potash-bearing salt deposits, diapiric potash, marine potash, and halokinetic potash-bearing salt deposits.

\section{Principal Commodities and Byproducts}

The principal products of potash mining are potassium oxide $\left(\mathrm{K}_{2} \mathrm{O}\right)$, which is referred to as muriate of potash (MOP), and potassium sulfate $\left(\mathrm{K}_{2} \mathrm{SO}_{4}\right)$, which is referred to as sulfate of potash (SOP). Where carnallite $\left(\mathrm{KMgCl}_{3} \cdot 6 \mathrm{H}_{2} \mathrm{O}\right)$ constitutes a major portion of a deposit, magnesium may be recovered. The main byproduct commodity is halite or salt.

\section{Relative Importance of the Deposit Type}

An estimated 10-15 percent of the world's potash production is from halokinetic potash-bearing salt deposits.

\section{Global Distribution}

The largest known deposits are found in Europe and Central Asia.

\section{Associated/Related Deposit Types}

Some salt structures may contain associated gypsum, sulfur, iodine, bromine, or borate deposits (Long, 1992; Raup, 1991). Salt structures and associated fault-related features commonly form hydrocarbon traps (Long, 1992; Kyle and Posey, 1991). Because stratabound potash-bearing salt deposits have not suffered the deformation characteristic of halokinetic potash-bearing salt deposits, there are important differences in grades and tonnages between these two end member deposit types. Stratabound and halokinetic potash-bearing salt may both occur in some larger basins.

\section{Descriptive and Genetic Synopsis}

Halokinetic potash-bearing salt deposits are the layers or beds of stratabound potash-bearing salt deposits that have moved by plastic flow into a salt structure along with the enclosing sedimentary rock, most of which is salt. The internal structure of the salt layers, and hence the potash-bearing salt layers, can be simple to complex, and the original continuity and thickness of the potash-rich layers may be altered considerably by the internal deformation.

Structural deformation of low density salt may be related to differential loading or unloading of the sedimentary sequence and local or regional tectonic activity. Halokinetic salt structures are generally developed in tectonically active salt basins such as rift or foreland basins. 

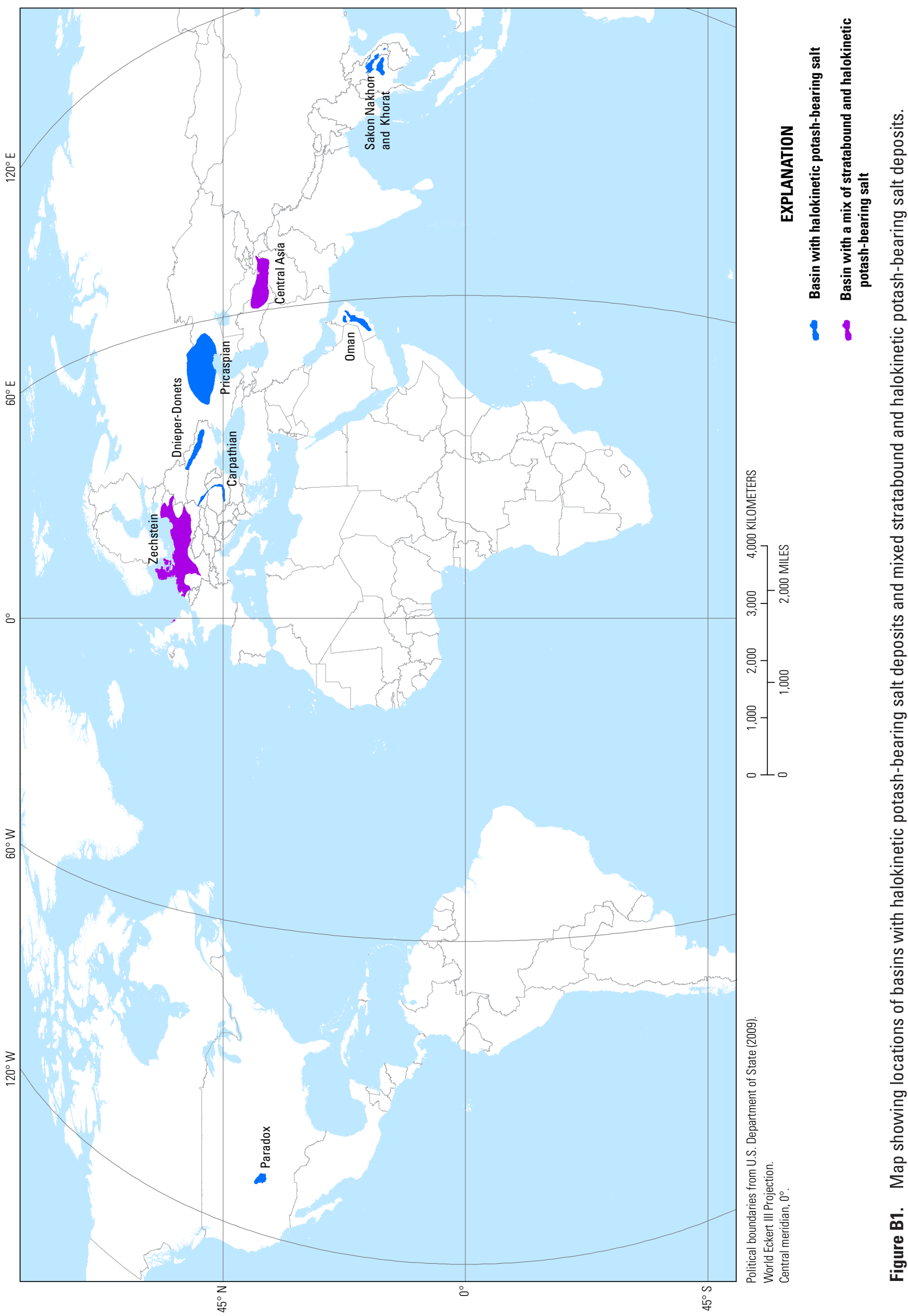


\section{Permissive Tract Delineation}

The fundamental unit for delineation of tracts permissive for potash-bearing bedded salt is an evaporite-bearing sedimentary basin that contains halite-dominated areas and evidence that evaporation reached the bittern stage. Evidence of potash mineralization includes reports of the presence of sylvite, carnallite, polyhalite, other potassium saline minerals or indirect evidence from downhole geophysical surveys.

Permissive tracts for halokinetic potash-bearing salt deposits are outlined by (1) selecting basins with known halokinetic salt; (2) restricting tract boundaries to areas likely underlain by halokinetic salt at depths of $3 \mathrm{~km}$ or less; (3) if possible, using drill hole or other information to limit tracts to areas underlain by potash-bearing salt; and (4) delineating specific salt structures likely to contain potash-bearing salt.

\section{Regional Geologic Attributes}

Halokinesis is most common in continental and oceanic rift basins, foreland basins, convergent basins, and transform basins where lateral compression or extension is active. Halokinesis may be initiated by such factors as (1) differential loading through rapid deposition of thick, overlying clastic sediments; (2) differential unloading resulting from listric block faulting during extensional rifting; (3) differential erosion of overlying sedimentary rocks; (4) rift basement block faulting; and (5) compressional or extensional regional tectonic activity (Al-Zoubi and ten Brink, 2001; Amor, 1999; Jarhani and others, 2007; Kityk, 1970).

\section{Depositional Systems}

In an evaporite basin, near-shore, shallow clastic facies rocks grade to carbonate-, then sulfate-, then halide-rich rocks towards the deeper, central parts of a basin. Central parts of an evaporite basin may have facies representing shallow water to deep water (Warren, 2006; Kendall, 2010; Schmalz, 1969). The resulting stratigraphic sequence begins with minor clastic red beds, followed by carbonate rocks, anhydrite or gypsum, salt, and ends with potash-bearing salt. Multiple episodes of evaporite mineral precipitation may be recorded in cyclic sequences of rock layers, with individual cyclic units ranging in thickness from a few centimeters to hundreds of meters. During halokinesis, the original depositional layering is partly to wholly disrupted by plastic flow, which may result in complex folding, discontinuous mineralization, or even loss of mineralization.

\section{Age Range and Age-Related Features}

Potash-bearing salt deposits are found in basins that are Neoproterozoic in age or younger (Goncharenko, 2006; Kovalevych and others, 2006; Warren, 2006, 2008; Zharkov, 1984, 2005). Half the world's known potash-containing basins are Middle and Late Devonian, Permian, or PaleogeneNeogene in age (Goncharenko, 2006).

Differences in deposit mineralogy likely reflect temporal changes in global seawater chemistry. During the Phanerozic, marine brine chemistry oscillated between $\mathrm{Na}-\mathrm{K}-\mathrm{Mg}-\mathrm{Ca}-\mathrm{Cl}$ and Na-K-Mg-Cl-SO 4 types (Hardie, 1990, 1996; Holland and others, 1996; Horita and others, 2002; Kovalevych and others, 1998; Ries, 2010; Warren, 2006). Magnesium sulfatepoor deposits dominated by sylvite and carnallite are derived from the Na-K-Mg-Ca-Cl brines. Magnesium-rich sulfate type deposits, with variable amounts of $\mathrm{K}$ - and $\mathrm{Mg}$-sulfate minerals, may form from Na-K-Mg-Cl-SO $\mathrm{S}_{4}$ brines. Local environmental conditions may be a significant factor in basin brine geochemistry.

\section{Local Geologic Attributes and Deposit Characteristics}

\section{Host Rocks}

Host rocks are evaporitic sedimentary rocks, such as rock salt, sylvinite, carnallitite, kainitite, hartsalz, anhydrite, and gypsum. Diapiric structures pierce overlying sediments, so any younger, originally overlying sedimentary rocks may appear to host the salt and potash mineralization.

\section{Impacts of Local Structures}

Halokinetic salt structures are commonly aligned over basement faults.

\section{Deposit Characteristics}

\section{Deposit Form and Dimensions}

The areal extent of salt diapirs ranges from a few to several hundred square kilometers. With a vertical extent ranging from a few hundred meters to more than 10 kilometers, salt volumes of diapirs are on the order of tens to hundreds of cubic kilometers. Potash forms only a small portion of an individual salt diapir. 
Mineralogy

Ore Mineralogy

Primary ore minerals include sylvite, carnallite, kainite, polyhalite, and langbeinite (table B1). These minerals most commonly are found as intergrowths with halite.

\section{Ore Assemblages}

The dominant ore assemblages contain sylvite and halite with minor $(<6$ weight percent) carnallite or carnallite plus halite and negligible amounts of sylvite. Some deposits may contain ore assemblages of kainite, langbeinite, polyhalite, kieserite and (or) bischofite mixed with halite and gypsum or anhydrite.

\section{Gangue Mineralogy}

Gangue minerals include halite, clay minerals, dolomite, anhydrite, gypsum, bischofite, epsomite, tachyhydrite, leonite, blödite, hexahydrite, vanthoffite, löweite, aphthitalite, picromerite, and borate minerals (table B1). Sonnenfeld (1991) noted the presence of halloysites, kaolinite, ironchlorite, magnesium-chlorites, montmorillonite, palygorskite, illite, sepiolite, and muscovite in evaporite basins.

Primary mineral zoning may consist of an outer or stratigraphically lower zone dominated by sulfates such as anhydrite or gypsum, changing to a halite-dominated zone, and culminating with an inner or upper zone containing halite plus potassium chloride or potassium sulfate minerals. Under certain conditions at the end of an evaporation sequence, some other bittern minerals, such as tachyhydrite or bischofite, may also be present and preserved. These minerals are highly soluble and are commonly no longer present in most of these deposits.

\section{Mineral Zoning}

Secondary zoning due to alteration may be pronounced along the flanks and apexes of salt structures.

\section{Ore Controls}

Ore controls peculiar to potash-bearing halokinetic salt structures include (1) zones of primary and secondary potash mineralization, (2) internal structure of the salt structures that affects thickness and location of the potash beds, and (3) depth to the potash ore. Halokinesis may bring potash-bearing salt into shallower depths, where they are more amenable to mining.

\section{Effects of Alteration}

As they rise to the surface, halokinetic potash-bearing salt structures interact with less saline brine and groundwater. Surface and groundwater may partially dissolve carnallite, removing magnesium chloride and leaving potassium chloride to form sylvite. In the upper portion of a salt structure, dissolution of salt minerals leaves insoluble materials such as gypsum, anhydrite, and clay that form a caprock that may be may be on the order of tens to a thousand meters thick (Warren, 2006).

Halokinesis can bring potash-bearing salt to the earth's surface or close to it, exposing the salt to surface weathering. In areas of extreme aridity, such as the Middle East, surface weathering is minimal, and salt and potash-bearing salt can exist on the surface.

\section{Exploration Guides}

\section{Geochemical Signatures}

Primary indicator elements of potash mineralization in rocks and groundwater include potassium, sodium, magnesium, bromine, chlorine, and sulfur as sulfate (Rogers, 2011). Exceptionally saline wells and saline spring water may be indicative of an evaporite sequence at depth, and have historically led to discoveries of concealed salt and potash deposits.

\section{Geophysical Signatures}

Seismic, gravity, and down hole gamma radiation surveys may be useful in the delineation of potash-bearing salt. The velocity contrast between salt and most other sedimentary rocks is sufficient that reflection seismic methods are used extensively to delineate salt structures and beds (Ratcliff and others, 1992; Ezersky, 2005). Salt is less dense than most enclosing sediments, so gravity surveys work well to identify and define salt structures (Benassi and others, 2006; Nettleton, 1968). High gamma radiation from the natural isotope $\mathrm{K}^{40}$ provides a measure of the potassium content of salt in drill hole logs (Garrett, 1996). In underground mines, ground penetrating radar may be used to define the structure of the salt diapir (Behlau and Mingerzahn, 2001; Kovin, 2011).

\section{Geomorphic and Physiographic Features}

Near-surface diapirs may be expressed as domal or collapse structures that are roughly circular topographic highs or lows. Lakes may form at the crest of near-surface salt structures owing to dissolution of the underlying evaporites.

\section{Other Exploration Guides}

The most readily detectable features of concealed salt structures that may contain potash include saline wells and springs. Except for drilling confirmation of potash, there are few sure indications of the presence of potash-bearing salt. Thick sections of halite, usually greater than $100 \mathrm{~m}$, are believed to be necessary prior to potash deposition (Harben and Kužvart, 1996), and this feature could be used in conjunction with other data to identify or rank the potash potential of basins with little exploration history. 
Table B1. Ore minerals and common accessory and gangue minerals in halokinetic potash-bearing salt deposits.

[Composition formulas from Back and Mandarino (2008)]

\begin{tabular}{|c|c|c|c|}
\hline Ore minerals & Composition & Other minerals & Composition \\
\hline Carnallite & $\mathrm{KMgCl}_{3} \cdot 6 \mathrm{H}_{2} \mathrm{O}$ & Aphthitalite & $(\mathrm{K}, \mathrm{Na})_{3} \mathrm{Na}\left(\mathrm{SO}_{4}\right)_{2}$ \\
\hline Kainite & $\mathrm{MgSO}_{4} \cdot \mathrm{KCl} \cdot 3 \mathrm{H}_{2} \mathrm{O}$ & Anhydrite & $\mathrm{CaSO}_{4}$ \\
\hline Langbeinite & $\mathrm{K}_{2} \mathrm{Mg}_{2}\left(\mathrm{SO}_{4}\right)_{3}$ & Bischofite & $\mathrm{MgCl} \cdot 6 \mathrm{H}_{2} \mathrm{O}$ \\
\hline Polyhalite & $\mathrm{K}_{2} \mathrm{Ca}_{2} \mathrm{Mg}\left(\mathrm{SO}_{4}\right)_{4} \cdot 2 \mathrm{H}_{2} \mathrm{O}$ & Blödite & $\mathrm{Na}_{2} \mathrm{Mg}\left(\mathrm{SO}_{4}\right)_{2} \cdot 4 \mathrm{H}_{2} \mathrm{O}$ \\
\hline \multirow[t]{22}{*}{ Sylvite } & $\mathrm{KCl}$ & Boracite & $\mathrm{Mg}_{7} \mathrm{~B}_{7} \mathrm{O}_{13} \mathrm{Cl}$ \\
\hline & & Dolomite & $\mathrm{CaMg}\left(\mathrm{CO}_{3}\right)_{2}$ \\
\hline & & Epsomite & $\mathrm{MgSO}_{4} \cdot 7 \mathrm{H}_{2} \mathrm{O}$ \\
\hline & & Gypsum & $\mathrm{CaSO}_{4} \cdot 2 \mathrm{H}_{2} \mathrm{O}$ \\
\hline & & Halloysite & $\mathrm{Al}_{2} \mathrm{Si}_{2} \mathrm{O}_{5}(\mathrm{OH})_{4}$ \\
\hline & & Halite & $\mathrm{NaCl}$ \\
\hline & & Hexahydrite & $\mathrm{MgSO}_{4} \cdot 6 \mathrm{H}_{2} \mathrm{O}$ \\
\hline & & Hydroboracite & $\mathrm{CaMgB}_{6} \mathrm{O}_{8}(\mathrm{OH})_{6} \cdot 3 \mathrm{H}_{2} \mathrm{O}$ \\
\hline & & Inderite & $\mathrm{Al}_{2} \mathrm{Si}_{2} \mathrm{O}_{5}(\mathrm{OH})_{4}$ \\
\hline & & Kaolinite & $\mathrm{Al}_{2} \mathrm{Si}_{2} \mathrm{O}_{5}(\mathrm{OH})_{4}$ \\
\hline & & Kieserite & $\mathrm{MgSO}_{4} \cdot \mathrm{H}_{2} \mathrm{O}$ \\
\hline & & Kurnakovite & $\mathrm{K}_{2} \mathrm{Mg}\left(\mathrm{SO}_{4}\right)_{2} \cdot 4 \mathrm{H}_{2} \mathrm{O}$ \\
\hline & & Leonite & $\mathrm{Na}_{12} \mathrm{Mg}_{7}\left(\mathrm{SO}_{4}\right)_{13} \cdot 15 \mathrm{H}_{2} \mathrm{O}$ \\
\hline & & Löweite & $(\mathrm{Na}, \mathrm{Ca})_{0.3}(\mathrm{Al}, \mathrm{Mg})_{2} \mathrm{Si}_{4} \mathrm{O}_{10}(\mathrm{OH})_{2} \bullet \mathrm{nH}_{2} \mathrm{O}$ \\
\hline & & Lüneburgite & $\mathrm{Mg}_{3} \mathrm{~B}_{2}\left(\mathrm{PO}_{4}\right)_{2}(\mathrm{OH})_{6} \cdot 6 \mathrm{H}_{2} \mathrm{O}$ \\
\hline & & Montmorillonite & $(\mathrm{Mg}, \mathrm{Al})_{2} \mathrm{Si}_{4} \mathrm{O}_{10}(\mathrm{OH}) \bullet 4 \mathrm{H}_{2} \mathrm{O}$ \\
\hline & & Palygorskite & $\mathrm{K}_{2} \mathrm{Mg}\left(\mathrm{SO}_{4}\right)_{2} \cdot 6 \mathrm{H}_{2} \mathrm{O}$ \\
\hline & & Picromerite & $\mathrm{Mg}_{4} \mathrm{Si}_{6} \mathrm{O}_{15}(\mathrm{OH})_{2} \cdot 6 \mathrm{H}_{2} \mathrm{O}$ \\
\hline & & Sepiolite & $\mathrm{CaMgCl}_{6} \cdot 12 \mathrm{H}_{2} \mathrm{O}$ \\
\hline & & Tachyhydrite & $\mathrm{Na}_{6} \mathrm{Mg}\left(\mathrm{SO}_{4}\right)_{4}$ \\
\hline & & Vanthoffite & $\mathrm{Na}_{6} \mathrm{Mg}\left(\mathrm{SO}_{4}\right)_{4}$ \\
\hline & & Volkovskite & $\mathrm{KCa}_{4} \mathrm{~B}_{22} \mathrm{O}_{32}(\mathrm{OH}) 10 \mathrm{Cl} \cdot 4 \mathrm{H}_{2} \mathrm{O}$ \\
\hline
\end{tabular}




\section{Typical Grade and Tonnage}

Tonnages of these deposits are smaller on average than stratabound potash-bearing salt deposits. However, some of the deposits have reported resources of as much 6-10 billion metric tons in some unusually large and complex salt structures. Grades are highly variable, but commonly average less than 20 percent $\mathrm{K}_{2} \mathrm{O}$.

\section{References Cited}

Al-Zoubi, Abdallah, and ten Brink, U.S., 2001, Salt diapirs in the Dead Sea basin and their relationship to Quaternary extensional tectonics: Marine and Petroleum Geology, v. 18, no. 7, p. 779-797.

Amor, H., 1999, Halokinesis and structural evolution of the major features in eastern and southern Tunisian Atlas: Tectonophysics, v. 306, no. 1, p. 79-95.

Back, Malcolm, and Mandarino, J.A., 2008, Fleischers glossary of mineral species 2008: Mineralogical Record, Inc., $346 \mathrm{p}$.

Behlau, J., and Minzerzahn, G., 2001, Geological and tectonic investigations in the former Morsleben salt mine (Germany) as a basis for the safety assessment of a radioactive waste repository: Engineering Geology, v. 61, p. 83-97.

Benassi, R., Jallouli, C., Hammami, M., and Turki, M.M., 2006, The structure of Jebel El Mourra, Tunisia-A diapiric structure causing a positive gravity anomaly: Terra Nova, v. 18 , p. 432-439.

Ezersky, M., 2005, The seismic velocities of the Dead Sea salt applied to the sinkhole problem: Journal of Applied Geophysics, v. 58, no. 1, p. 45-58.

Garrett, D.E., 1996, Potash-Deposits, processing, properties and uses: New York, Chapman \& Hall, 734 p.

Goncharenko, O.P., 2006, Potassic salts in Phanerozoic evaporite basins and specific features of salt deposition at the final stages of halogenesis: Lithology and Mineral Resources, v. 41, no. 4, p. $378-388$.

Harben, P.W., and Kužvart, M., 1996, Industrial minerals_-A global geology: London, Industrial Minerals Information Ltd., 462 p.

Hardie, L.A., 1990, The roles of rifting and hydrothermal $\mathrm{CaCl}_{2}$ brines in the origin of potash evaporites - An hypothesis: American Journal of Science, v. 290, no. 1, p. 43-106.
Hardie, L.A., 1996, Secular variation in seawater chemistryAn explanation for the coupled secular variation in the mineralogies of marine limestones and potash evaporites over the past 600 m.y.: Geology, v. 24, p. 279-283.

Holland, H.D., Horita, Juske, and Seyfried, W.E., Jr., 1996, On the secular variation in the composition of marine potash evaporates: Geology, v. 24, no. 11, p. 993-996.

Horita, Juske, Zimmerman, Heide, and Holland, H.D., 2002, Chemical evolution of seawater during the PhanerozoicImplications from the record of marine evaporites: Geochimica et Cosmochimica Acta, v. 66, no. 21, p. 3733-3756.

Jarhani, S., Callot, J.-P., Frizon de Lamotte, D., Letouzey, J., and Leturmy, P., 2007, The salt diapirs of the eastern Fars Province (Zagros, Iran) - A brief outline of their past and present, in Lacombe, O., Lavé, J., Roure, F., and Vergés, J., eds., Thrust belts and foreland basins: Berlin, Springer, $\mathrm{p}$. 289-308.

Kendall, A.C., 2010, Marine evaporites, in James, N.P., and Dalrymple, R.W., eds., Facies models 4: Geological Association of Canada, GEOtext 6, p. 505-540.

Kityk, V.I., 1970, Solianaia tektonika Dneprovskso-Donetskoi vpadiny [Salt tectonics of the Dnieper-Donets Depression]: Kiev, Akad. Nauk Ukrain. SSR, Inst. Geol. Nauk, 201 p.

Kovalevych, V.M., Marshall, T., Peryt, T.M., Petrychenko, O.Y., and Zhukova, S.A., 2006, Chemical composition of seawater in Neoproterozoic_-Results of fluid inclusion study of halite from Salt Range (Pakistan) and Amadeus Basin (Australia): Precambrian Research, v. 144, p. 39-51.

Kovalevych, V.M., Peryt, T.M., and Petrychenko, O.Y., 1998, Secular variation in seawater chemistry during the Phanerozoic as indicated by brine inclusions in halite: Journal of Geology, v. 106, p. 695-712.

Kovin, O., 2011, Mapping of evaporite deformation in a potash mine using ground penetration radar-Upper Kama deposit, Russia: Journal of Applied Geophysics, v. 74, p. 131-141.

Kyle, J.R., and Posey, H.H., 1991, Halokinesis, cap rock development, and salt dome mineral resources, in Melvin, J.L., ed., Evaporites, petroleum and mineral resources: New York, Elsevier, p. 413-474.

Long, K.R., 1992, Descriptive model of salt-dome sulfur and contained-sulfur model for salt-dome sulfur: U.S. Geological Survey Open-File Report 92-403, 8 p. 
Nettleton, L.L., 1968, Gravity anomalies over salt diapirs, northern Spain, in Mattox, R.B., Holser, W.T., Odé, H., McIntire, W.L., Short, N.M., Taylor, R.E., and Van Siclen, D.C., eds., Saline deposits: Geological Society of America Special Paper 88, p. 75-82.

Ratcliff, D.W., Gray, S.H., and Whitmore, N.D., Jr., 1992, Seismic imaging of salt structures in the Gulf of Mexico: The Leading Edge, v. 11, p. 15-31.

Raup, O.B., 1991, Descriptive model of salt domes; Deposit subtype-Diapiric salt structures, in Orris, G.J., and Bliss, J.D., Some industrial mineral deposit models - Descriptive deposit models: U.S. Geological Survey Open-File Report 91-11A, $73 \mathrm{p}$.

Ries, J.B., 2010, Review-Geological and experimental evidence for secular variation in seawater $\mathrm{Mg} / \mathrm{Ca}$ (calcitearagonite seas) and its effect on marine biological calcification: Biogeosciences, v. 7, p. 2795-2849.

Rogers, M.C., 2011, Saskatchewan descriptive mineral deposit models: Saskatchewan Ministry of Energy and Resources Open File Report 2011-57, 112 p.

Schmalz, R.F., 1969, Deep-water evaporite deposition-A genetic model: American Association of Petroleum Geologists Bulletin, v. 53, no. 4, p. 798-823.

Sonnenfeld, P., 1991, Evaporite basin analysis, in Force, E.R., Eidel, J.J., and Maynard, J.B., Sedimentary and diagenetic mineral deposits - A basin analysis approach to exploration: Reviews in Economic Geology Volume 5, p. 159-169.
U.S. Department of State, 2009, Small-scale digital international land boundaries (SSIB) - Lines, edition 10, and polygons, beta edition 1, in Boundaries and Sovereignty Encyclopedia (B.A.S.E.): U.S. Department of State, Office of the Geographer and Global Issues.

Warren, J.K., 2006, Evaporites-Sediments, resources and hydrocarbons: Berlin, Springer-Verlag, 1035 p.

Warren, J.K., 2008, Salt as sediment in the Central European Basin system as seen from a deep time perspective, in Littke, Ralf, Bayer, Ulf, and Gajewski, Dirk, eds., Dynamics of Complex Intracontinental Basins: Berlin, SpringerVerlag, p. 249-276.

Zharkov, M.A., 1984, Paleozoic salt bearing formations of the world: New York, Springer-Verlag, 427 p.

Zharkov, M.A., 2005, Evolyutsiya evaporitov v dokembrii v svyazi s preobrazovaniyami biosfery i khimicheskogo sostava mirovogo okeana; Stat'ya 1, Evapority arkheya i rannego proterozoya [Evolution of Precambrian evaporites, transformation of biosphere and the world oceans' chemical composition-Paper 1, Archean and Paleoproterozoic evaporites]: Stratigrafiya, Geologicheskaya Korrelyatsiya, v. 13, no. 2, p. 19-29. 


\title{
Appendix C. Glossary of Terms Used in the Description of Evaporites
}

\author{
By Mark D. Cocker ${ }^{1}$ and Greta J. Orris ${ }^{1}$
}

\begin{abstract}
Allochthonous salt Sheetlike salt bodies emplaced at stratigraphic levels above the autochthonous source layer. Allochthonous salt lies on stratigraphically younger strata; theoretically, allochthonous salt could overlie older strata, but such examples have not yet been reported (Jackson and Talbot, 1991).
\end{abstract}

Autochthonous salt Salt body resting on the original strata or surface on which it accumulated by evaporation (Jackson and Talbot, 1991).

Brachyanticline A short, broad anticline (Neuendorf and others, 2005). A short anticlinal fold of layers of rock having an oval map pattern. The layers of rock that form the brachyanticline slope away from the central portion of its crest on all sides. A brachyanticline is represented on a geological map in the form of concentric oval rings, with the older rocks located in the center; the rocks become progressively younger toward the periphery (Prokhorov, 1970-1979).

Cap rock [tectonics] In a salt dome, an impervious body of anhydrite and gypsum, with minor calcite and sometimes with sulfur, that overlies the salt body, or plug. It probably results from accumulation of the less soluble minerals of the salt body during leaching in the course of its ascent (Neuendorf and others, 2005).

Carnallite A primary potash ore mineral, $\mathrm{KMgCl}_{3} \cdot 6 \mathrm{H}_{2} \mathrm{O}$, which also is a source of magnesium in some deposits. Usually occurs as crystalline or granular masses. Mode of occurrence: occurs chiefly as a component of extensive thick sedimentary saline deposits, commonly associated with kieserite, halite, sylvite, and polyhalite (Roberts and others, 1974; Neuendorf and others, 2005).

Carnallitite A rock composed largely of a mixture of carnallite and halite (salt).

Cycle A kind of rhythmicity exhibited in many sedimentary sections owing to regularly alternating beds traceable over long distance, or a repetition of larger units that are referred to as sedimentary sequences or cycles. Rhythmic and cyclic sequences occur worldwide on various scales in presumably every environmental and stratigraphic system (Einsele, 2000).

Dewatering The expulsion of water from sediments during diagenesis or metamorphism. The water may have been present in the form of interstitial pore waters or water bound to hydrous minerals, such as certain clays or gypsum (Friedman and others, 1992, p.11; Neuendorf and others, 2005).
Diapir [structural geology] A dome or anticlinal fold in which the overlying rocks have been ruptured by the squeezing out of plastic core material. Diapirs in sedimentary strata usually contain cores of salt or shale (Neuendorf and others, 2005).

Evaporite A sedimentary rock composed primarily of minerals produced from a saline solution as a result of extensive or total evaporation of the solvent. Examples include gypsum, anhydrite, other diverse sulfates, halite (rock salt), primary dolomite, and various nitrates and borates (Neuendorf and others, 2005).

Gypsum A widely distributed mineral consisting of hydrated calcium sulfate, $\mathrm{CaSO}_{4} \cdot 2 \mathrm{H}_{2} \mathrm{O}$. Usually occurs as crystalline masses, fine to coarse granular; fibrous; pulverent; concretionary. Mode of occurrence: abundant and widespread, largest volumes in marine sedimentary (evaporite) deposits. Also occurs in sediments of saline lakes and playas, as efflorescence on certain soils, in the oxidized portions of ore deposits, and in deposits associated with volcanic activity (Roberts and others, 1974). It is the most common sulfate mineral, and is frequently associated with halite and anhydrite in evaporites, forming thick, extensive beds interstratified with limestone, shale, and clay (especially in rocks of Permian and Triassic age) (Neuendorf and others, 2005). It may alter to anhydrite under burial metamorphic conditions, releasing its water of hydration (Adams, 1970).

Halite An abundant evaporite mineral, $\mathrm{NaCl}$, most commonly interbedded or intergrown with various potash minerals. Usually occurs as crystalline masses, granular, and rarely columnar or stalactitic. Mode of occurrence: widespread, chiefly as extensive sedimentary deposits ranging from a few centimeters to more than several thousand meters in thickness; as efflorescence in playa deposits; and as a sublimation product in areas of volcanism (Roberts and others, 1974; Neuendorf and others, 2005).

Halokinesis (1) a class of salt tectonics in which salt flow is powered entirely by gravity in the absence of significant lateral tectonic forces (Jackson and Talbot, 1991). (2) The deformation of halite by flowage. Mechanisms cited for this process include gravity flow, tectonic thrusting, and diapirism (Kyle and Posey, 1991; Neuendorf and others, 2005).

Hartsalz Hard salt, typically a mixture of sylvinite and kieserite, with some anhydrite, found in the Stassfurt salt deposits (U.S. Bureau of Mines, 1996).

${ }^{1}$ U.S. Geological Survey, Tucson, Arizona, United States. 
Horse A miners' term for a barren mass of country rock occurring within a vein (Neuendorf and others, 2005).

Intracratonic basin A basin formed within the interior region of a continent, away from plate boundaries. It develops where there is subsidence of a portion of a craton, probably due to thermal subsidence of an unsuccessful rift (Neuendorf and others, 2005).

Rim syncline A fold having an arcuate or subcircular axial trace on the outer margin of a salt upwelling. Rim syncline is a nongenetic term, but in the context of salt tectonics a rim syncline typically results from salt withdrawal in the source layer. Peripheral sinks of sediments accumulate within rim synclines (Nettleton, 1968; Jackson and Talbot, 1991; Neuendorf and others, 2005).

Rock salt Coarsely crystalline halite occurring as a massive, fibrous, or granular aggregate, and constituting a nearly pure sedimentary rock that may occur in domes or plugs, or as extensive beds resulting from evaporation of saline water. It is frequently stained by iron or mixed with fine-grained sediments (Neuendorf and others, 2005).

Safety pillar A significant thickness, usually about $150 \mathrm{~m}$, of salt that is left in place below brine-saturated caprock and surrounding water-bearing strata to act as a seal in a diapiric salt structure (Heim and Potthoff, 1983).

Saline giant A term used to describe thick, basin-filling evaporite units; synonomous with mega-evaporites.

Mineralogies are dominated by halite and (or) anhydrite, along with varying amounts of carbonates and potash salts (Warren, 2006, 2010).

Salt A general term for naturally occurring sodium chloride, $\mathrm{NaCl}$ (see rock salt).

Salt anticline (1) A diapiric or piercement structure, like a salt dome, except that the salt core is linear rather than equidimensional, such as the salt anticlines in the Paradox basin of the central Colorado Plateau (Neuendorf and others, 2005); (2) Elongated upwelling of salt having concordant overburden (DeGolyer, 1925; Harrison and Bally, 1988; Jackson and Talbot, 1991).

Salt back A significant thickness of salt above the mining horizon maintained to ensure a water seal between mine openings and overlying strata that contain groundwater. Salt back thickness depends on mining method and nature of water saturation and rock competency in overlying beds (Holter, 1969).

Salt diapir A mass of salt that has flowed ductilely and appears to have discordantly pierced or intruded the overburden. In its broadest sense, "diapir" includes (1) lateral or vertical intrusion of any shape, (2) upwelling of buoyant or non-buoyant rock or magma, or (3) emplacement by passive piercement or by faulting of prekinematic overburden (Mrazec, 1907; Jackson and Talbot, 1991).
Salt dome (1) A diapir or piercement structure with a central, nearly equidimensional salt plug, generally $1-2 \mathrm{~km}$ or more in diameter, which has risen through enclosing sediments from a mother salt bed (source layer) $5 \mathrm{~km}$ to more than $10 \mathrm{~km}$ beneath the top of the plug. Many salt plugs have a cap rock of less soluble evaporite minerals, especially anhydrite. Enclosing sediments are commonly turned up and complexly faulted next to a salt plug, and these more permeable beds serve as reservoirs for oil and gas (U.S. Bureau of Mines, 1996); (2) An informal, general term for a domal upwelling comprising a salt core and its envelope of deformed overburden. The salt may or may not be discordant (Harris and Veatch, 1899; Jackson and Talbot, 1991).

Salt glacier Sheetlike extrusion of salt flowing from an exposed diapir and spreading subaqueously or subaerially (Jackson and Talbot, 1991).

Salt horse A dome-shaped barren zone generally consisting of halite that cross cuts potash horizons. Bedding is continuous through the halite, but is thinner than the potash horizons. Halite is believed to have replaced the potash horizon in the salt horse through upward movement of saline brines (Linn and Adams, 1963).

Salt pillow A subcircular upwelling of salt having concordant overburden (Jackson and Talbot, 1991).

Salt plug The salt core of a salt dome. It is nearly equidimensional, about $1-2 \mathrm{~km}$ in diameter, and has risen through the enclosing sediments from a mother salt bed (source layer) 5-10 km below (Neuendorf and others, 2005).

Salt solutioning A partial to complete dissolution of salts, commonly resulting in collapse of overlying strata, and is attributed to ascending or descending less saline water or brine (Holter, 1969).

Salt stock (synonym, salt plug) A pluglike salt diapir having subcircular planform. (Trusheim, 1957; Jackson and Talbot, 1991; Neuendorf and others, 2005).

Salt tectonics (synonym, halotectonics) Any tectonic deformation involving salt, or other evaporites, as a substratum or source layer; including halokinesis (Trusheim, 1957; Jackson and Talbot, 1986, 1991).

Salt wall An elongated upwelling of diapiric (discordant) salt, commonly forming sinuous, parallel rows (Trusheim, 1960; Jackson and Talbot, 1991).

Salt weld Surface or zone joining strata originally separated by autochthonous or allochthonous salt. The weld is a negative salt structure resulting from the complete or nearly complete removal of intervening salt. The weld can consist of brecciated, insoluble residue containing halite pseudomorphs, or of salt that is too thin to be resolved in reflection-seismic data. The weld is usually, but not always, marked by a structural discordance. Another distinctive feature of welds is a structural inversion above them (Jackson and Talbot, 1991). 
Salt withdrawal (synonym, salt expulsion) Mass transfer of salt over time without obvious change in salt area in cross section. Examples include salt migration from the flanks of a salt pillow into its core as it evolves into a diapir or the flow of salt along a salt wall into local culminations that evolve into salt stocks. (Jackson and Talbot, 1991; Neuendorf and others, 2005).

Source layer (synonym, mother salt) Layer supplying salt for the growth of salt structures; the source layer is a particular type of substratum (Jackson and Talbot, 1991).

Stratabound Said of a mineral deposit confined to a single stratigraphic unit (Neuendorf and others, 2005).

Substratum An underlying layer; in salt tectonics, substratum refers to the ductile layer below a brittle overburden and above the subsalt strata or basement. "Substratum" is a term more general than source layer; the substratum may or may not give rise to upwelling structures (Jackson and Talbot, 1991).

Subrosion (synonym, postburial dissolution) The process by which soluble rocks in the underground are dissolved by groundwater or water penetrating from the surface. Subrosion takes place where soluble rocks are not protected by a layer of impermeable rocks (Rauche and van der Klauw, 2011).

Subsalt strata Sedimentary unit immediately underlying salt (Jackson and Talbot, 1991).

Sylvite The mineral sylvite, $\mathrm{KCl}$, is the principal ore mineral of potassium. Usually in crystalline masses, compact to granular, as crusts, and columnar. Mode of occurrence: Occurs chiefly as extensive thick sedimentary deposits, typically associated with halite, gypsum, anhydrite, carnallite, polyhalite, kieserite, and kainite (Roberts and others, 1974; Neuendorf and others, 2005).

Sylvinite A mixture of halite and sylvite, mined as a potash ore; a rock that contains chiefly impure potassium chloride (Neuendorf and others, 2005).

Turtle-structure anticline Mounded strata between salt diapirs having a flat base and rounded crest over a local primary increase in sedimentary thickness; the anticline may or may not be cored by a low salt pillow. Two possible methods of formation: (1) the turtle structure forms between diapirs whose flanks subside because of regional extension or between salt structures evolving from pillows to diapirs (Trusheim, 1957; Neuendorf and others, 2005); (2) the turtle structure forms by structural inversion of a primary peripheral sink when salt is withdrawn from the margins of the peripheral sink by growing diapirs. The planform of turtle structures is typically highly irregular, depending on the number, location, and relative vigor of the diapirs flanking it (Trusheim, 1960; Jackson and Talbot, 1991).

\section{References Cited}

Adams, S.S., 1970, Ore controls, Carlsbad Potash District, Southeast New Mexico, in Rau, J.L., and Dellwig, L.F., Third Symposium on salt, volume 1: Cleveland, Ohio, Northern Ohio Geological Society, p. 246-257.

DeGolyer, E.L., 1925, Discovery of potash salts and fossil algae in Texas salt dome: American Association of Petroleum Geologists Bulletin, v. 9, no. 2, p. 348-349.

Einsele, G., 2000, Sedimentary basins - evolution, facies, and sediment budget: New York, Springer, 792 p.

Friedman, G.M., Sanders, J.E., and Kopaska-merkee, D.C., 1992, Principles of sedimentary deposits - stratigraphy and sedimentology: New York, MacMillan Publishing Company, $43 \mathrm{p}$.

Harris, G.D., and Veatch, A.C., 1899, A preliminary report on the geology of Louisiana: Baton Rouge, Geological Survey of Louisiana Report, 324 p.

Harrison, J.C., and Bally, A.W., 1988, Cross sections of the Devonian to Mississippian fold belt on Melville Island, Canadian Arctic Islands: Canadian Society of Petroleum Geologists, v. 36, p. 311-332.

Heim, W.A., and Pothoff, A.H., 1983, Potash mining in steep deposits (salt domes), in McKercher, R., ed., Potash '83: New York, Pergamon Press, p. 79-84.

Holter, M.E., 1969, The Middle Devonian Prairie Evaporite of Saskatchewan: Saskatchewan Department of Mineral Resources Report 123, 134 p.

Jackson, M.P.A., and Talbot, C.J., 1986, External shapes, strain rates, and dynamics of salt structures: Geological Society of America Bulletin, v. 97, p. 305-323.

Jackson, M.P.A., and Talbot, C.J., 1991, A glossary of salt tectonics: Texas Bureau of Economic Geology Geological Circular 91-4, $44 \mathrm{p}$.

Kyle, J.R., and Posey, H.H., 1991, Halokinesis, cap rock development, and salt dome mineral resources, in Melvin, J.L., ed., Evaporites, petroleum and mineral resources: New York, Elsevier, p. 413-474.

Linn, K.O., and Adams, S.S., 1963, Barren halite zones in potash deposits, Carlsbad, New Mexico, in Rau, J.L., ed., Second Symposium on Salt: Cleveland, Ohio, Northern Ohio Geological Society, p. 59-69.

Mrazec, L., 1907, Despre cute cu sîmbure de strapungere [On folds with piercing cores]: Romania, Buletinul Societatiide de ştiinţe, v. 16, p. 6-8. 
Nettleton, L.L., 1968, Gravity anomalies over salt diapirs, northern Spain, in Mattox, R.B., Holser, W.T., Odé, H., McIntire, W.L., Short, N.M., Taylor, R.E., and Van Siclen, D.C., eds., Saline deposits: Geological Society of America Special Paper 88, p. 75-82.

Neuendorf, K.K.E., Mehl, J.P., Jr., and Jackson, J.A., 2005, Glossary of Geology (5th ed.): Alexandria, Virginia, American Geological Institute, 799 p.

Prokhorov, A.M., ed., 1970-1979, The Great Soviet Encyclopedia: New York, Macmillan Inc., 31 volumes and 3 volumes of indexes.

Rauche, H., and van der Klauw, S., 2011, Technical report and resource report for the Danakhil potash deposit, Afar State, State/Ethiopia: Erfurt, Germany, ERCOPSPLAN Ingenieurgesellschaft, 128 p. plus appendixes.

Roberts, W.L., Rapp, Jr., G.R., and Weber, Julie, 1974, Encyclopedia of minerals: New York, Van Nostran Reinhold Company, 693 p.
Trusheim, Ferdinand, 1957, Über halokinese und ihre bedeutung für die strukturelle entwicklung Norddeutschlands [On halokinesis and its significance for the structural development of North Germany]: Zeitschrift für Deutsche Geologische Gesellschaft, v. 109, p. 111-151.

Trusheim, Ferdinand, 1960, Mechanism of salt migration in northern Germany: Bulletin of the American Association of Petroleum Geologists, v. 44, no. 9, p. 1519-1540.

U.S. Bureau of Mines, 1996, Dictionary of mining, mineral, and related terms: U.S. Bureau of Mines Report SP-96-1, CD-ROM.

Warren, J.K., 2006, Evaporites-Sediments, resources and hydrocarbons: Berlin, Springer-Verlag, 1035 p.

Warren, J.K., 2010, Evaporites through time-Tectonic, climatic, and eustatic controls in marine and nonmarine deposits: Earth-Science Reviews, v. 98, no. 3-4, p. 217-268. 


\title{
Appendix D. Abbreviations Used in the Potash Geodatabases
}

\author{
By Greta J. Orris', Mark D. Cocker', and Pamela Dunlap ${ }^{1}$
}

Table D1. List of abbreviations used in the potash geodatabases.

[COMECON, reserve classification used by the Eastern Bloc and other communist countries participating in the Council for Mutual Economic Assistance (Henley, 2004; Jakubiak and Smakowski, 1994)]

\begin{tabular}{lllll}
\hline \multicolumn{1}{c}{ Abbreviation } & \multicolumn{1}{c}{ Meaning } & & Abbreviation \\
\cline { 1 - 1 } A & reserve category (COMECON) & & lang & langbeinite \\
approx & reserve category (COMECON) & approximately & Mbr & meter \\
ave & average & meas & measured reserves \\
C1 & reserve category (COMECON) & min & mineable reserves \\
C2 & reserve category (COMECON) & Mt & million metric tons \\
car & carnallite & ND & not determined \\
Cm & centimeter & NL & not located \\
ESCAP & Economic and Social Commission for Asia & & PCS & Potash Corporation of Saskatchewan \\
& and the Pacific & estimated & poss & possible reserves/resource \\
est & formation & prob & probable reserves \\
Fm & geologic resource & prov & proven reserves \\
Geol & group & OMGG & Office of Military Government for Germany \\
Grp & indicated reserves & rec & recoverable reserves \\
ind & inferred reserves & res & resource \\
inf & insolubles & syl & sylvite \\
insol & kilometers & tot & total \\
km & & & \\
\hline
\end{tabular}

\section{References Cited}

Henley, S., 2004, Russian mineral reporting: London, Mining Journal, p. 18-21, accessed August 12, 2011, at http://www. mining-journal.com/focus/russian-mineral-reporting.

Jakubiak, Z., and Smakowski, T., 1994, Classification of mineral reserves in the former Comecon countries, in Whateley, M.K.G., and Harvey, P.K., eds., Mineral resource evaluation II-Methods and case histories: Geological Society of London Special Publication 79, p. 17-28. 


\title{
Appendix E. Digital Data Files
}

\author{
By Pamela Dunlap ${ }^{1}$
}

The digital data files released in this report are listed and briefly described in tables E1, E2, and E3. Spatial databases and associated files for use in Esri ArcGIS 10 software are packaged in the compressed archive file, PotashGIS.zip (table E1). Tabular data for use in Microsoft Excel 2010 are in PotashXL.zip (table E2). Spatial data for use in Google Earth are in PotashKML.zip (table E3). These compressed archive files are available on the Internet at http://dx.doi.gov/10.3133/ sir20105090S.

\section{References Cited}

U.S. Department of State, 2009, Small-scale digital international land boundaries (SSIB) — Lines, edition 10, and polygons, beta edition 1, in Boundaries and Sovereignty Encyclopedia (B.A.S.E.): U.S. Department of State, Office of the Geographer and Global Issues.

Table E1. List and description of spatial databases and associated files in the compressed archive file PotashGIS.zip.

\begin{tabular}{|c|c|}
\hline File name & File description \\
\hline USGS_Global_Potash.gdb & FGDB (ArcGIS 10) for potash deposits and permissive areas (tracts) \\
\hline state_dept_boundaries.gdb & FGDB (ArcGIS 9) for country boundaries (U.S. Department of State, 2009) \\
\hline \multicolumn{2}{|c|}{ FGDB elements (feature dataset, feature classes, tables, and relationship classes) in USGS_Global_Potash.gdb } \\
\hline Potash_Deposits & Feature class (points) for deposits and occurrences \\
\hline Potash_Tracts & Feature class (polygons) for tracts \\
\hline Potash_Deposits_ATTACH & Table of figures attached to the feature class Potash_Deposits \\
\hline Potash_Deposits_ATTACHREL & $\begin{array}{l}\text { Relationship class that manages the relationship between figures listed in table Potash } \\
\text { Deposits_ATTACH and the feature class Potash_Deposits (so that representative figures } \\
\text { can be viewed from within the ArcMap document Potash_Deposits_and_Tracts.mxd) }\end{array}$ \\
\hline Deposits_AllRefs & $\begin{array}{l}\text { Table of site names, their identifiers (Site_ID), and associated references cited in the } \\
\text { feature class Potash_Deposits }\end{array}$ \\
\hline Potash_Tracts_ATTACH & Table of figures attached to the feature class Potash_Tracts \\
\hline Potash_Tracts_ATTACHREL & $\begin{array}{l}\text { Relationship class that manages the relationship between figures listed in the table } \\
\text { Potash Tracts_ATTACH and the feature class Potash_Tracts (so that representative } \\
\text { figures can be viewed from within the ArcMap document Potash_Deposits_and_Tracts. } \\
m x d \text { ) }\end{array}$ \\
\hline Tracts_GeologyRefs & $\begin{array}{l}\text { Table of tract names, their coded identifiers (Coded_ID), and associated references cited } \\
\text { in the feature class Potash_Tracts }\end{array}$ \\
\hline
\end{tabular}

${ }^{1}$ U.S. Geological Survey, Tucson, Arizona, United States. 
Table E1. List and description of spatial databases and associated files in the compressed archive file PotashGIS.zip.-Continued

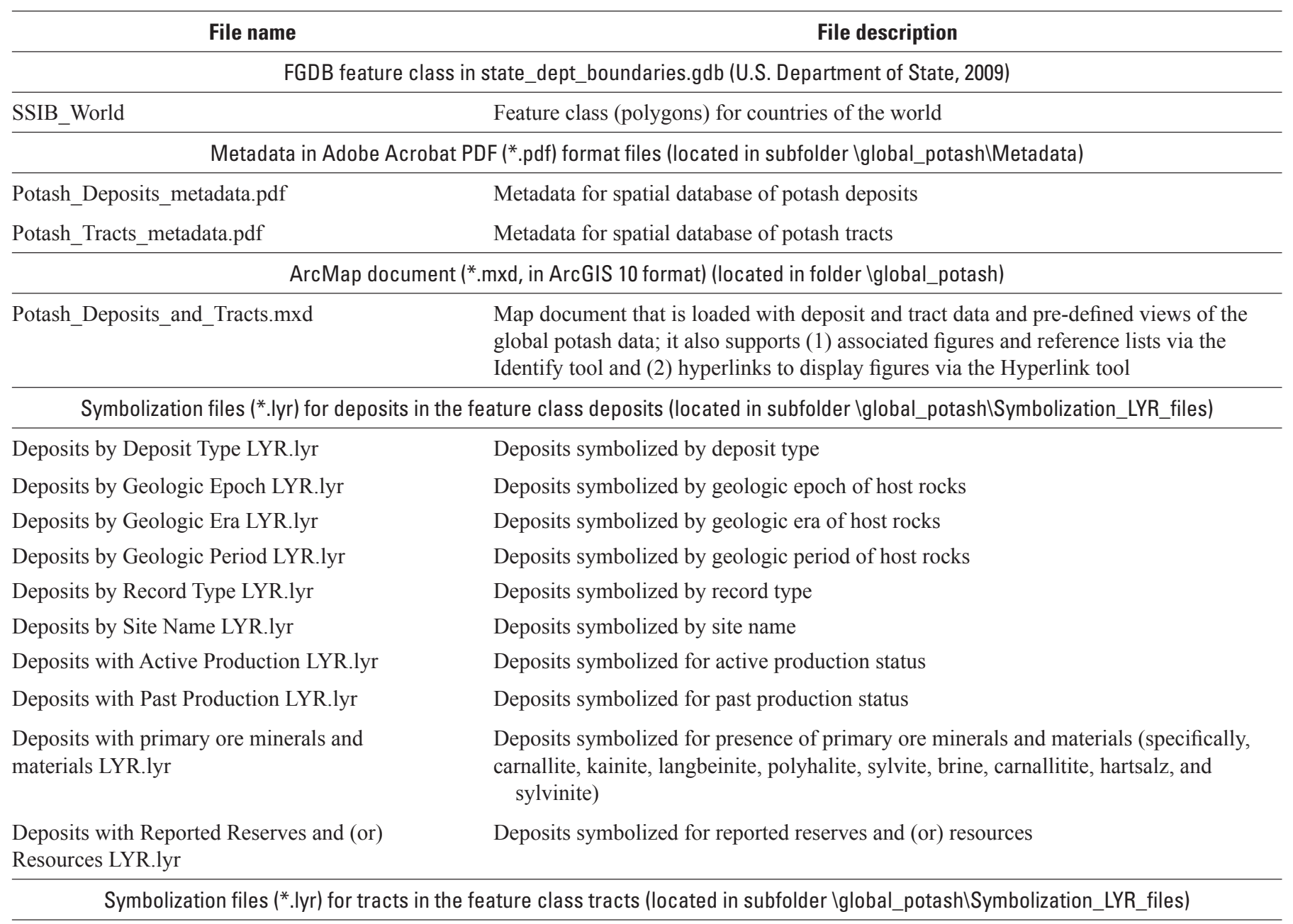

Tracts by Activity and Identified Resources LYR.lyr

Tracts by Basin Type LYR.lyr

Tracts by Deposit Type LYR.lyr

Tracts by Geologic Epoch LYR.lyr

Tracts by Geologic Era LYR.lyr

Tracts by Geologic Period LYR.lyr

Tracts by oldest age rocks LYR.lyr

Tracts by Resource Rank LYR.lyr

Tracts by Tectonic Setting LYR.lyr

Tracts by Tract Name LYR.lyr

Tracts by youngest age rocks LYR.lyr
Tracts symbolized by mining activity, exploration activity, and identified resources

Tracts symbolized by basin type

Tracts symbolized by deposit type

Tracts symbolized by geologic epoch of host rocks

Tracts symbolized by geologic era of host rocks

Tracts symbolized by geologic period of host rocks

Tracts symbolized by oldest age of host rocks

Tracts symbolized by qualitative resource rank

Tracts symbolized by tectonic setting

Tracts symbolized by name

Tracts symbolized by youngest age of host rocks Graphics files in Adobe PDF format (*.pdf) (located in subfolder Iglobal_potashlFigures)

AMUD_CrossSect_1fig.pdf

AMUD_More_thick_1fig.pdf

AMUD_StratSect_1fig.pdf

AMUD_StrOth_1fig.pdf

AMZ_more_SaltExtent_1fig.pdf

CAR_CrossSect_1fig.pdf
Cross section for Amu Darya area in Central Asia Jurassic Salt Basin

Thickness contours for Amu Darya area in Central Asia Jurassic Salt Basin

Stratigraphic section for Amu Darya area in Central Asia Jurassic Salt Basin

Other structures in Amu Darya area of Central Asia Jurassic Salt Basin

Estimated extent of Nova Olinda salt within the Amazonas tract

Cross section for Carpathians area 
Table E1. List and description of spatial databases and associated files in the compressed archive file PotashGIS.zip.—Continued

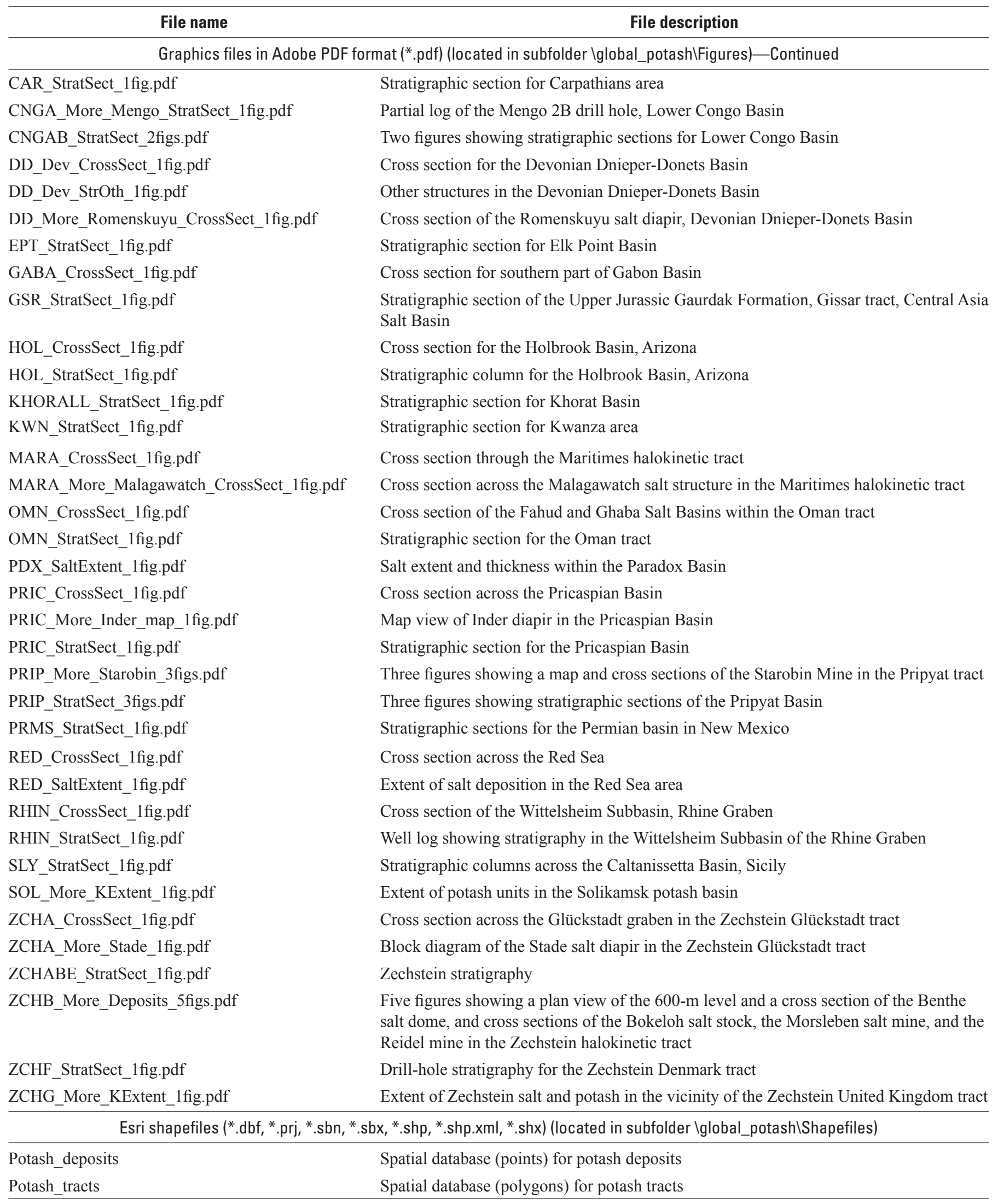


Table E2. List and description of tabular data files in the compressed archive PotashXL.zip.

\begin{tabular}{ll}
\hline \multicolumn{1}{c}{ File name } & \multicolumn{1}{c}{ File description } \\
\hline $\begin{array}{l}\text { Potash_deposits.xlsx } \\
\text { Potash_tracts.xlsx }\end{array}$ & Descriptive data for potash deposits \\
& Descriptive data for potash tracts \\
\hline
\end{tabular}

Table E3. List and description of spatial data and associated files in the compressed archive PotashKML.zip.

\begin{tabular}{|c|c|}
\hline File name & File description \\
\hline \multicolumn{2}{|c|}{$\begin{array}{l}\text { Spatial and descriptive data in keyhole markup language file format } \\
\left({ }^{*} . \mathrm{kml}\right) \text { for use in Google Earth (located in subfolder }(K M L \text { files) }\end{array}$} \\
\hline Potash deposits.kml & Potash deposits \\
\hline Potash tracts.kml & Potash tracts \\
\hline \multicolumn{2}{|c|}{ Image files (.gif) (located in subfolder IKML files) } \\
\hline c_168_USGS.gif & USGS logo \\
\hline sm_key_color_green.gif & USGS banner \\
\hline
\end{tabular}




\title{
Appendix F. GIS Quick Start
}

\author{
By Pamela Dunlap ${ }^{1}$
}

The spatial data files released in this report are designed for optimum use in ArcGIS version 10 or higher, Esri geographic information system (GIS) software. Data are packaged in the compressed archive file, PotashGIS.zip, which is available on the Internet at http://dx.doi.gov/10.3133/ sir20105090S.

Begin by extracting the data files from the file PotashGIS.zip into the folder of your choice. To view maps in ArcGIS 10, navigate to the folder named \global_potash and double-click on the map document file named Potash Deposits_and_Tracts.mxd. A map of the world will appear along with a Table of Contents window. Permissive tracts are shown in red on the map; those deposits with active production are shown as dark blue squares, and all deposits and occurrences are shown as black circles. Note that, in the Table of Contents window, boxes for the map layers "Sites with Active Production," "Deposits and Occurrences," "Permissive Tracts" and "SSIB_World" are checked; thus, these features are visible in the map window.

\section{Regional Map Views}

Bookmarks were created to enable viewing data either by continent or for the whole world. Click "Bookmarks" in the main menu bar and select the desired bookmark from the dropdown list. One may create additional bookmarks, if desired, for other areas of interest by panning or zooming to the area, selecting "Bookmarks," and choosing "Create."

\section{Symbolized Maps for Potash Deposits and Occurrences}

Maps of deposits and occurrences symbolized with various attributes may be viewed only at a map scale of $1: 50,000,000$ or larger (for example, 1:2,000,000). These maps are listed under the group layer "Deposit map legends" in the Table of Contents (TOC) window. To view the list of various maps and their legends, expand the group layer "Deposit map legends" (click on the plus (+) symbol in the small box at left of map name), and expand each map layer.

To view a particular map, check the box for the group layer "Deposit map legends," check the box for the desired map layer, uncheck all map layers listed above it in the TOC, and make sure the map scale is set to $1: 50,000,000$ or larger.

\footnotetext{
${ }^{1}$ U.S. Geological Survey, Tucson, Arizona, United States.
}

\section{Symbolized Maps for Permissive Tracts}

Maps of permissive tracts symbolized for various attributes may be viewed at all map scales. These maps are listed under the group layer "Tract map legends" in the TOC window. To view the list of various maps and their legends, expand the group layer "Tract map legends" (click on the plus $(+)$ symbol in the small box at left of map name), and expand each map layer.

To view a particular map, check the box for the group layer "Tract map legends," check the box for the desired map layer, and uncheck all map layers listed above it in the TOC.

\section{Descriptive Data and Source References}

To view a list of descriptive information on a site-by-site or tract-by-tract basis, use the Identify tool.

1. Check the box for "Deposits and Occurrences" or "Permissive Tracts" in the TOC window.

2. Right-click on either "Deposits and Occurrences" or "Permissive Tracts," choose "Selection" and then choose "Make This The Only Selectable Layer."

3. Click the Identify tool (icon with blue ball marked by a white lower-case " $\mathrm{i}$ " located on the Tools toolbar).

4. Click on a feature in the map view. An Identify window will appear; click the down arrow at the right end of the box for "Identify from" (at the top of the window) and set it to $<$ Selectable layers $>$. Close the Identify window, and click again on the desired feature. Now the Identify window displays information for the selected feature in a data window (which contains a grid with a column for "Field" and another for "Value").

5. If multiple choices appear in the hierarchical listing, click on the name of the desired feature.

6. The list of items in the data window provides all the attribute values for the selected feature. If figures illustrating further geologic information exist, a paperclip icon for attachments will appear just above the grid of field names and attribute values; in addition, a yellow lightning bolt icon will appear at the right margin of the cell(s) with entries for figures (they are listed in the column "Value" near the bottom of the grid). Click on either the paperclip icon or a cell with a lightning bolt to view these figures. 
7. References for sources of information can also be viewed in the "Identify" window. Expand the hierarchical listing for the feature and also for the subheading "Source Reference" (or "Source Reference(s):" for tracts), and then click on the nested feature names to view source references in the data window. Click on the value for the field "Web_link" to view the source reference on the Web.

\section{Figures}

Figures portraying additional geologic information are included for viewing within the ArcMap document via either the Identify or the Hyperlink tool. To view figures using the Identify tool, follow steps 1 through 6 in the above section. Note that one file or attachment may contain more than one figure.

Another way to view figures is to invoke the Hyperlink tool (yellow lightning bolt icon on the Tools toolbar). Zoom in to a scale of 1:50,000,000 or larger (for example, $1: 20,000,000)$ and click the lightning bolt pointer on any tract outlined in dark blue. Only tracts outlined in dark blue, and deposits marked by small, dark blue filled dots, have hyperlinked figures. Make sure to turn off all deposit map layers except for the layer "Deposits and Occurrences" to see the blue dots that identify deposits with hyperlinked figure(s); few figures are hyperlinked to deposits.

\section{Tips}

If you have ArcGIS 10 and cannot view the complete metadata in ArcCatalog, help is available from the Esri Web site at http://help.arcgis.com/en/arcgisdesktop/10.0/help/index. $\mathrm{html} \# / / 003 \mathrm{t} 00000031000000$. The first part of "Creating and Managing FGDC metadata" provides directions and insights to both configuring ArcGIS 10 for FGDC metadata and viewing an item's complete metadata. The following steps provided by Esri apply:

1. Open the Options dialog box for your ArcGIS Desktop application.

- In ArcMap, click Customize > ArcMap Options.

- In ArcCatalog, click Customize > ArcCatalog Options.

The Options dialog box appears.

2. Click the Metadata tab.

3. Click FGDC CSDGM Metadata in the Metadata Style list.

\section{Click OK.}

Note: If you're using the Description tab when you choose a new metadata style, you won't immediately see the results of this change. Click another tab in ArcCatalog or the Item Description window, then click the Description tab again for the new metadata style to take effect. 
Menlo Park Publishing Service Center, California

Manuscript approved for publication, July 21, 2014

Edited by Sarah E. Nagorsen and Chet Zenone

Layout and design by Sharon L. Wahlstrom 


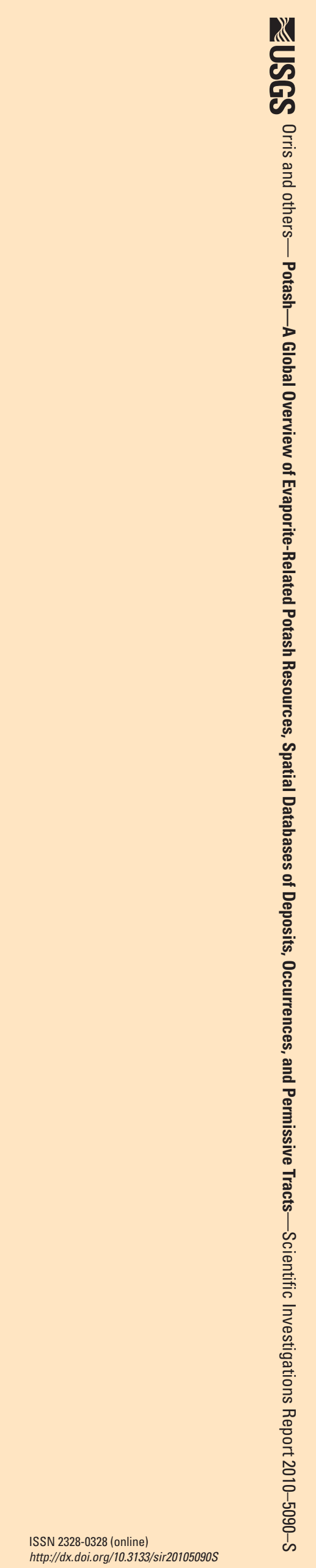

